\title{
52. VARIABILITY OF CENOZOIC NORWEGIAN-GREENLAND SEA PALEOCEANOGRAPHY AND NORTHERN HEMISPHERE PALEOCLIMATE
}

\author{
Synthesis of Paleoenvironmental Studies of ODP Leg 104, Vøring Plateau, \\ Norwegian Continental Margin ${ }^{1}$
}

\author{
Jörn Thiede, ${ }^{2}$ Olav Eldholm, ${ }^{3}$ and Elliott Taylor ${ }^{4,5}$
}

\begin{abstract}
The three drill sites of ODP Leg 104 (642-644) in the Norwegian Sea provided data to reconstruct the depositional paleoenvironment for the past 55 m.y. The three drill sites penetrated Paleogene and younger rocks and deposits on the Vøring Plateau, but only upper Neogene and Quaternary sediments in the Vøring Basin. The Neogene and Quaternary parts of the sedimentary sections can be correlated stratigraphically in detail to define gradients that existed between surface- and bottom-water properties and the influx of sedimentary components to this segment of the Norwegian continental margin.

The Neogene and Quaternary deposits consist predominantly of fine- to medium-grained biogenic and terrigenous hemipelagic deposits that have been dated and correlated by a diversity of pelagic microfossil groups, by magnetic methods, and by other stratigraphic tools. The sites are lithologically subdivided into an older Neogene section composed of predominantly siliceous biogenic oozes (Sites 643 and 642), a transitional facies of upper Miocene and Pliocene sediments of alternating calcareous and siliceous ooze, and an upper Pliocene and Pleistocene sequence of glacialinterglacial mainly terrigenous deposits. The pelagic faunas and floras have many endemic characteristics from the $\mathrm{Pa}$ leogene and lower Neogene, whereas those of the upper Neogene and Quaternary can be correlated with pelagic floras and faunas from the North Atlantic basins. Floras with Pacific affinities appear just above the Miocene/Pliocene boundary and are interpreted to date the early evolution of the East Greenland Current system.

Paleoclimatic evidence suggests that the subaerial central Vøring Plateau was covered by dense vegetation growing in a moist and damp climate generating lateritic soils on the volcanic floor during the early Paleogene. The central Vøring Plateau subsided since that time to its present intermediate depth, whereas the foot region of the Vøring Plateau has been located in intermediate and deep waters since its formation. During Eocene and Oligocene the warm climate persisted, though it was less moist than previously. Warm and damp conditions continued into the early Miocene but, during the latest early Miocene, the climate changed from warm to temperate. Clay assemblages indicate a progressive cooling to temperate conditions during the middle to late Miocene. From the latest Miocene through the Pliocene/Pleistocene the climate progressively entered its glacial mode; during the past $2.6 \mathrm{~m} . \mathrm{y}$. it was characterized by alternating glacial/interglacial climatic episodes.

Site 643 , located near the western boundary of the Norwegian Current and Site 644 near its eastern boundary, provide a record of that current and influxes of shelf waters. After subsidence of the Vøring Plateau, a continuous, pelagic, fully marine, depositional environment existed for the Eocene through Quaternary at Site 643 and the lower Eocene and the Neogene through Quaternary at Site 642. The pelagic faunas and floras suggest that the surface water stayed relatively warm, at least temperate, until the middle Miocene when intensive cooling began; but the first indicators of cold waters and of an intermittent modest ice cover first appeared at about $5.5 \mathrm{Ma}$ (based on ice-rafting). Since that time the surface waters have remained cool to temperate, being interrupted at times by incursions of more temperate waters. Major ice covers occurred at $2.6 \mathrm{Ma}$ and approximately $1.2 \mathrm{Ma}$. The entire time span with glacial surface waters present was characterized by continuous flux of ice-rafted, coarse, terrigenous material to the Vøring Plateau with apparently no major, long-lasting interruption of ice-free conditions. The intensity of the ice rafting has fluctuated widely and it is obvious from their fluxes that the iceberg production was highest during the Brunhes epoch.

The bottom waters showed a distinct response to the evolution of the surface waters. A poorly oxygenated depositional environment that led to relatively high concentrations of organic carbon persisted throughout the entire early part of the Neogene and into the middle Pliocene. Since then glacial/interglacial climatic fluctuations can be documented by means of the distinctive horizons of interglacial sediment alternating with enrichments of ice-rafted material. At that time bottom waters fluctuated between an almost stagnant, quiet, short-lived mode and a mode of rapid deepwater renewal resulting in oxygenation and intensive bioturbation of the surface sediments.
\end{abstract}

\footnotetext{
${ }^{1}$ Eldholm, O., Thiede, J., Taylor, E., et al., 1989. Proc. ODP, Sci. Results, 104: College Station, TX (Ocean Drilling Program).

2 GEOMAR, Forschungszentrum für Marine Geowissenschaften, Wischhofstrasse 1-3, D-2300 Kiel 14, Federal Repubic of Germany.

${ }^{3}$ Department of Geology, University of Oslo, N-0316 Oslo 3, Norway.

4 Ocean Drilling Program, Texas A\&M University, 1000 Discovery Drive, College Station, TX 77840 .

5 Current address: School of Oceanography, University of Washington, WB10, Seattle, WA 98195 .
}

\section{INTRODUCTION}

One of the most exciting, but also mysterious, themes of earth history comprises the Cenozoic change from the equable late Mesozoic and early Cenozoic temperate global climates to the mid- and late Cenozoic glacial/interglacial mode. At different times, this change drastically affected the polar and subpolar regions of both hemispheres, creating large continental ice 
sheets and a seasonally highly variable cover of sea ice (pack ice) in the adjacent ocean. Attempts to explain this climatic shift have employed global tectonic processes as well as changes in the amount of radiation reaching the earth's surface. However, the poor timing of the observational data and difficulties in understanding the casual relationship of the processes have prevented clarification of the Cenozoic climate of the polar regions.

In this paper paleoenvironmental observations and data from the Leg 104 Ocean Drilling Program (ODP) drill sites on the Vøring Plateau (Fig. 1) are synthesized in an attempt to describe the main evolution of the Northern Hemisphere Cenozoic climate. The tectonic and magmatic history of the Vøring margin is addressed in an accompanying synthesis by Eldholm, Thiede, and Taylor (this volume). The drilling program of Leg 104 was particularly interesting for paleoenvironmental purposes because:
1. The Norwegian-Greenland Sea is known to have experienced very fast and extreme temperature changes (Fig. 2) between interglacials and glacial maxima (Kellogg, 1976), and the Norwegian Current is one of the climatically most sensitive oceanic current regime of the world.

2. The Norwegian Current advects heat from the temperate main North Atlantic Basin to the subpolar Norwegian-Greenland Sea (Fig. 3), creating the moderate northwest European climate.

3. The bottom-water properties and renewal in the Greenland Sea initiate transport of cold and dense bottom water across the Greenland-Scotland Ridge (Meincke, 1983; Aagard, Swift and Carmack, 1985) from where it can be traced throughout the world ocean.

4. The stratified Cenozoic pelagic sediment cover of the Vøring Plateau (Eldholm, Thiede, and Taylor, 1987; Eldholm, Thiede, Taylor, et al., 1987; and this volume) was expected to

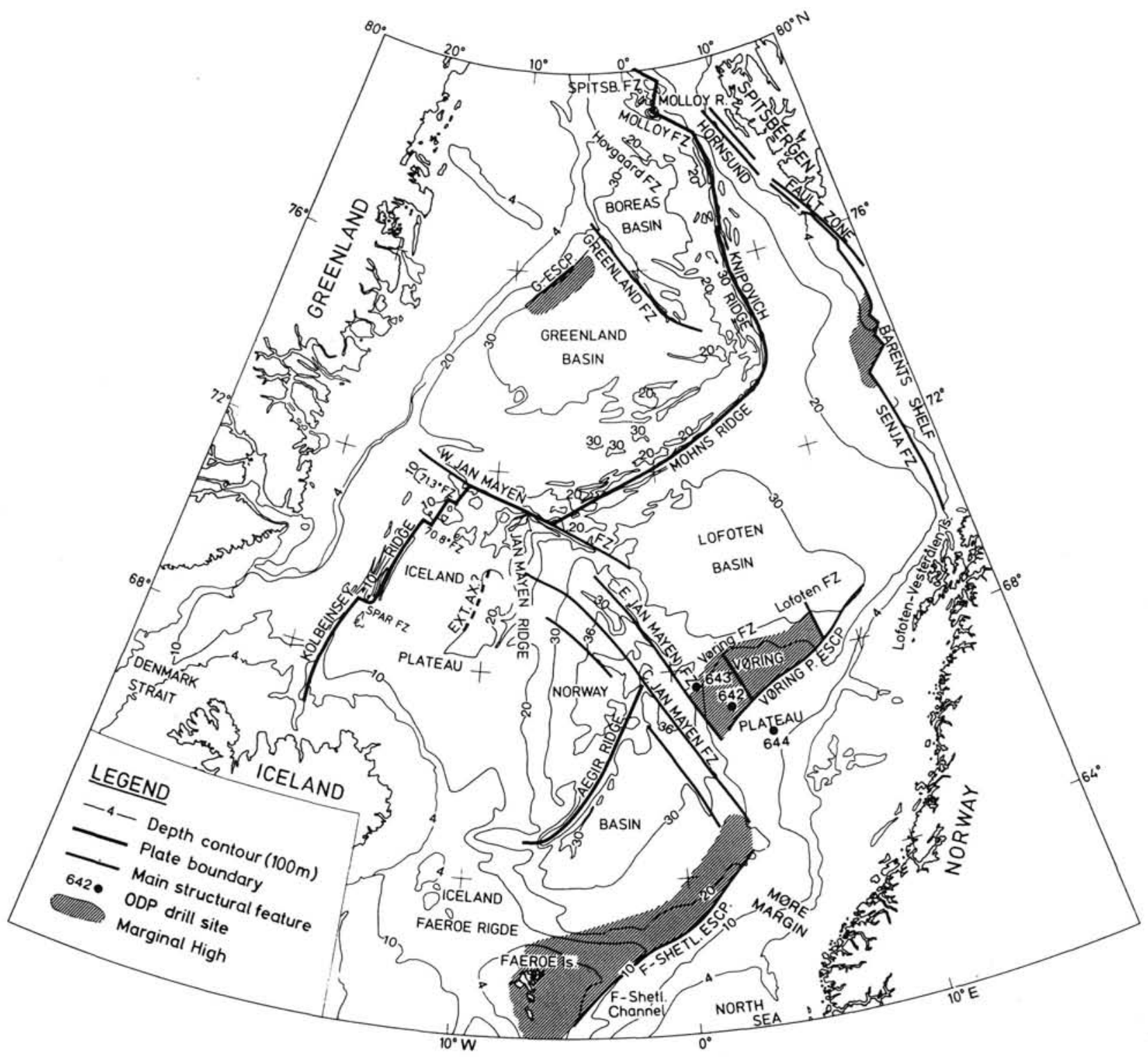

Figure 1. Norwegian-Greenland Sea bathymetry and main structural elements (Eldholm et al., 1989). 


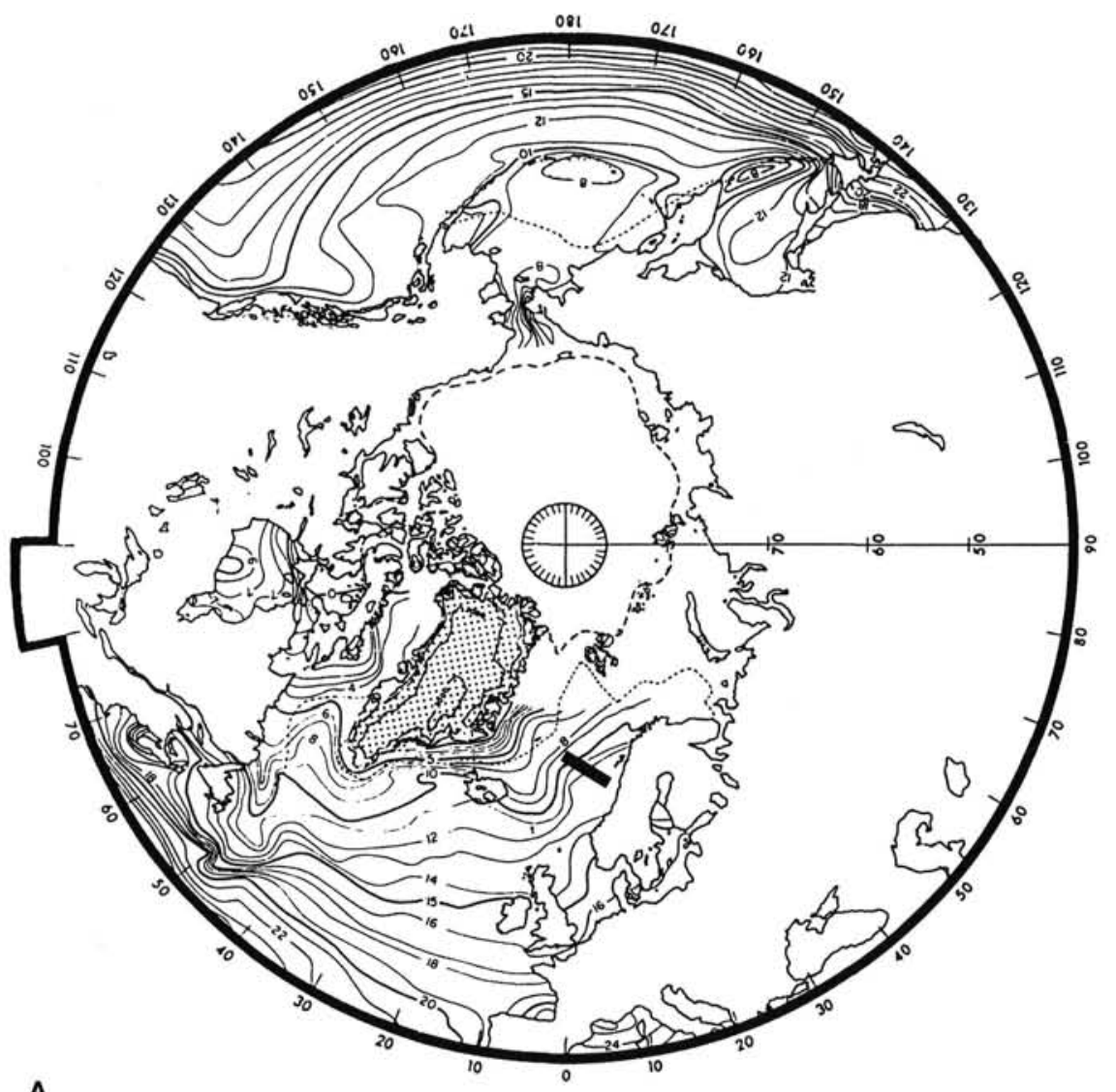

A

Figure 2. Northern Hemisphere sea-surface temperatures and ice distribution. (A) present situation, (B) last glacial maximum (18 Ka) (CLIMAP, 1981 ). Black bars mark ODP Leg 104 paleoenvironmental transect in the Norwegian Sea.

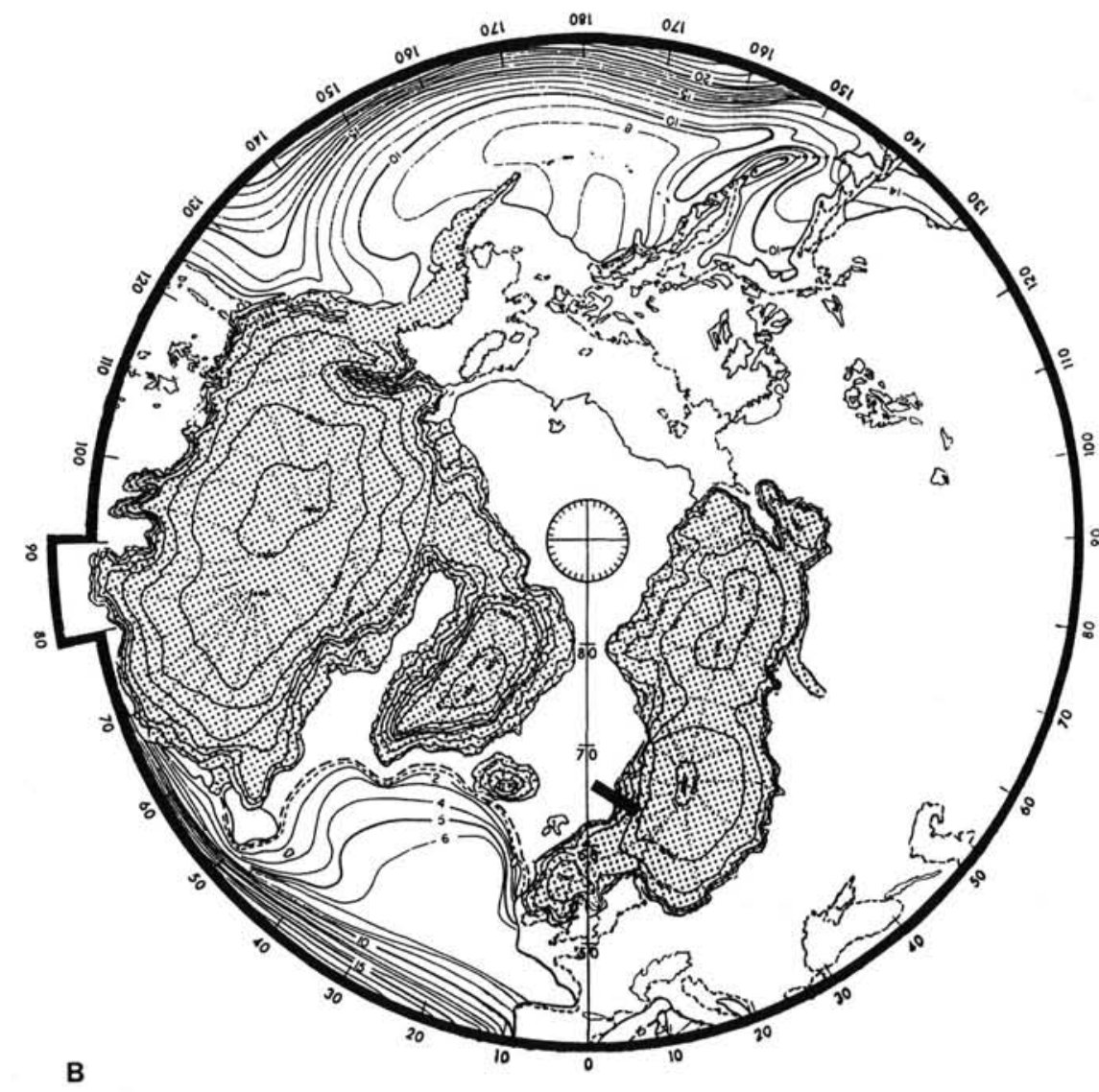

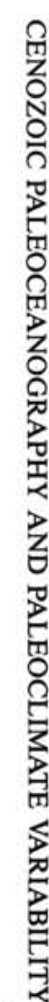




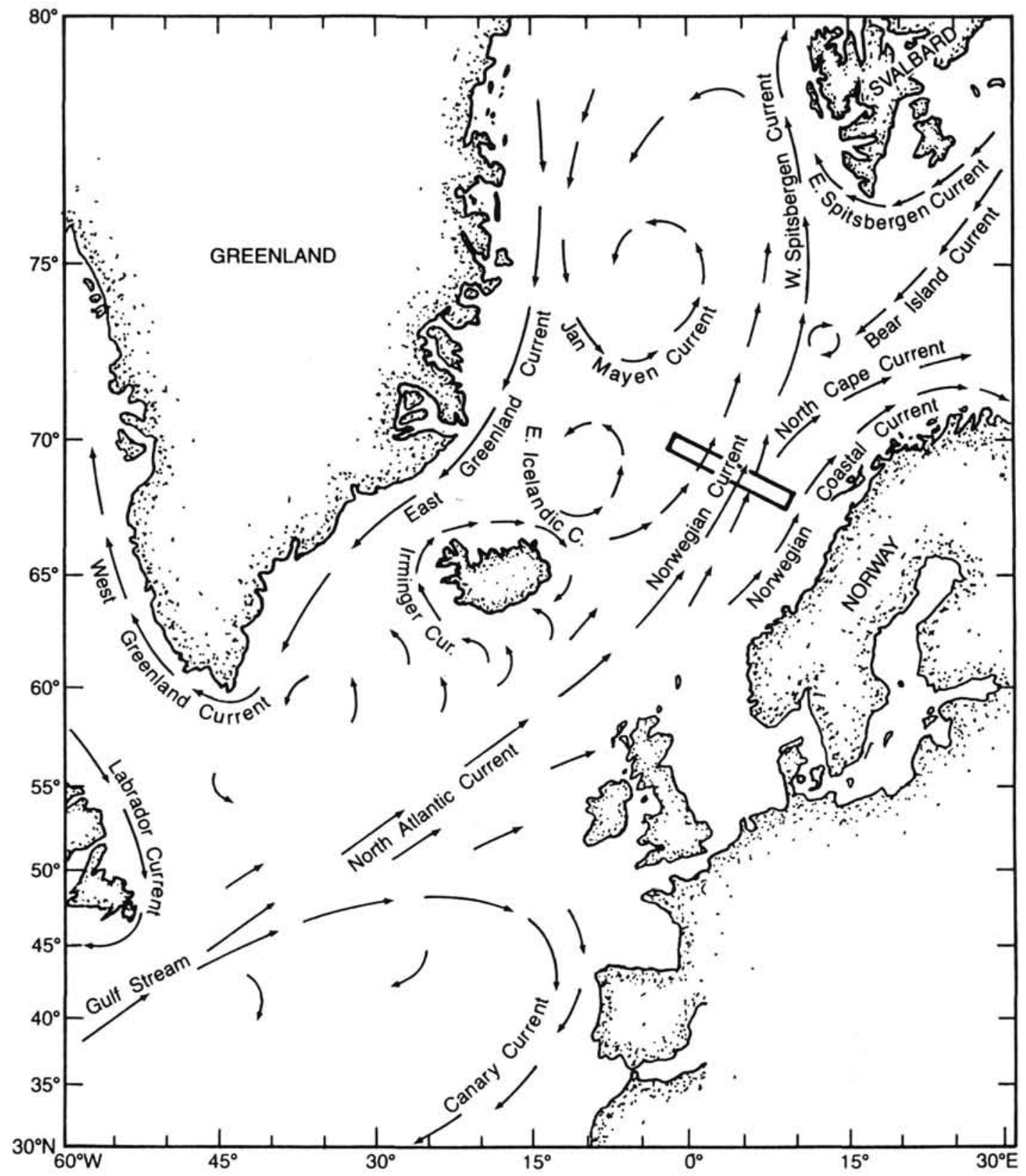

Figure 3. Surface-water currents of the Norwegian-Greenland Sea, adopted from Kellogg (1975, 1976). Bar marks ODP Leg 104 paleoenvironmental transect.

comprise Paleogene, Neogene, and Quaternary stratigraphies monitoring the transition from early Cenozoic warm climates to the recent climatic extremes.

Site locations on the Vøring Plateau, however, were known to have shortcomings based on prior DSDP Leg 38 results (Talwani, Udintsev, et al., 1976). Particular drawbacks:

1. The depositional environment under the Norwegian Current probably comprises the Northern Hemisphere deep-sea area least suited to detect the earliest onset of glacial-type climates.

2. There is a high probability of encountering major hiatuses, particularly in the Miocene and Pliocene (Schrader et al., 1976; Ehrmann and Thiede, 1985).
3. There are known occurrences of carbonate-poor, scarcely fossiliferous, sequences with remains of partially endemic floras and faunas. This results in severe difficulties in correlating Norwegian-Greenland Sea biostratigraphies with temperate ocean records (Schrader et al., 1976).

These problems were to be minimized in part by drilling a transect (Figs. 3, 4) across major surface and bottom-water boundaries, thereby providing a basis for a new synthesis of the history of the depositional environment of the NorwegianGreenland Sea. The depositional environment has changed under the influence of two widely different processes, tectonic and paleoclimatic evolution. The tectonic growth of the NorwegianGreenland Sea is due to seafloor spreading (Talwani and Eldholm, 1977) following a late Mesozoic-early Cenozoic rifting 


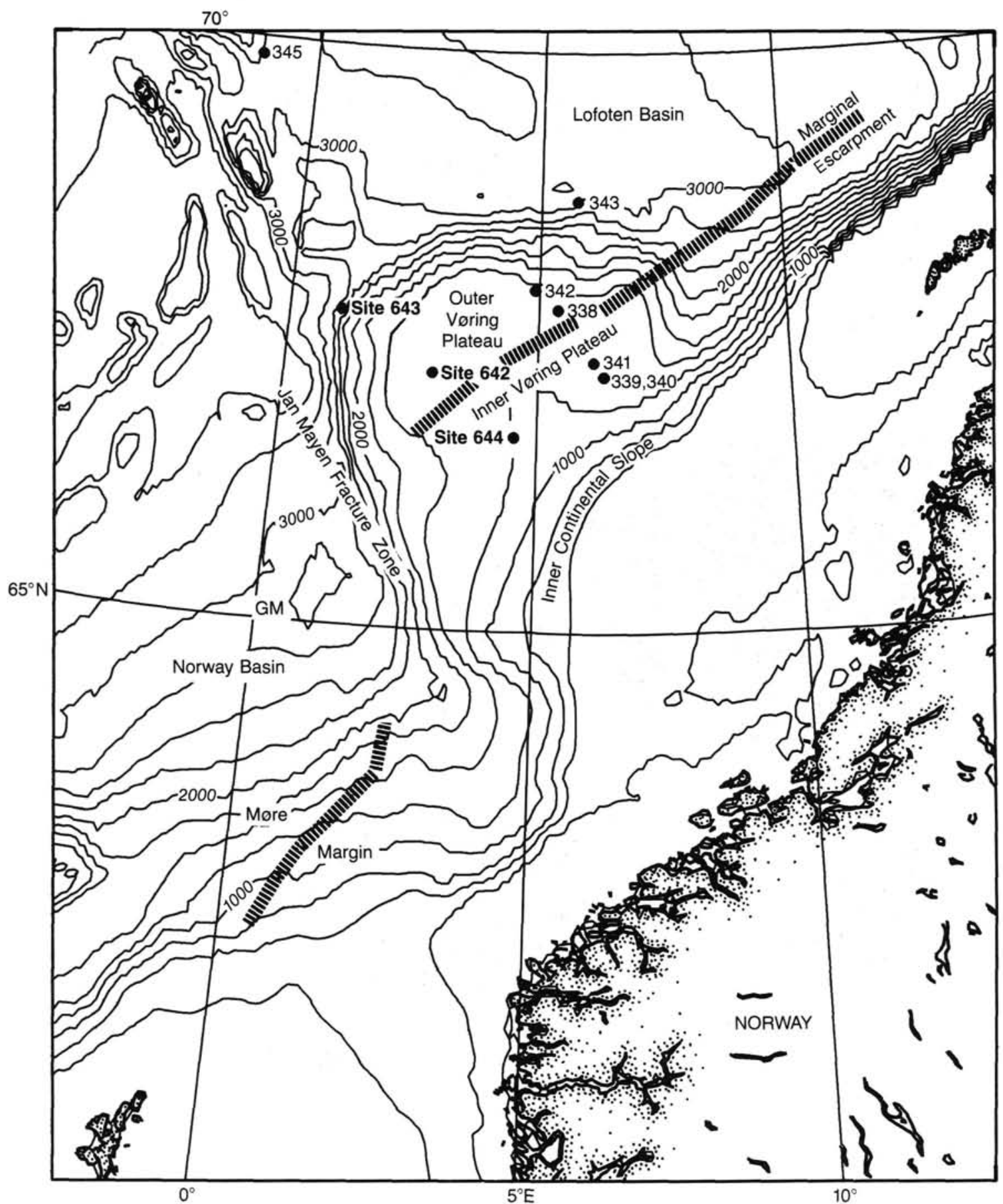

Figure 4. Bathymetry of the Norwegian continental margin, $62^{\circ}$ to $70^{\circ} \mathrm{N}$ including the Vøring Plateau (contour interval $250 \mathrm{~m}$ ) with locations of ODP Leg 104 and DSDP Leg 38 drill sites.

event. Changes in the Northern Hemisphere paleoclimate and Norwegian-Greenland Sea paleoceanography since 55-60 Ma are inextricably linked to the Norwegian-Greenland Sea paleoceanographic history. These two different processes are generally dealt with separately, though this is not always possible or, in some cases, desirable.

In this synthesis, we attempt to develop the history of temporal variability in the depositional environment of the eastern Norwegian-Greenland Sea. The validity of this history depends upon the resolution of the ODP Leg 104 and DSDP Leg 38 stra- tigraphies, their intercorrelation, and correlation with established time scales (Goll, this volume). It is evident from the individual stratigraphic studies and the biostratigraphic synthesis (Goll, this volume) that many aspects of the detailed temporal framework of the Cenozoic depositional environment have not been solved satisfactorily. Therefore this contribution is only an intermediate step in an ongoing discussion.

We have also tried to separately describe sediment parameters controlled by the properties of the surface-, intermediateand bottom-water masses (Figs. 5, 6, 7), from those controlled 

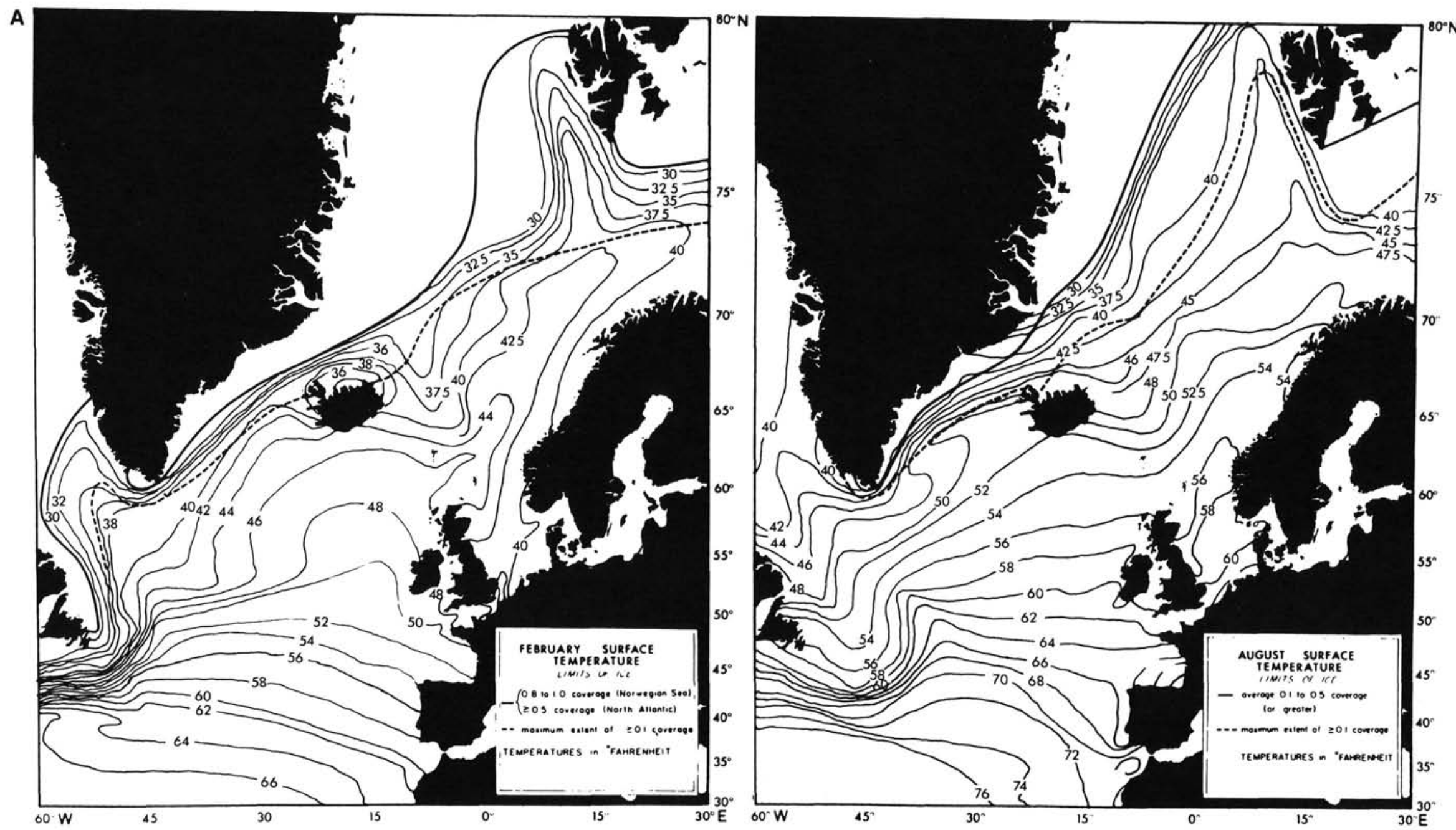


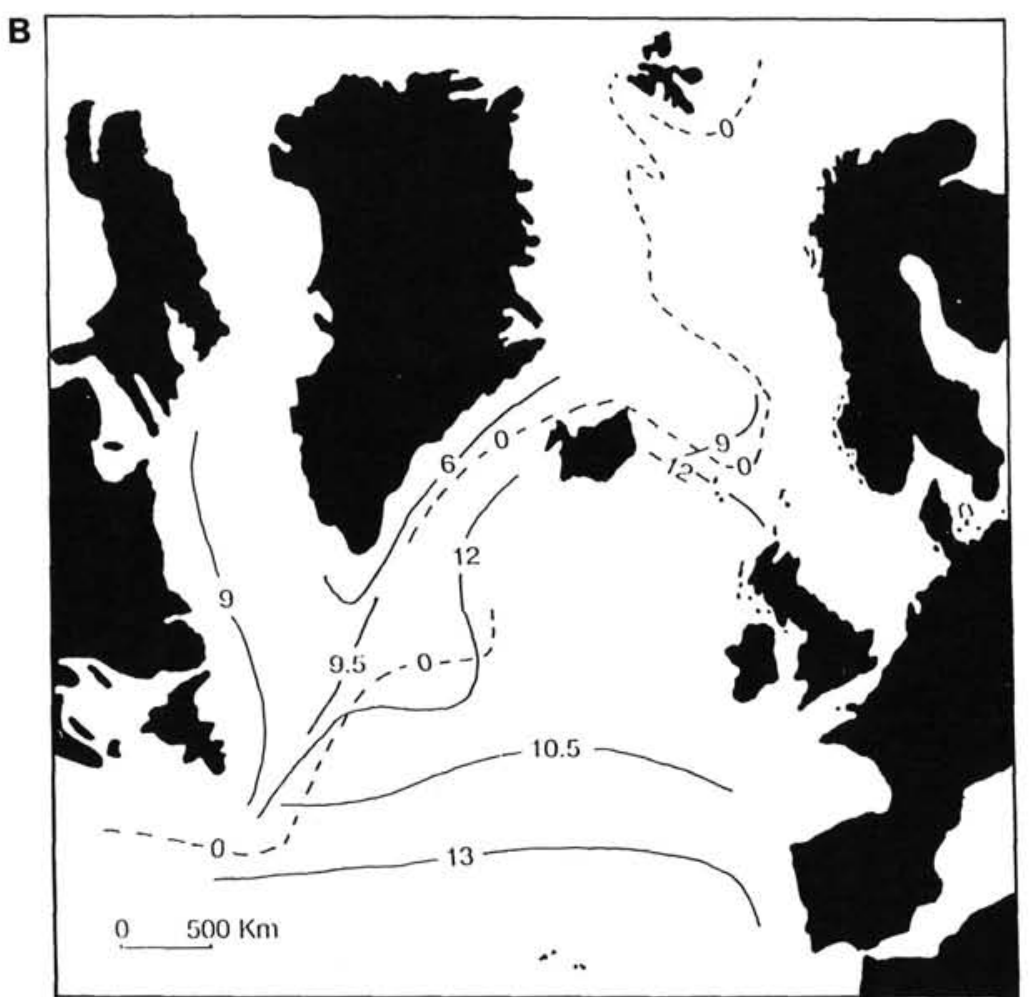

Figure 5. (A) Surface-water temperatures $\left({ }^{\circ} \mathrm{F}\right)$ of the Norwegian-Greenland Sea (from Kellogg, 1976). (B) Spatial variability of the polar front in the area of the Norwegian-Greenland Sea (compiled from various sources, from Thiede, 1988). Numbers indicate ages of position of polar front in Ka. 


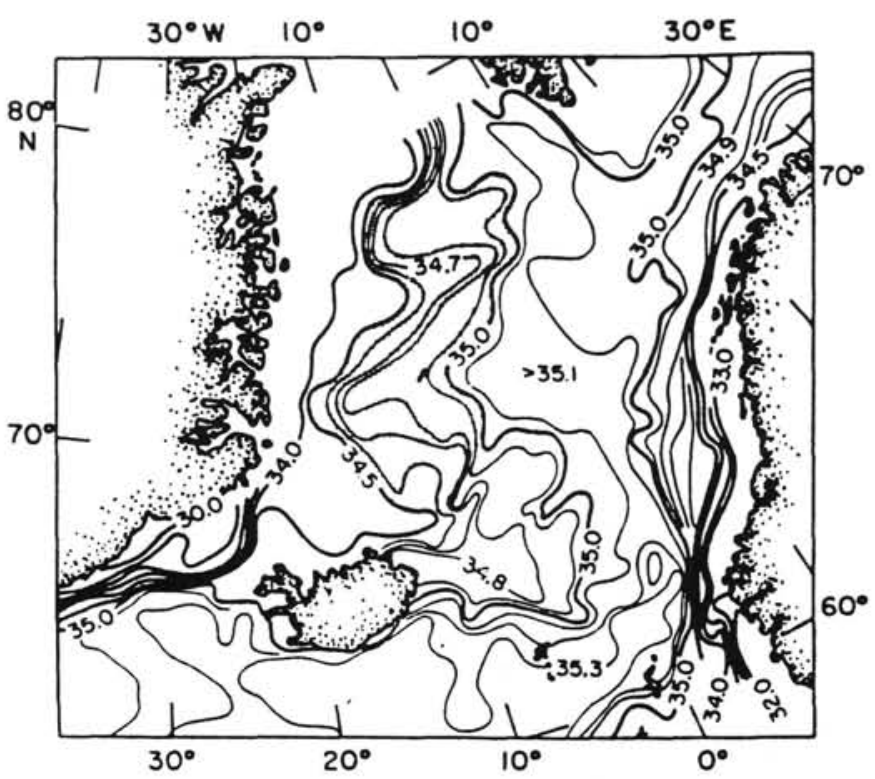

Figure 6. Surface-water salinities $(\%)$ of the Norwegian-Greenland Sea in summer 1958 (Koltermann, 1987).

by the climate on the continents adjacent to the NorwegianGreenland Sea. Sediment properties caused by post-depositional diagenetic processes are discussed elsewhere (Henrich, this volume).

\section{MODERN NORWEGIAN SEA ENVIRONMENTS}

The drill sites on the Vøring Plateau were located along a transect sampling pelagic and hemipelagic sediments deposited under the influence of characteristic elements of the overlying water column below. Previous studies of Quaternary sediments have shown that the distribution patterns of the mainly biogenic sediment components reflect the properties of the overlying water masses (Kellogg, 1976; Streeter et al., 1982; Mackensen et al., 1985); however, it is often not clear how and by which processes the hydrographic properties are preserved in the sediment.

\section{Modern Surface-water Oceanography}

The most important elements of the modern NorwegianGreenland Sea surface-water circulation are the temperate to subpolar Norwegian Current in the east and the ice-covered, cold polar East Greenland Current in the west (Fig. 3). Both current systems generate very steep east-to-west oceanographic gradients across the Norwegian-Greenland Sea. They are separated from the adjacent inner shelf regions by water masses of reduced salinities. Off Norway, this shelf-water mass is called the Norwegian Coastal Current. Its offshore boundary is seasonally highly variable, extending at times west of the shelf edge. The ocean-basin boundaries of these current systems are punctuated by large counterclockwise gyres that result in the advection of Atlantic and polar waters to the central NorwegianGreenland Sea. The location of these gyres may be associated with major seafloor morphologic features. One of these major gyres is located over the Vøring Plateau, and others are found in the Fram Strait, to the north of Jan Mayen Ridge and Iceland. Recently, satellite imagery has demonstrated that these watermass boundaries are highly variable, revealing considerable smallto intermediate-scale turbulence.

Modern sea-surface temperatures over the Vøring Plateau range between 6 and $8^{\circ} \mathrm{C}$ (Koltermann, 1987) (Fig. 5). Furthermore, the modern surface salinities (Fig. 6) also reveal the general basin-wide anticlockwise movement of the surface-water masses, locally modified by large gyres. At the Vøring Plateau, modern sea-surface salinities of the Norwegian Current range between 35.1 and $35.3 \%$, but the steep and horizontally highly turbulent gradient between the Norwegian Current and the Norwegian Coastal Current, with salinities $<33 \%$, may result in rapid, in part seasonally controlled, changes of the surface-water salinities.

\section{Modern Intermediate- and Bottom-water Oceanography}

The relatively simple structure of the Norwegian-Greenland Sea surface water hides a complicated intermediate- and bottom-water configuration (Mosby, 1959; Aagard et al., 1985; Koltermann, 1987); see Figure 7. Because of its importance for deep-water circulation of the world ocean, the reconstruction of the variability in the most recent geologic past is of high scientific interest.

In the eastern Norwegian Sea the Norwegian Coastal Current and the Norwegian Current overlie the cold arctic water as westward-thinning lenses. In the central part of the basin, this generates a largely layered water-mass structure with cold (mostly $<0-1{ }^{\circ} \mathrm{C}$ ) and dense (salinity $>34.9 \%$ ) water below $500 \mathrm{~m}$. This structure is significantly different from the water-mass structure of the Greenland Basin and on the Iceland Plateau. In these latter regions, downwelling transports cold and oxygen-rich but not highly saline water in the central part of the Greenland gyre, at $75^{\circ} \mathrm{N}, 2^{\circ} \mathrm{W}$, to great depths. The renewed deep water is collected in the deepest part of the Greenland Basin (Koltermann, 1987), and distributed radially by a deep seated gyre. In the western boundary region it is mixed with deep waters from the Arctic Ocean. It is presently unknown if this gyre and the deepseated mixing processes experience large seasonal changes.

Aagard et al. (1985) suggested an alternate mode of deep-water renewal in polar regions through brine formation in adjacent shelf areas. The brine, dense and rich in salt as well as oxygen, originates during winter-ice formation. It moves over the shelf edge, down the continental slope into the deep-sea basins and presumably plays an important role in sediment transport. During glacial times most of the Arctic Ocean and the NorwegianGreenland Sea was permanently ice-covered (Fig. 2) and the central Greenland Basin mode of bottom-water renewal probably did not exist. Brine formation along the circum-arctic shelf region during that time might have been much more important than during Holocene time. This may elegantly explain the continued existence of oxygenated bottom waters for most of the Glacial, indicated by sediment data (Henrich et al., in press).

\section{Relationship of Norwegian-Greenland Oceanography to Modern Northern Hemisphere Climate}

The modern Northern Hemisphere climatic zonation shows a close correspondence to the hydrographic properties of the surface-water masses, particularly in the Norwegian-Greenland Sea and adjacent areas. The Norwegian Current represents a large heat flux that warms the eastern Norwegian Sea and the Scandinavian peninsula. The development of the Norwegian Current toward the end of the Pleistocene resulted in a rapid deglaciation of Fennoscandia, whereas a continental ice-sheet has existed in Greenland since at least the last Interglacial (Robin, 1983). The repeated occurrences of similar sediment facies in Leg 104 cores and in gravity and piston cores (Henrich, this volume) yield ample evidence for the frequent repetition of this icesheet formation and destruction process.

The modern Norwegian-Greenland Sea is located under a wide northern loop of the Northern Hemisphere "planetary wave" (Ruddiman and Raymo, 1988). The location of this loop, in turn, might be controlled by orography (Bolin, 1950). It guides many of the high- and low-pressure systems traveling northeastward across the Norwegian-Greenland Sea. A major unresolved issue is understanding the mechanisms that split the 


\section{Distance}

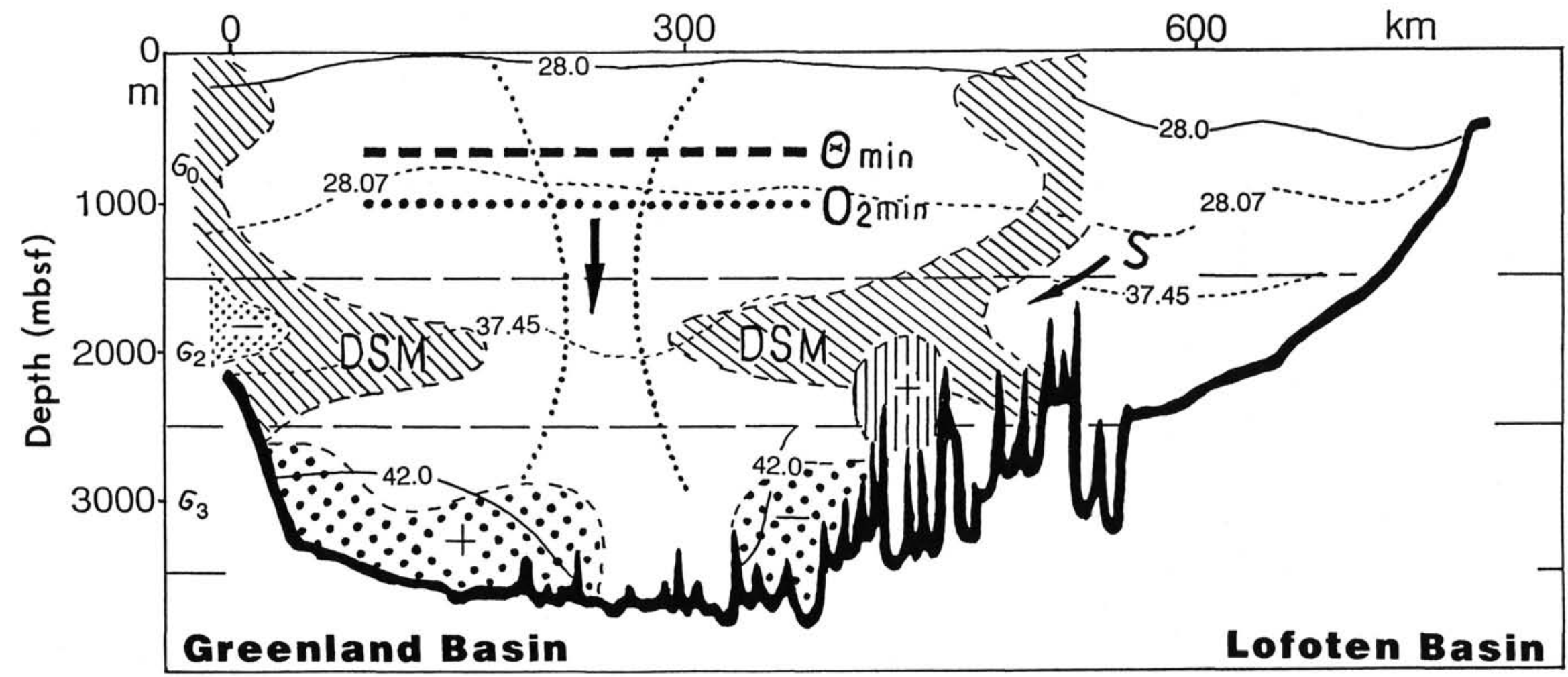

Figure 7. Dominant hydrographic structures along a zonal section across the Greenland and Lofoten basins (Koltermann, 1987). DSM = Deep Salinity Maximum. Arrows suggest large-scale movement of water masses. 
East Greenland Current. Of particular interest is the eastwardturning gyre north of Iceland, which allows sea ice to cover major parts of the Norwegian-Greenland Sea. Such events happened on several occasions in historic times (Lamb, 1972).

\section{MAIN DRILLING RESULTS (ODP LEG 104 AND DSDP LEG 38)}

The positions and lithologic summary columns of the ODP Leg 104 drill sites are shown along an interpreted seismic reflection line across the Vøring Plateau in Figure 8. The paleoenvironmental objectives of Leg 104 were addressed by coring a site transect (Figs. 1 and 4) across the Vøring Plateau with the deep basement Site 642 (in 1277 m of water) as its centerpiece. Seismic reflection profiles (Fig. 8) showed a Neogene and Quaternary sedimentary section overlying basement in this region. Basement rock, cored during DSDP Leg 38 at Sites 338 and 342, was known to consist of Eocene basalts (Talwani, Udintsev, et al., 1976). Site 643 , located northwest of Site 642 , sampled sediments underlying the western flank of the Norwegian Current while Site 644 was located near the Norwegian Current-Norwegian Coastal Current front. The sedimentary section at the three Leg 104 sites can be seismic-stratigraphically correlated, aiding interpretation of lateral variability in the overlying water masses. In addition to any horizontal differences in sediment composition and stratigraphy, the three sites also allowed us to sample several levels of the water column to provide data on the history of the Norwegian Sea water column stratification as well as on variations of the rates of bottom-water renewal.

DSDP Leg 38 employed rotary drilling and discontinuous coring for most of the sites (Talwani, Udintsev, et al., 1976). However, drilling techniques used during Leg 104 (XCB and APC) allowed recovery of continuous and undisturbed cores from most of the penetrated sediment sections. Nevertheless, the DSDP Leg 38 sites on and close to the Vøring Plateau yielded important data that have also been considered in this synthesis.

Although Paleogene rocks and sediments were recovered at Sites 643 and 642 , the limited biostratigraphic resolution and lack of confident age control in that section prevent an adequate interpretation. The main emphasis of this synthesis has therefore been placed on the Neogene and Quaternary portions of the drilled sections that comprised the transition from a preglacial to a glacial Norwegian-Greenland Sea.

The lithostratigraphy of the ODP (Fig. 8) and DSDP sites on the Vøring Plateau is briefly described to provide a background for understanding their depositional paleoenvironment. The bulk of the data have been published by Eldholm, Thiede, Taylor, et al. (1987) and Talwani, Udintsev, et al. (1976). Much of the detailed sediment data described herein are contained in other chapters of this volume.

\section{ODP Site 642}

At Site 642 we penetrated a 900 -m-thick sequence of basaltic rocks that have been subdivided into a lower series and an upper series, and four lithologic sedimentary units of late Eocene to Quaternary in age. The igneous rocks of the lower series below reflector $\mathrm{K}$ (Fig. 8) consist of dacitic flows and interlayered sediments contaminated by rocks of continental affinity. The upper series consists of numerous flows and intercalated sediments forming the dipping reflector sequence in the seismic record. Both series are late Paleocene/early Eocene in age and are described by Viereck et al., Parson et al., and Eldholm et al. (each, this volume). On top of the volcanic sequence rests a 30 to 40 -m-thick layer of lower Eocene sediments. These altered volcaniclastic sediments are obviously derived from the volcanic basement and are separated from the overlying Miocene sediments by a long hiatus.
The Neogene and Quaternary sequence comprises a thick Miocene pile of deposits that are enriched in siliceous biogenic sediment components. Intercalations of biogenic calcareous sediments with the biosiliceous material only occur in the uppermost part of the Neogene section and in the Quaternary. Terrigenous material dominates the middle Pliocene to Quaternary lithologic section. Most of the Neogene and Quaternary cores are fossiliferous, from which a detailed biostratigraphy has been established. Excellent recovery and quality of the sediment cores in the Neogene and Quaternary section yielded a high-quality stratigraphic and paleoenvironmental record.

\section{ODP Site 643}

Site 643 penetrated more than $550 \mathrm{~m}$ of thick Paleogene and Neogene/Quaternary sediments overlying basaltic rubble that may represent a volcanic basement. Eocene to Miocene sediments are mostly clayey and rarely fossiliferous. It is only in the middle to upper Miocene section that the sediments contain a considerable amount of biosiliceous material. Intercalations of biogenic calcareous sediment components result in a variable lithology in the uppermost Miocene and Pliocene section that in the middle Pliocene grades into sediments dominated by the terrigenous input of the glacial/interglacial facies (Henrich et al., this volume). The core recovery was generally excellent, but was intermediate to poor in the lowermost Miocene section.

\section{ODP Site 644}

Site 644 penetrated a 256-m-thick Pliocene and Pleistocene sequence of dominantly terrigenous sediments with relatively thin biogenic intercalations. The sediments have been subdivided into two lithologic units. The lower unit represents a mostly preglacial depositional environment without the input of coarse terrigenous ice-rafted debris. The upper unit is characterized by repeated intercalations of horizons containing a large proportion of ice-rafted terrigenous debris.

\section{DSDP Site 338}

DSDP Site 338 (Fig. 4) was drilled in $1297 \mathrm{~m}$ of water just west of the Vøring Plateau escarpment (VPE). It penetrated 437 $\mathrm{m}$ of sediments. The oldest sediments consist of lower Eocene sandy muds and mudstones. Basalt with a diabasic texture underlies the sediments. Most of the Eocene to Miocene sediments are diatomaceous oozes, whereas the lower Eocene sediments include a large proportion of sandy muds that were deposited over the basaltic basement. The Pliocene-Pleistocene sediments consist of olive-gray muds, sandy muds, and calcareous oozes with pebbles.

\section{DSDP Sites 339 and 340}

Both sites were drilled in a diapir province in the Vøring Basin southwest of Site 338 . Site 339 was drilled in $1262 \mathrm{~m}$ of water, penetrating $108 \mathrm{~m}$ of Eocene to Quaternary diatomaceous ooze overlain by glacial sediments. The Eocene part of the section was believed to constitute diapiric material.

DSDP Site 340 was drilled in $1217 \mathrm{~m}$ of water. It comprised two lithologic units, a yellow-green diatom ooze with ash horizons of late to middle Miocene age and a thin glacial Pleistocene sandy muddy unit on top of it. The site was located on a topographically steeper part of the diapir, which explains the reduction in thickness of the youngest glacial sediments.

\section{DSDP Site 341}

Site 341 is located near DSDP Sites 339 and 340 over the thick part of the stratified sediment section in the Vøring Basin. It was positioned in $1439 \mathrm{~m}$ of water, and dominantly Miocene to Pleistocene biogenic siliceous and glacial sediments were recovered, with a core recovery of close to $70 \%$. The section there 


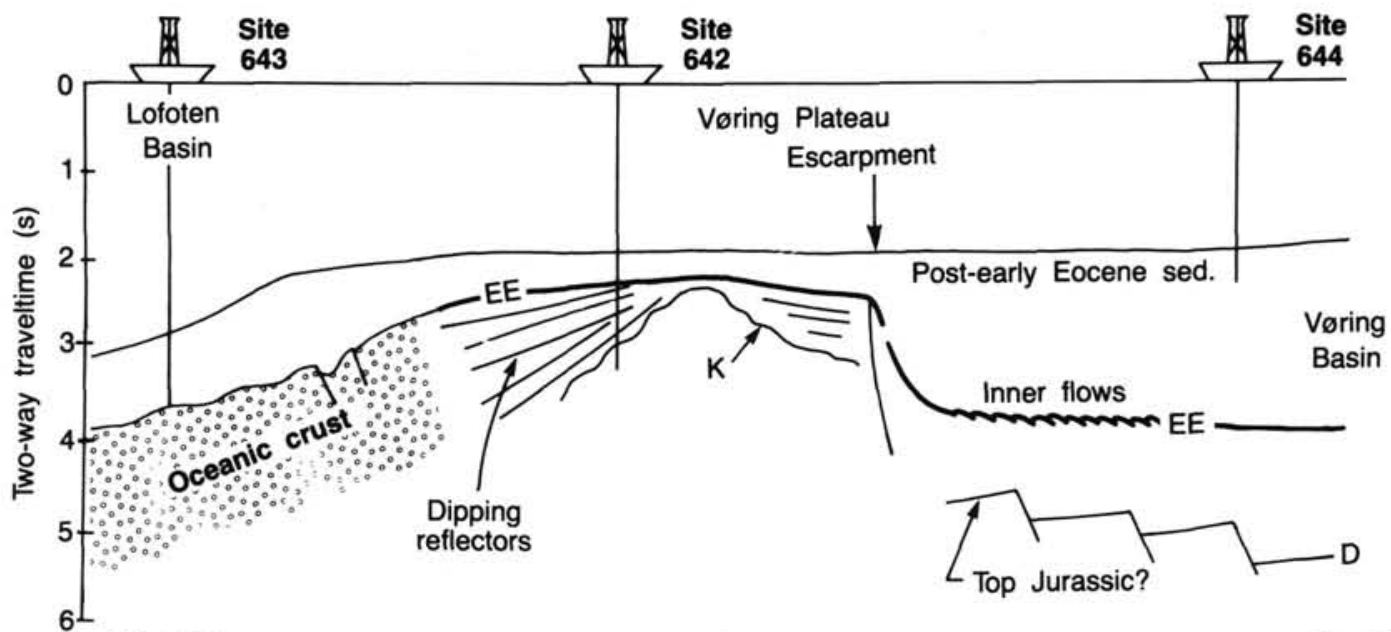

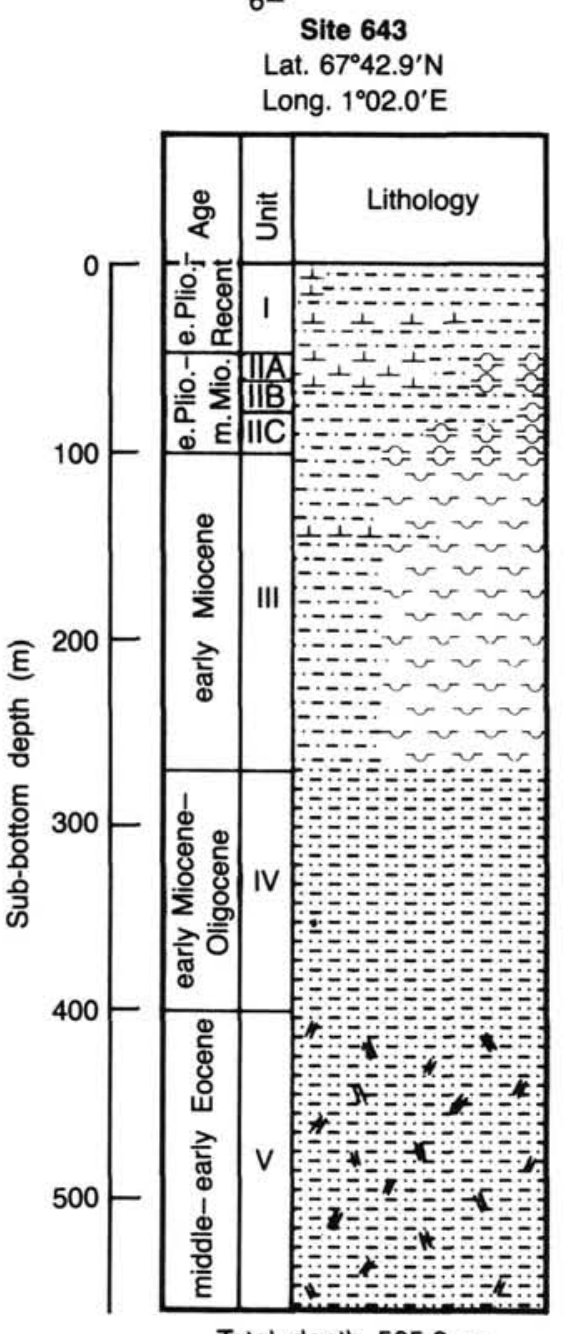

Total depth $565.2 \mathrm{~m}$

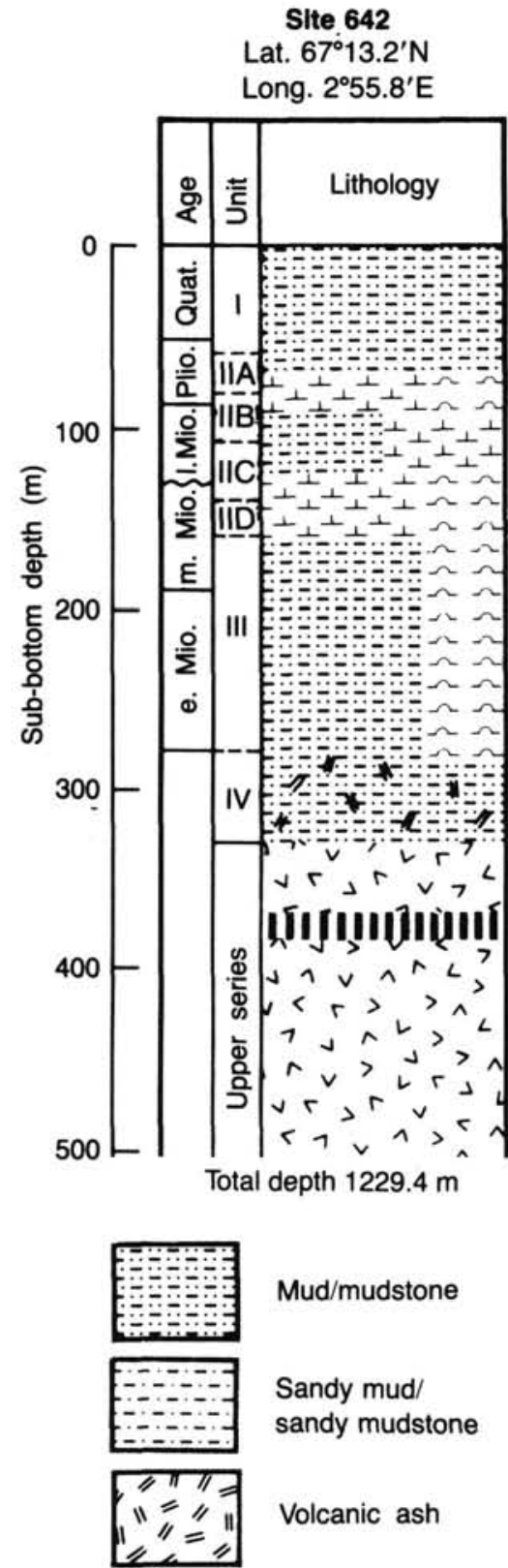

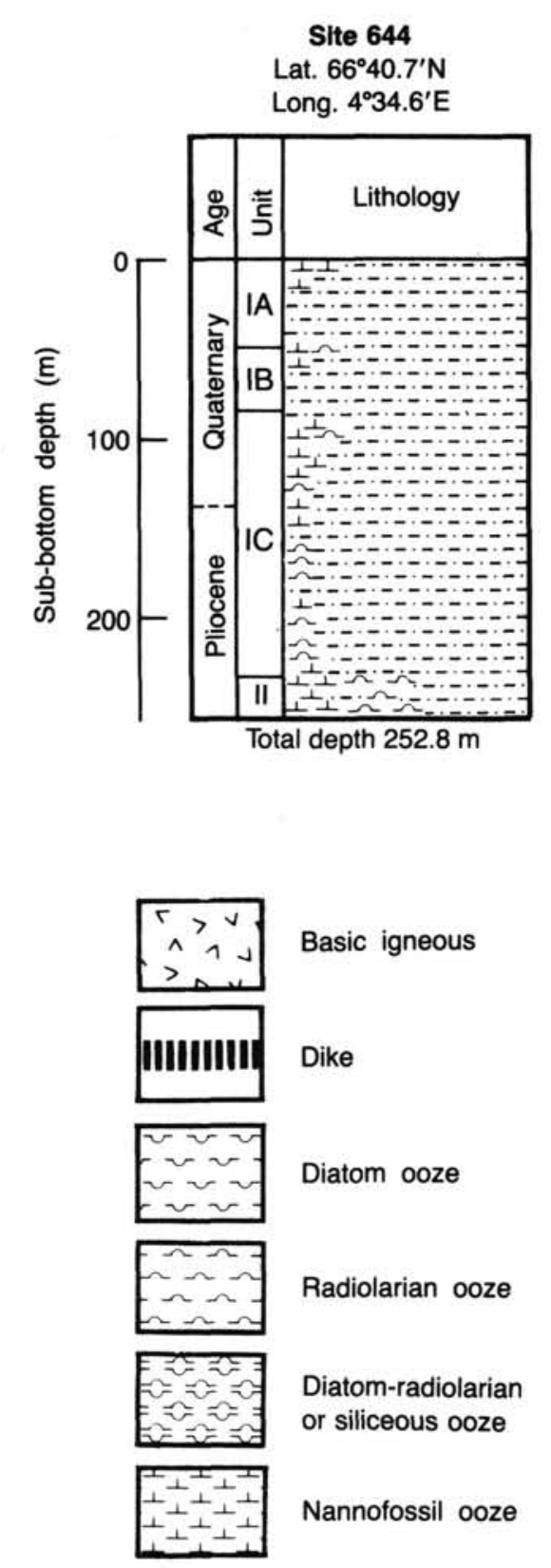

Site 644

Lat. $66^{\circ} 40.7^{\prime} \mathrm{N}$

Long. $4^{\circ} 34.6^{\prime} \mathrm{E}$

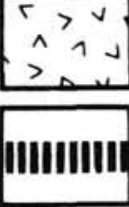

Basic igneous

Dike

Diatom ooze

Radiolarian ooze

Diatom-radiolarian or siliceous ooze

Nannofossil ooze

Figure 8. Simplified geologic section across the Vøring Plateau with positions and lithologic columns of ODP Sites 642, 643, and 644 (Eldholm, Thiede, Taylor, et al., 1987). 
consists of a very thick sequence $(323 \mathrm{~m})$ of glacial-type sediments that directly overlies middle Miocene deposits. Allochthonous Tertiary material was an additional sediment component contributing to the thickness of the glacial sequence. In addition, Pleistocene sediments were observed that contained shallow-water benthic faunal elements.

\section{DSDP Site 342}

DSDP Site 342 is located in $1303 \mathrm{~m}$ of water a short distance northwest of DSDP Site 338 and northeast of ODP Site 642 . The site penetrated only $170 \mathrm{~m}$ of Pleistocene to Miocene deposits. The older deposits comprised diatomaceous oozes and the Pleistocene deposits consist of calcareous pebbly mud and sandy mud. Core recovery was very poor at this site and hence no reliable stratigraphic record was obtained. The site reached basement at 153.2 mbsf, where Eocene basalts were encountered.

\section{DSDP Site 343}

This site is located on oceanic basement at the foot of the plateau north of Site 342, a location comparable to ODP Site 643. Poor core recovery there sampled a highly disturbed sediment section, revealing only a gross stratigraphic subdivision of sediment overlying basalt. This basement is overlain by lower and middle Eocene sediments and Pliocene-Pleistocene terrigenous to sandy muds with nannofossil horizons and pebbles.

\section{PALEOENVIRONMENTAL STUDIES}

This paleoenvironmental synthesis requires interpreting information contained within recovered fossil groups, in addition to sedimentologic data, within a reasonable temporal framework. Stratigraphic data produced by numerous specialists in this volume were collectively used by Goll (this volume) to establish the chronology used herein. Microfossils and sedimentological data are then correlated with surface- and bottom-water properties and paleoclimatic variability.

\section{Chronology}

The chronology presented in Goll (this volume) represents one stage of an ongoing process of zonation definition and correlation with other age controls. This time scale has evolved since the completion of Leg 104. It is based upon the pelagic biochronology of Berggren et al. (1985), which has been applied to data from this entire volume, and

1. The numerous biostratigraphic studies in this volume, as well as the data in Eldholm, Thiede, Taylor, et al. (1987). Diatoms comprise the only major, stratigraphically important microfossil group whose data have not been revised;

2. The very detailed magnetostratigraphic studies of Bleil (this volume) and Schoenharting and Abrahamsen (this volume);

3. A few radiometric dates, produced by Smalley et al. (this volume); and

4. A detailed correlation with DSDP Leg 38 stratigraphies, synthesized by Schrader et al. (1976) and revised by Goll (this volume).

Major stratigraphic uncertainties persist about existence, correlation, and precise timing of some hiatuses, as well as limited age control in major parts of the Paleogene and lower Neogene sedimentary sequences, and of the volcanic rocks. Therefore, age vs. depth plots for Sites 642,643 , and 644 (Fig. 9) are shown for only the last $25 \mathrm{~m}$.y. as older intervals have poor age control (see Goll, this volume, for further details).

The frequency of the hiatuses (Fig. 9) clearly documents that ODP Leg 104 drilling did not escape the numerous interrupted stratigraphic records that are typical for the Norwegian-Greenland Sea (Ehrmann and Thiede, 1985) and for the entire North Atlantic (Thiede and Ehrmann, 1986). DSDP data showed that the Norwegian-Greenland Sea was affected by erosive processes that peaked during the latest Miocene, although intensive erosion also occurred during the late Oligocene and throughout the Miocene. The erosive intensity of bottom-water circulation decreased dramatically during the Pliocene, to its late Quaternary minimum. The numerous hiatuses in Leg 104 recovery attest to this widespread pattern. These observations are confirmed even after revision of the DSDP Leg 38 stratigraphies and seem to be an important clue to the vigor of the Norwegian-Greenland Sea bottom-water circulation.

Comparison of the revised Leg 38 chronologies with those of Leg 104 shows that the latter succeeded in penetrating distinct parts of the Cenozoic Norwegian-Greenland Sea sedimentary sequence. The stratigraphic coverage provided by combined Leg 104-Leg 38 cores marks a significant step toward resolving the Norwegian-Greenland Sea paleoenvironmental history. However, only about $50 \%$ of the time span that needs to be considered in a comprehensive Norwegian-Greenland Sea synthesis can actually be discussed based on the current sedimentary evidence (Goll, this volume).

In the following, a few general remarks are made in reference to the chronology developed for the history of the sedimentary record of the ODP Leg 104 sites. The biostratigraphies are spread throughout 13 papers that treat a broad range of topics and aspects of the biostratigraphic problems of marine and terrestrial fossil groups. Of the terrestrial microfossil groups only pollen and spores have been studied, but they provide, together with the dinoflagellates, a stratigraphic framework throughout the entire Tertiary. They have also been found in parts of sequences that are otherwise very difficult to date biostratigraphically.

The marine microfossil groups studied for this volume comprise dinoflagellate floras, calcareous microfossils such as $\mathrm{Bol}$ boforma, calcareous nannofossils, foraminifers, and siliceous microfossils such as ebridians, actiniscidians, radiolarians, and silicoflagellates. Thus the marine microfossil groups comprise both planktonic and benthic organisms although the former are dominant. Comparison of biostratigraphic zonations is hampered by differences both in sampling frequency down core and thoroughness of the individual studies. Goll (this volume) discusses the biostratigraphies developed for each of the individual groups, noting advantages and disadvantages in his summary.

Norwegian-Greenland Sea biostratigraphy temporal resolution becomes more questionable considering datums must be correlated to temperate localities in the North Atlantic or even more distant regions. Even the biostratigraphy developed by Schrader et al. (1976) proved to be a local stratigraphy valid only for the Norwegian-Greenland Sea. Furthermore the endemic properties, lower diversity, and slowly evolving taxa of Norwegian-Greenland Sea floras and faunas prevent finding easy solutions to these stratigraphic problems. A number of the marine assemblages have clearly arctic affinities. These compound the problem as Cenozoic biostratigraphic sequences of the Arctic Ocean proper are virtually unstudied (Thiede et al., in press).

The sedimentary sequences of some sites, in particular Site 643 , contain evidence of slumping in the Neogene and Quaternary. The number of slumping events detected through detailed stratigraphic analysis remains unclear. But a number of correlation uncertainties between Site 643 to 642 and of the individual holes at Site 642 may be related to such mass movements.

Specific problems arose when we tried to date the lowermost parts of Holes $643 \mathrm{~A}$ and $642 \mathrm{E}$, particularly within sediment sequences immediately overlying volcanic basement. At Site 642, $38 \mathrm{~m}$ of a glauconite-rich volcaniclastic rock and altered volca- 
A

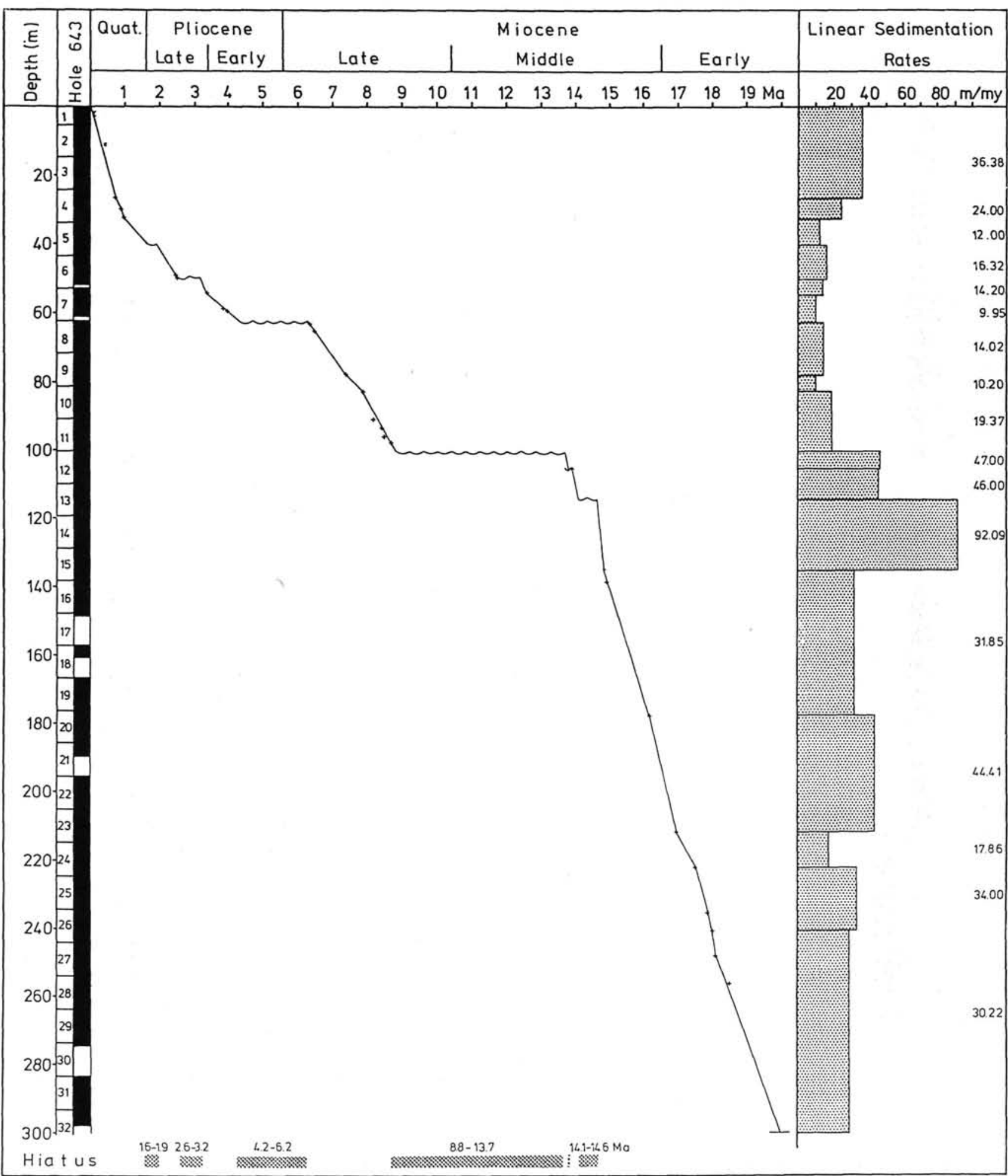

Figure 9. Age vs. depth curves of Miocene to Quaternary sections from ODP Sites 642, 643, and 644 (a-c). From Bohrmann [1988, compiled from data in Goll (this volume), Bleil (this volume), Spiegler and Jansen (this volume), Locker and Martini (this volume), and Qvale and Spiegler (this volume)].

niclastic muds and sands overlie a pebble bed atop a 914-mthick volcanic sequence. According to the absolute dates (Smalley, Qvale, and Qvale, this volume), this part of the sequence is of Eocene age. However, Manum et al. (this volume) found lower Miocene dinocyst assemblages and reworked siliceous microfossils in this same section. The stratigraphic interpretation of the dating differences is presently unresolved.
The basaltic sequence of Site 642 has only been dated biostratigraphically by means of palynomorphs in the volcaniclastic intercalations of the lower series (Manum and Boulter, this volume). They have been dated to early Eocene and questionable Paleocene. No new biostratigraphic data are available for the upper series of basaltic rocks with the numerous intercalated sediment horizons. 


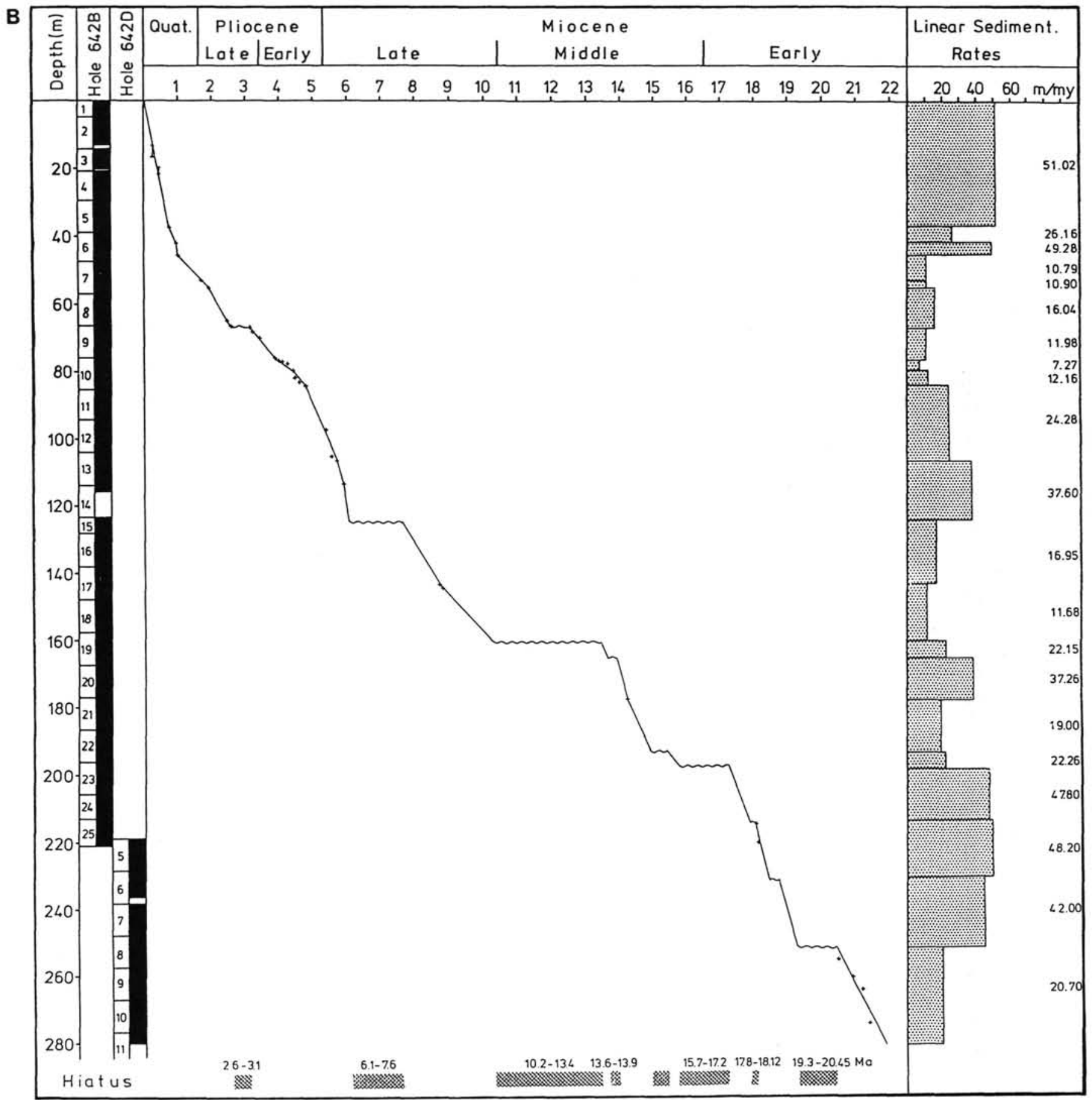

Figure 9 (continued).

At Hole 643A a sharp lithologic contact separates the upper siliceous mud sequence from an underlying 164.5-m-thick section of compaction-laminated mudstones and claystones. Ages across this sharp lithologic contact are disputed. Only approximate age assignments have been made based on sporadic occur- rences of radiolarians (Goll and Björklund, this volume), of calcareous microfossils (Donally, this volume), and planktonic foraminifers (Jansen and Spiegler, this volume). The lower unit rests on a basaltic pebble horizon interpreted as basement. Ages for this sequence are derived from dinoflagellates and sparse, 


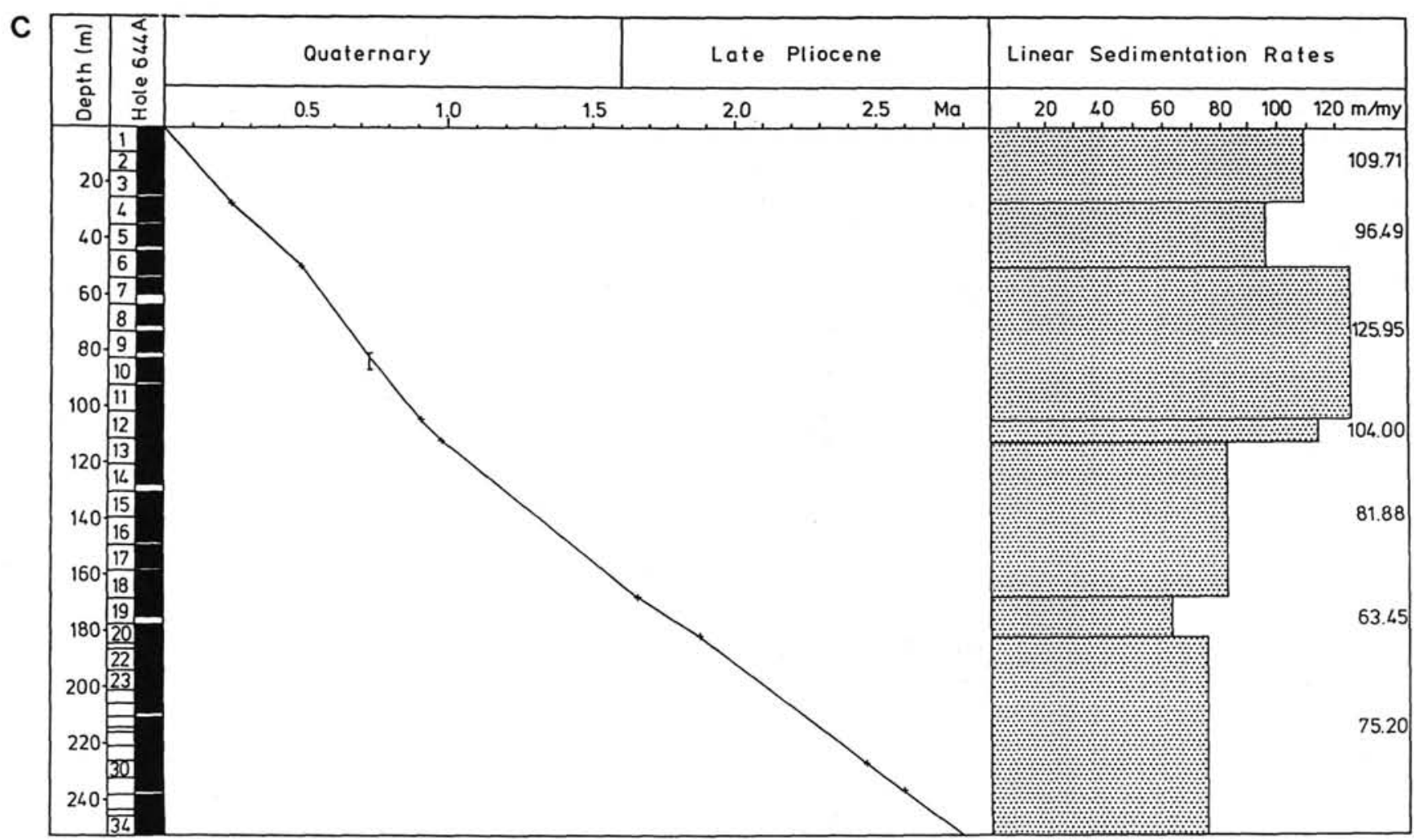

Figure 9 (continued).

arenaceous foraminifer assemblages (Kaminski, 1988). In summary, the ages of sediments immediately overlying volcanic basement at Sites 642 and 643 are presently controversial.

The Pliocene-Quaternary sections are more easily correlated between the various sites, following similar experience in studies of numerous Quaternary cores (Ramm, in press). Site 644 provides an almost complete section, without major hiatuses, to $3 \mathrm{Ma}$. The Miocene siliceous muds first occur at 21.7 Ma, Site 642 , and at $19.0 \mathrm{Ma}$, Site 643 . The oldest sediments with reasonably consistent calcareous fossil records were deposited at nearly $13.6 \mathrm{Ma}$ at Sites 642 and 643 . Combined paleomagnetic and biostratigraphic analyses provide confident age assignments for sediments younger than $8.8 \mathrm{Ma}$ (Chron C4A) at Site 643 and younger than $4.9 \mathrm{Ma}$ (Chron $\mathrm{C} 3 \mathrm{~A})$ at Site 642 . The biostratigraphic correlations are also supported by detailed correlations based on sedimentological data such as coarse, ice-rafted material, and other major sediment components (Figs. 10-20).

\section{Paleoenvironmental Indicators}

Sediments from on and adjacent to the Vøring Plateau provide the basis for studying the depositional paleoenvironment of the Norwegian-Greenland Sea. Changes in these depositional environments are, in turn, controlled by properties and circulation of the surface and bottom waters as well as of the Cenozoic paleoclimate over this area and northwestern Europe. The stratigraphic record of these changes, however, is incomplete due to the numerous hiatuses encountered (Fig. 9). Several sedimentary paleoenvironmental indicators are plotted against depth in core (Figs. 10-14). Because of the age uncertainties in the lower parts of Sites 643 and 642 , we plot only the data from the uppermost $250 \mathrm{~m}$.

In considering the effects of surface-water characteristics, bottom-water characteristics, and the paleoclimate on depositional environment, only the first one can be properly docu- mented by these data. Sedimentary evidence for the latter two is poor and in many ways not unique. Bottom-water characteristics and movements inferred from Leg 104 studies of ostracodes, benthic foraminifers, and sponge spicules are ambiguous. In addition to microfossil evidence however, information on bottom water history can be obtained from the dissolution of calcareous material, sedimentary structures, evidence for reworking and slumping, and the results of erosive processes that generated hiatuses correlatable with hiatus records in the Atlantic and in parts of the Pacific (Goll, this volume). Information for the paleoclimate over the Norwegian-Greenland Sea and adjacent continents since 55-56 Ma can be gained from analyses of clay minerals and oxygen isotope ratios in fossils. The latest Cenozoic paleoclimate history is contained in records of glacial activity over the adjacent land areas, reflected in deep-sea sediments as ice-rafted material.

Surface-water properties can be identified easily by means of a number of microfossil groups that include organic-walled microfossils (dinoflagellates), siliceous microfossils (silicoflagellates, ebridians, actiniscidians, and radiolarians) and calcareous microfossils (calcareous nannofossils and planktonic foraminifers). These groups represent various levels of the marine food webs and react to changes of the surface-water properties in very different ways (Figs. 11-12). An obstacle in deriving a complete history of the surface-water properties since $55 \mathrm{Ma}$ is that many of these fossil groups have no continuous record over the entire time span. Problems with the variability in microfossil assemblages are compounded by the interrupted stratigraphic section. Important hiatuses account for nearly a $50 \%$ loss of a continuous sediment record.

Calcareous microfossils predominate only in the upper Miocene and Pliocene interval and are very scarce in the Pliocene/ Pleistocene section (Fig. 12). The siliceous biogenic oozes typical of the Miocene section become more scarce in the upper Mi- 
ocene, and disappear almost completely in the Pliocene and lower Pleistocene sections (Fig. 11). Lateral differences between the three sites are apparent in the distribution of planktonic foraminifers (Fig. 12) and the proportion of the biogenic opal in the sediments (Fig. 11).

The distribution of ice-rafted material in these sediments is highly variable and is confined to sediments of the past $5.5 \mathrm{~m}$.y. (Fig. 13). This ice-rafted detrital record gives important clues about the dynamics of ice shields adjacent to the NorwegianGreenland Sea, about the input of ice and properties of ice covers in this region, and about local source areas for this detritus.

\section{Paleogeography and Paleobathymetry}

The history of geographic and bathymetric changes in the Norwegian-Greenland Sea (Skogseid and Eldholm, Eldholm et al., this volume) provides important boundary conditions within which the evolution of the Cenozoic Vøring Plateau paleoenvironment can be discussed. A primary result is that the Vøring Plateau experienced an initial uplift during the onset of rifting. This is consistent with the two lava series sampled at Site 642 that were emplaced subaerially and/or in very shallow water. Eldholm et al. (this volume) propose that the breakup at 57.5 Ma was accompanied by a transient phase of much-increased magmatic production. When the transient phase abated 2 to 3 m.y. after breakup, the margin subsided by thermal contraction, possibly with some structural adjustments in the Paleogene. Reconstructions of DSDP Leg 38 drill-site paleobathymetries through backtracking (Thiede, 1979, and others) had suggested that part of the Vøring Plateau was above sea level during the Paleogene. Skogseid and Eldholm (this volume) also show that the Vøring Plateau has undergone differential regional subsidence: the outer part of the plateau subsided faster than the inner portion. Eldholm et al. (this volume) constructed subsidence curves for the three ODP Leg 104 sites based on the volcanic history of each site. They suggest that the margin subsided primarily due to thermal cooling and contraction. Assuming a normal subsidence rate for oceanic crust, and taking into account sediment loading, Site 642 began to subside from approximately $800 \mathrm{~m}$ above sea level at about 55 to $60 \mathrm{Ma}$. Five to ten m.y. later this location sank below sea level; at $30 \mathrm{Ma}$ it was located somewhere between 500 and $1000 \mathrm{~m}$ water depth. At 10 $\mathrm{Ma}$ it was located close to $1 \mathrm{~km}$ below sea level. Subsidence at the Site 643 location also began at 55 to $60 \mathrm{Ma}$. However, basement there is probably normal oceanic crust and was already at about $1 \mathrm{~km}$ of water depth. The crust there subsided regularly to its present water depth of nearly $3 \mathrm{~km}$.

Sedimentological and paleontological data support these reconstructions. Analysis of benthic foraminifers in the lowermost sediments from Site 643 reveal outer neritic to upper bathyal faunas (Kaminski, 1988) whereas overlying sediments contain a diversified deep-water assemblage. At a comparable time, sediments at Site 642 (lithologic Unit IV) were being deposited in a near-shore environment. Rates of subsidence have not been established for Site 644 because of its short stratigraphic record.

\section{HISTORY OF THE NORWEGIAN SEA SURFACE WATERS}

The history of the Norwegian Sea surface waters is more readily accessible than bottom-water histories and part of the paleoclimatic record because extensive sections of the ODP Leg 104 and DSDP Leg 38 cores contain pelagic microfossils whose ecologic requirements are reasonably well known. This information also bears indirectly on the paleoclimatic interpretation. In addition, oxygen isotope data are available for the Neogene and Quaternary. Information on the paleoceanography of the Paleogene surface water is scarce and difficult to interpret, mainly be- cause of the poor preservation of fossil assemblages and of diagenetic alterations of the sedimentary record. In addition, the interpretation of the Paleogene record is complicated because of the severe stratigraphic problems caused by the apparently endemic pelagic faunas and floras (Goll, this volume). The accumulation rates of key sediment components for paleooceanographic interpretation are plotted in Figures 15-20 using mainly Site 643 as an illustration. We have also plotted accumulation rates of selected variables of all three sites (Fig. 20) to compare sediment fluxes of selected sediment components along the Vøring Plateau paleoenvironmental transect.

\section{Paleogene}

Evidence for Paleogene surface-water properties is scarce because the fossil contents of the intra- and immediate supravolcanic sediments (Site 642) are either poorly preserved or are ecologically poorly known. These problems limit the inferences that we can make regarding the original habitat of the fossil assemblages. The Paleogene part of the Site 643 sedimentary section consists dominantly of diagenetically altered mudstones with few pelagic microfossils. Their partly endemic nature has limited biostratigraphic potential.

In addition to the much more frequent pollen and spores, marine pelagic microfossils (dinocysts, diatoms, radiolarians, ebridians, silicoflagellates) have been observed in small numbers in the intravolcanic sediment layers of the lower as well as of the upper volcanic series penetrated at Site 642 (see observations of Mudie, Ciesielski, et al. in Eldholm, Thiede, Taylor, et al., 1987). In places these marine fossils are well preserved. Similar fossil assemblages have also been found in analogous and roughly isochronous sediments of the Thulean volcanic province (Brown and Downie, 1984); they are indicative of a neritic marine to fluvio-deltaic, very near-shore depositional environment. These flora and fauna witnessed the early transgression of the sea into the narrow and young troughs of the Norwegian-Greenland Sea. The role of a possible barrier in the area of an early GreenlandScotland Ridge (Bott et al., 1983), whose submarine segments should have subsided below sea level much later (Thiede and Eldholm, 1983), remains uncertain. The marine transgression may have come from the Arctic Ocean which, based on very few samples, seems to have been fully marine at that time; this incursion would also comfortably explain the endemic nature of some of the pelagic microfossil assemblages (Thiede, 1989, in press). Alternatively, the Greenland-Scotland Ridge was interrupted or bypassed during its early history by shallow straits connecting it to the North Atlantic. The palynomorph assemblages of the suite of samples from the sediments within and immediately on top of the Site 642 volcanic series are dominated by terrestrial palynomorphs, whereas marine forms dominate in the younger Paleogene sequences of Site 643, documenting the pelagic nature of their depositional environments (Boulter and Manum, this volume; Manum et al., this volume). Paleogene linkage to the North Atlantic is also supported by the similarity of the hiatus record to global erosional events as pointed out by Goll (this volume).

\section{Neogene and Quaternary}

The paleoenvironmental theme dominating ODP Leg 104 drill sites is no doubt the transition from the temperate early Neogene to the glacial Pliocene and Quaternary paleoclimate. Changes in the composition of numerous pelagic microfossil groups and sedimentological properties document the step-wise establishment of the glacial depositional environments in great detail as discussed in many previous chapters (Ciesielski and Case; Ciesielski et al.; Donnally; Goll and Bjørklund; Henrich; Henrich et al.; Jansen et al.; Krissek; Locker and Martini; Mudie; Spiegler; Spiegler and Jansen; all in this volume). Therefore, only some of the general trends are pointed out here. 

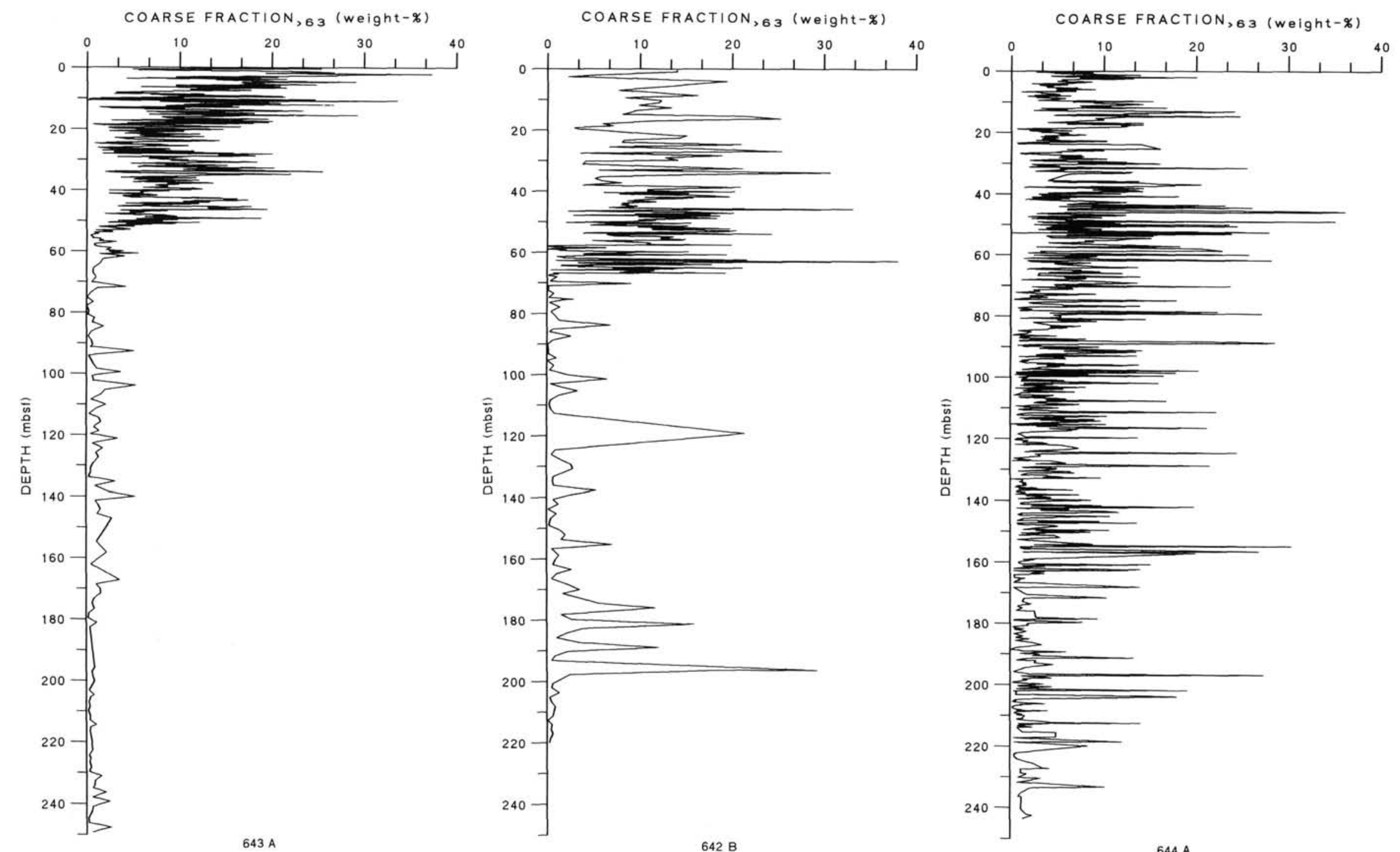

Figure 10. Concentrations of coarse fractions ( $>63 \mu \mathrm{m}$ ) in Holes 643A, 642B, and 644A. Only the upper part of each section is shown. For lower parts see Henrich et al., this volume. 
BIOGENIC OPAL, 63 (ref. to bulk weight-\%)

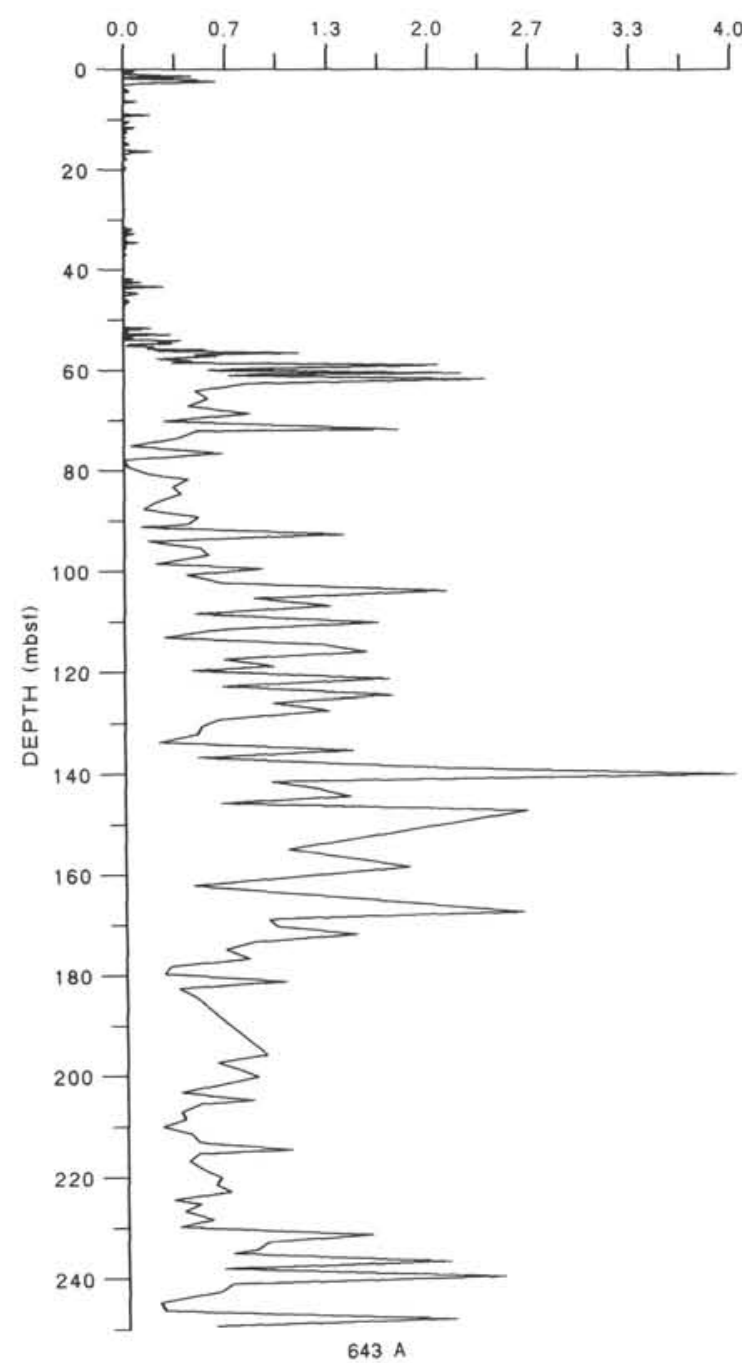

BIOGENIC OPAL, 63 (ref. to bulk weight-

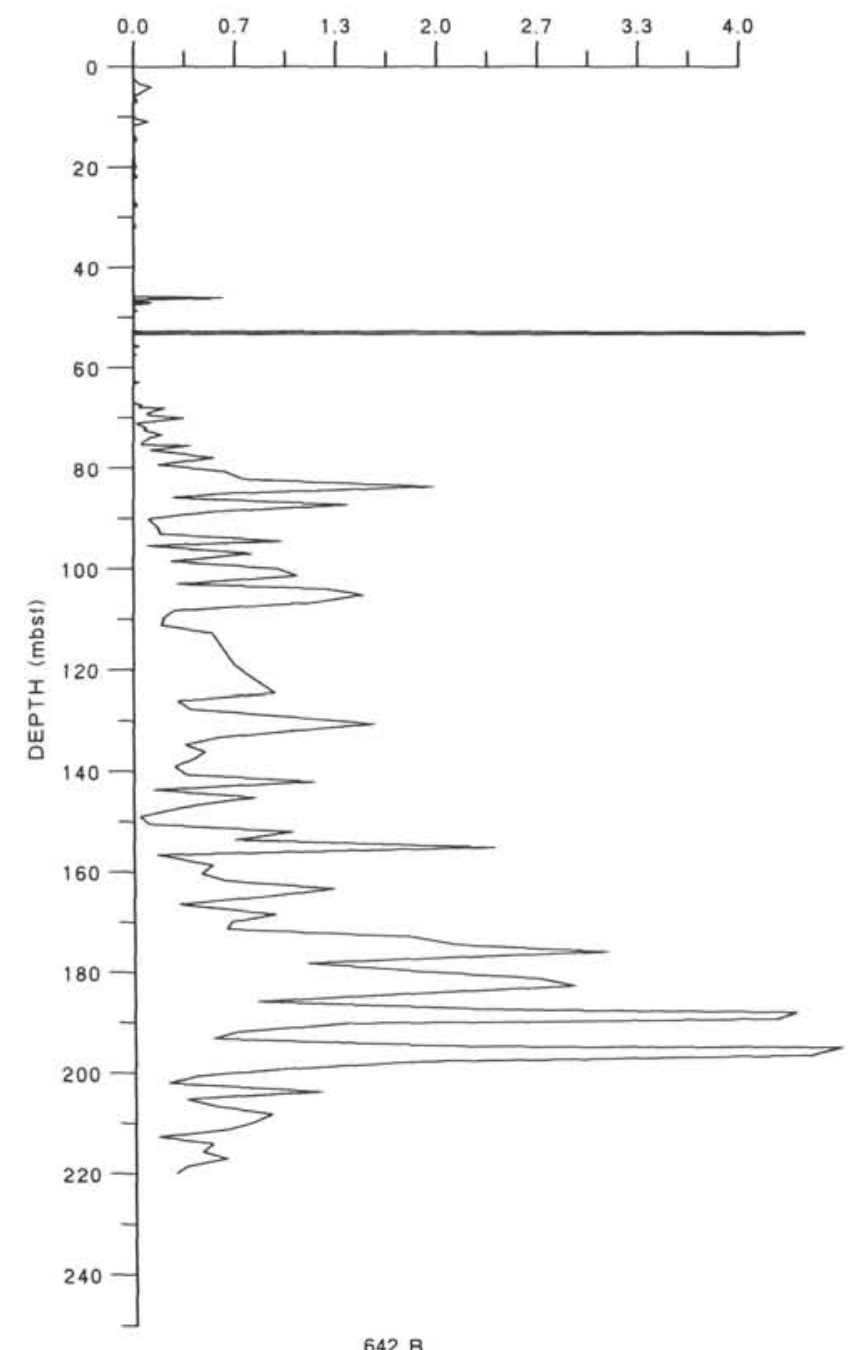

BIOGENIC OPAL, G3 (ref. to bulk weight-\%)

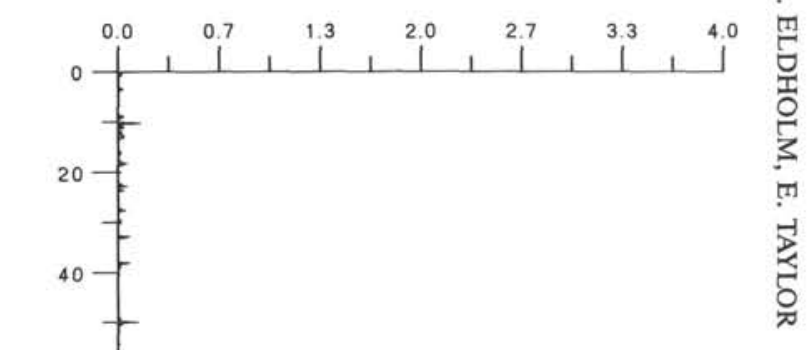

Figure 11. Concentrations of coarse-fraction biogenic opal in bulk sediments from the upper part of ODP Holes 643A, 642B, and 644A.

Che 11 Concentios of coassefracion biogic opa in bulk sedis 


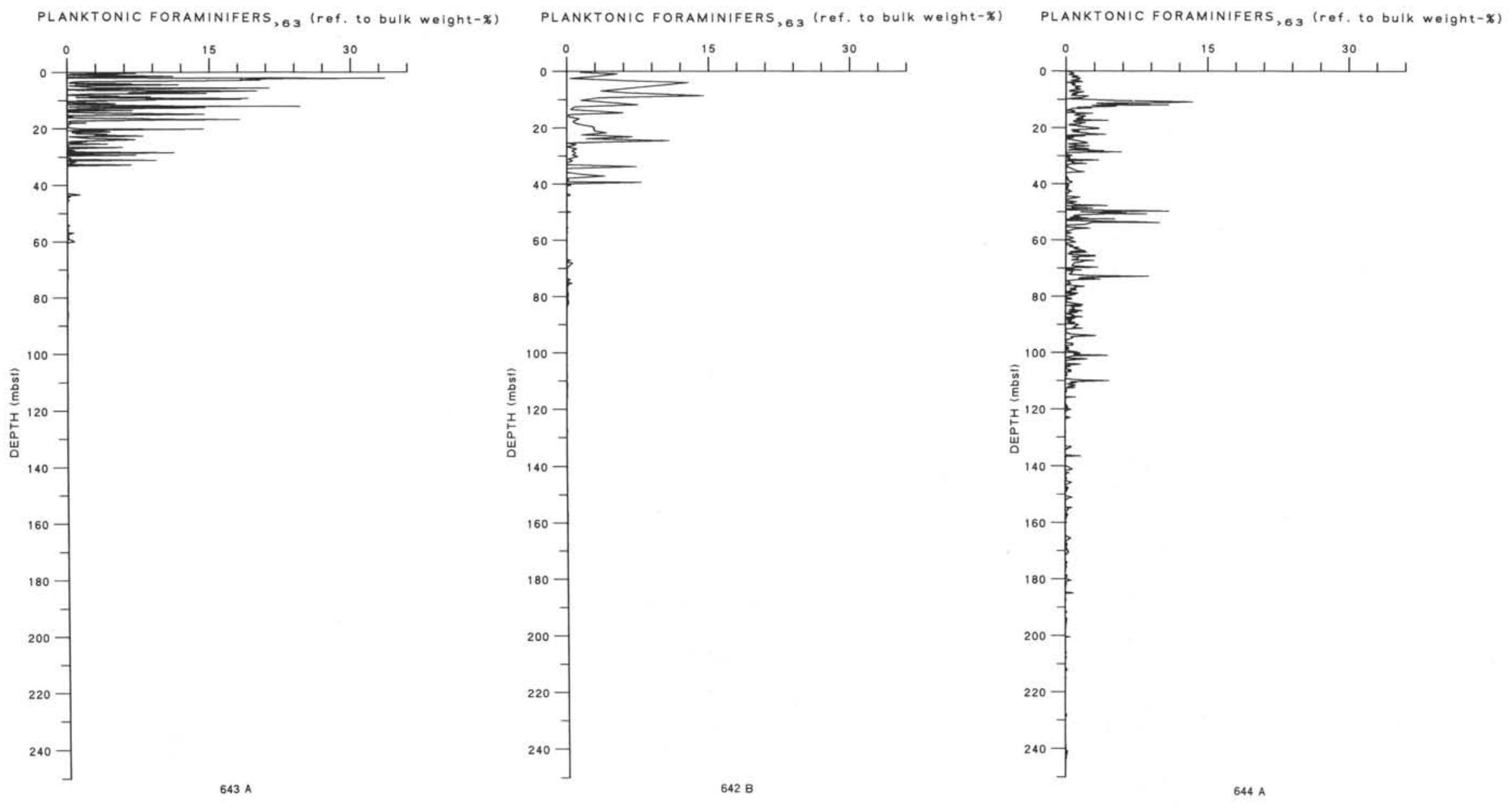

Figure 12. Concentrations of planktonic foraminifers in bulk sediments of Holes 643A, 642B, and 644A (see Henrich et al., this volume).

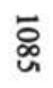


ळ

A

TERRIGEN, 63 (ref. to bulk weight- )

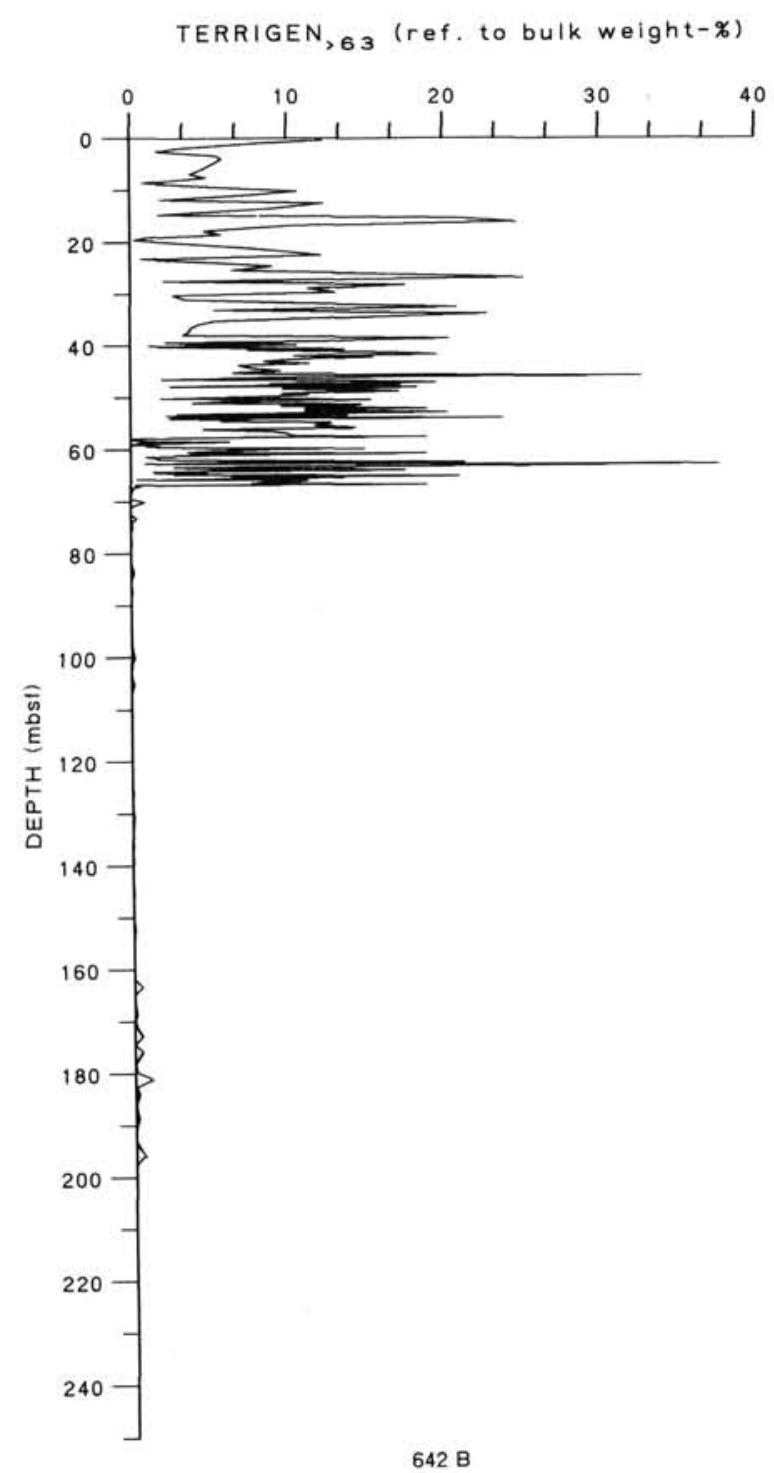

643 A
TERRIGEN, 63 (ref. to bulk weight- $\%$ )

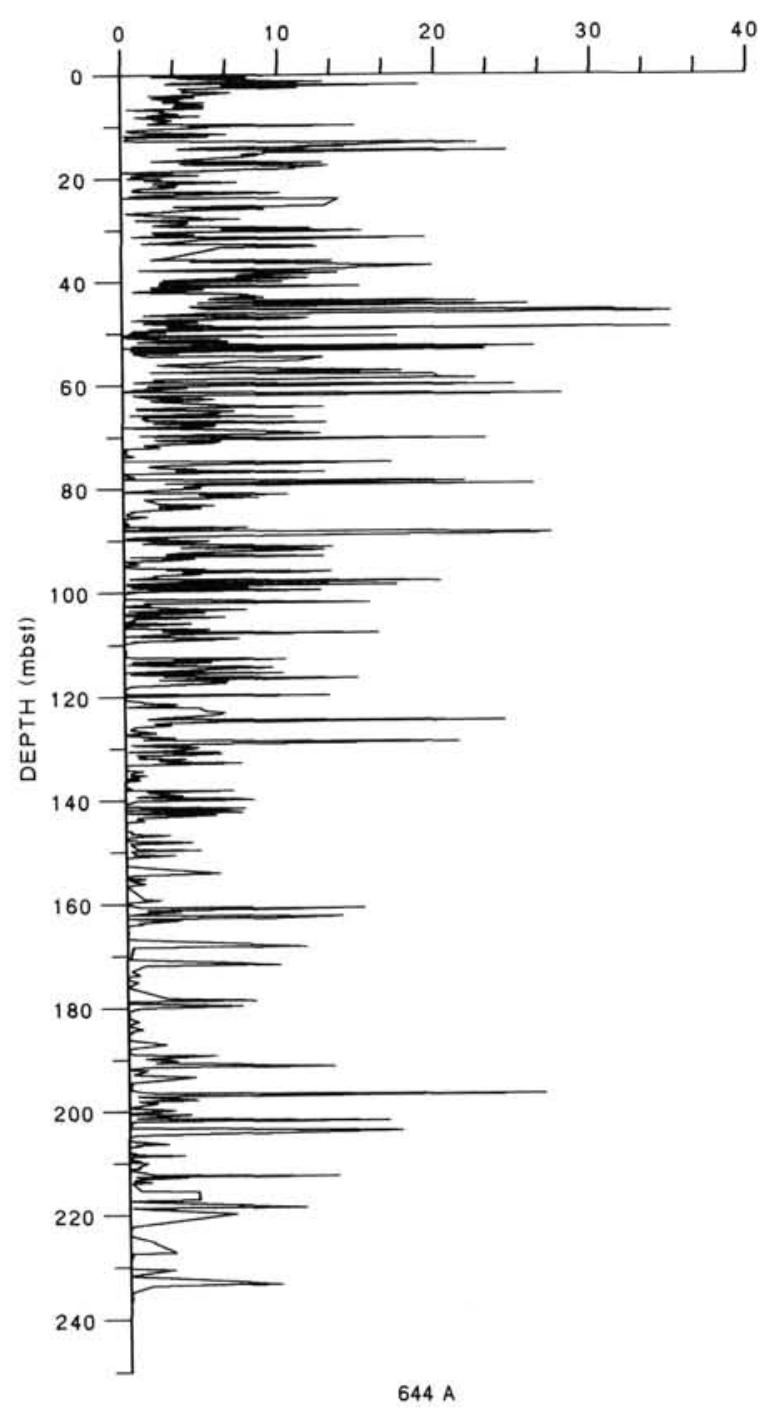

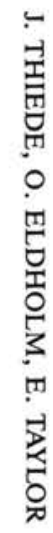


B

ROCK FRAGMENTS, 63 (ref. to weight-

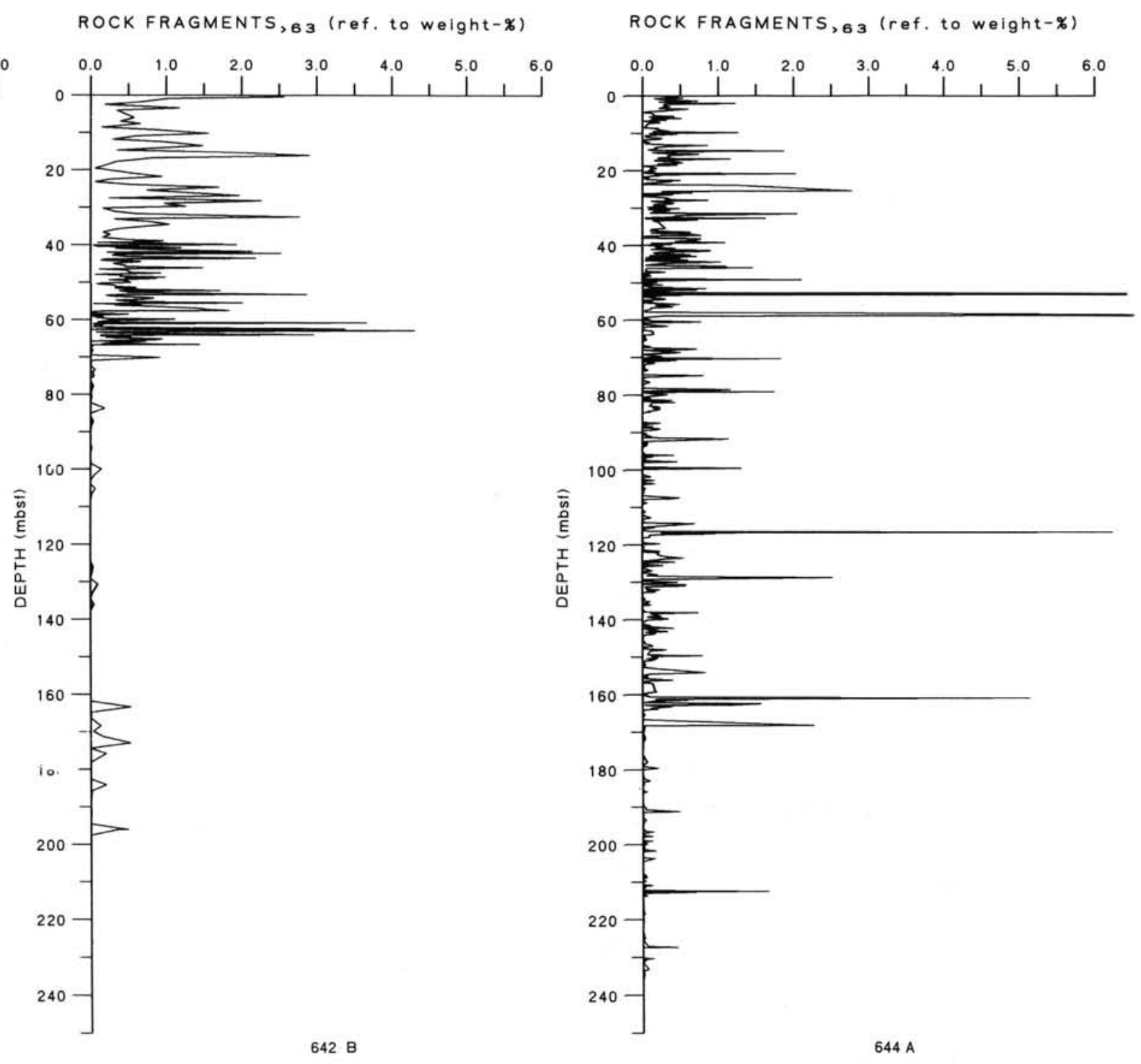

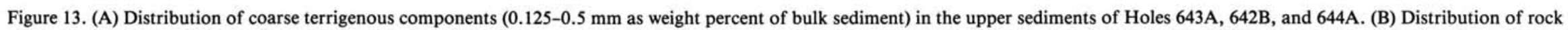
fragments $(0.125-0.5 \mathrm{~mm}$ in weight percent of bulk sediment) of the upper sediments of Holes $643 \mathrm{~A}, 642 \mathrm{~B}$, and $644 \mathrm{~A}$. For details see Henrich et al., this volume.

$\underset{\mathscr{\infty}}{\mathscr{8}}$ 
BENTHIC FORAMINIFERS, 63 (ref. to bulk weight- ) BENTHIC FORAMINIFERS, 63 (ref. to bulk weight- )

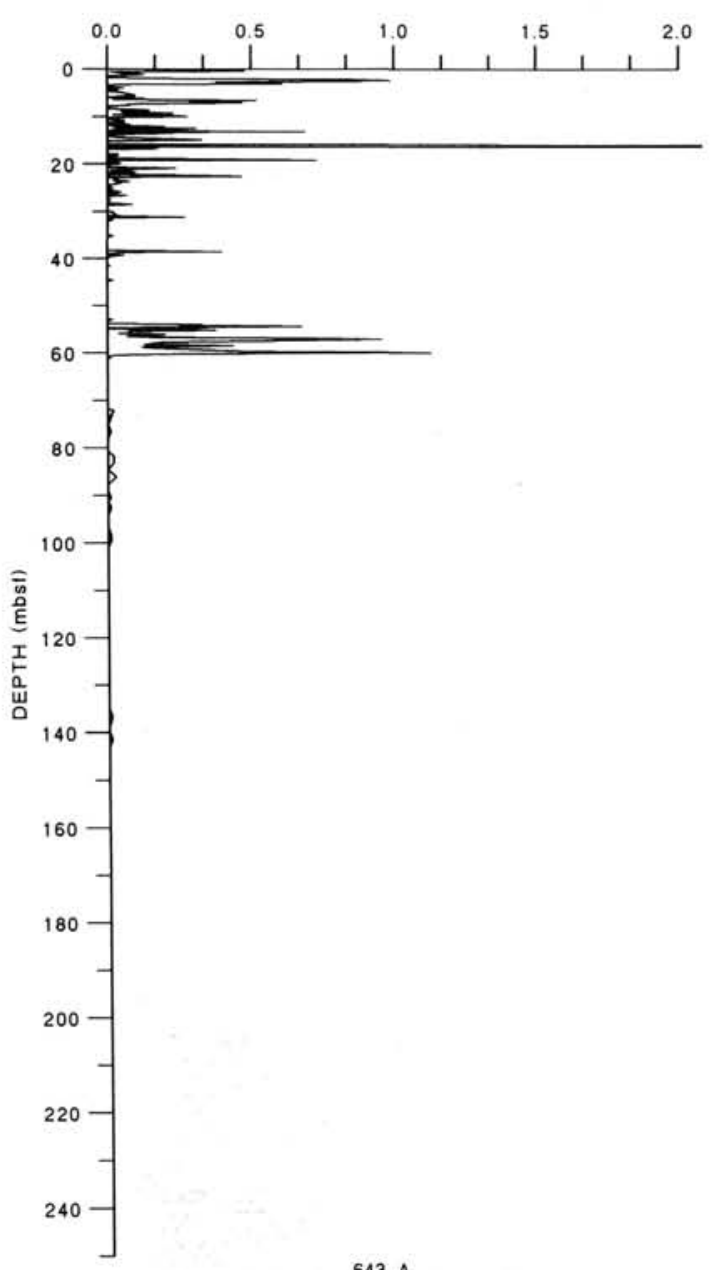

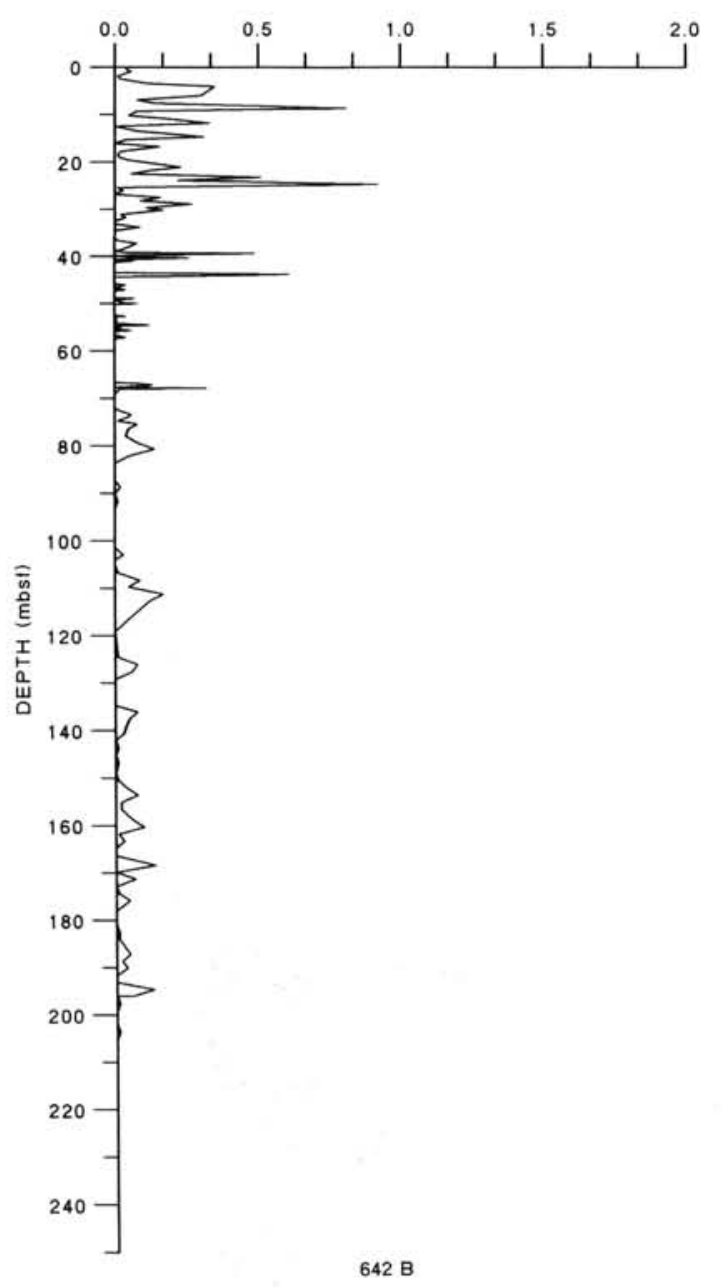

BENTHIC FORAMINIFERS, 63 (ref. to bulk weight- $\%$ )

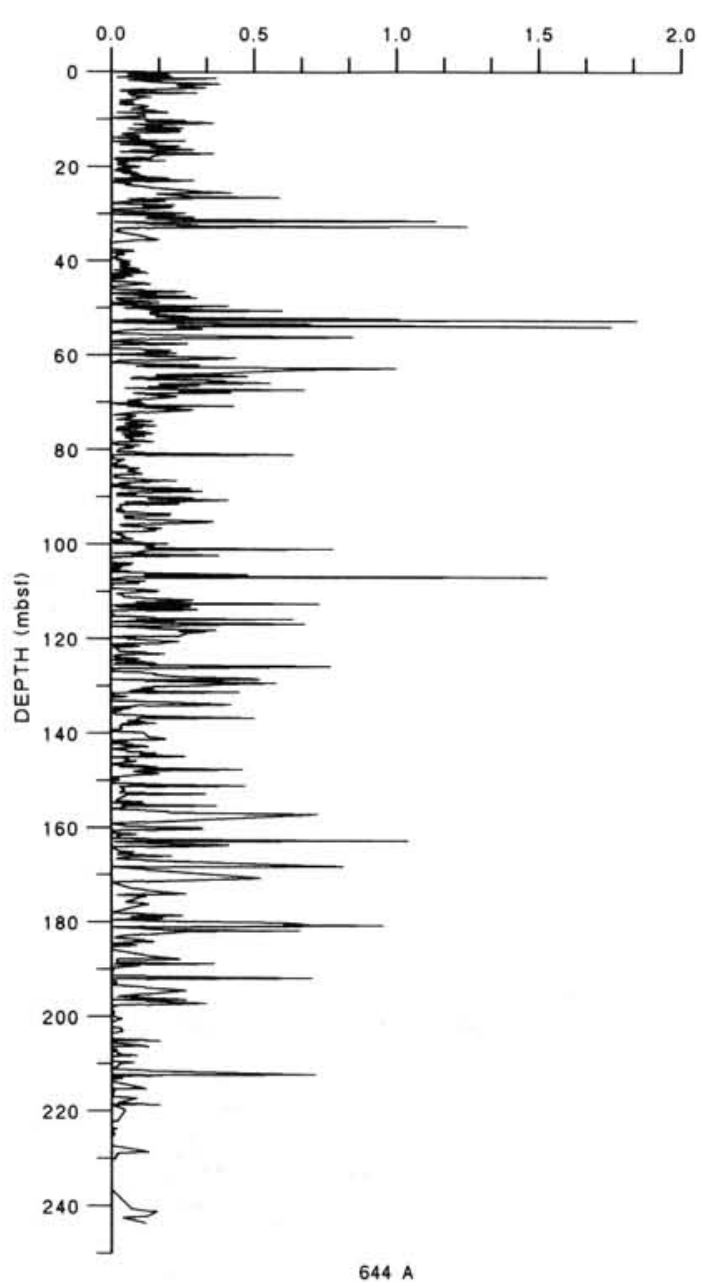

Figure 14. Distribution of benthic foraminifers in the coarse fraction $(0.125-0.500 \mathrm{~mm}$, in weight percent of bulk sediment) of Holes $643 \mathrm{~A}, 642 \mathrm{~B}$, and $644 \mathrm{~A}$ (see Henrich et al., this volume). 
A
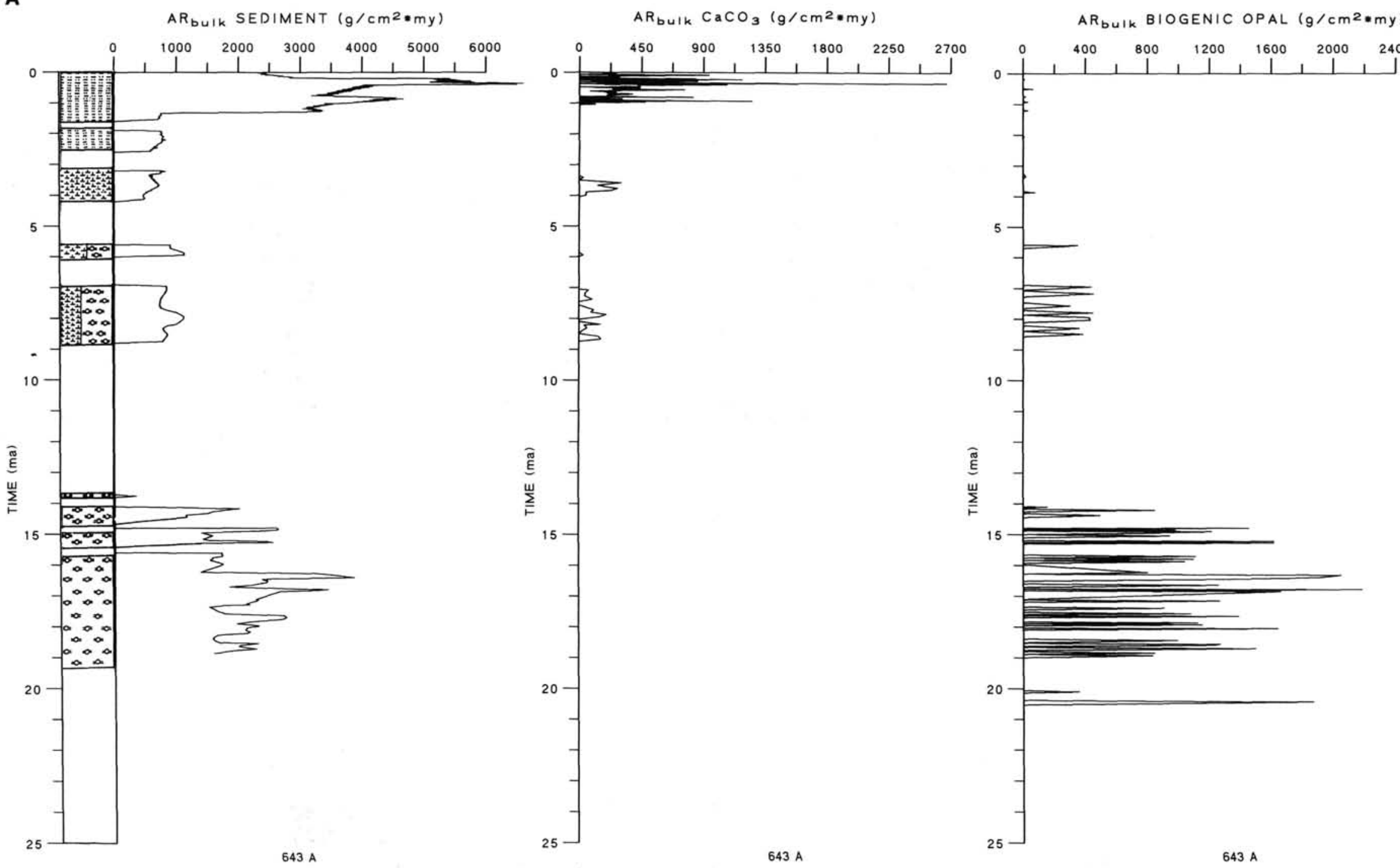

Figure 15. Hole 643A: (a) Temporal distribution of accumulation rates of bulk sediment, bulk carbonate, bulk opal, total organic carbon, and dinoflagellates/pollen/spores since 25 Ma. (b) Record since $5 \mathrm{Ma}$ for the accumulation rates of the bulk sediment, bulk coarse fraction, and coarse fraction $0.125-0.500 \mathrm{~mm}$. Sections without signature in the sediment column indicate hiatuses. 
$\overline{8}$

굴
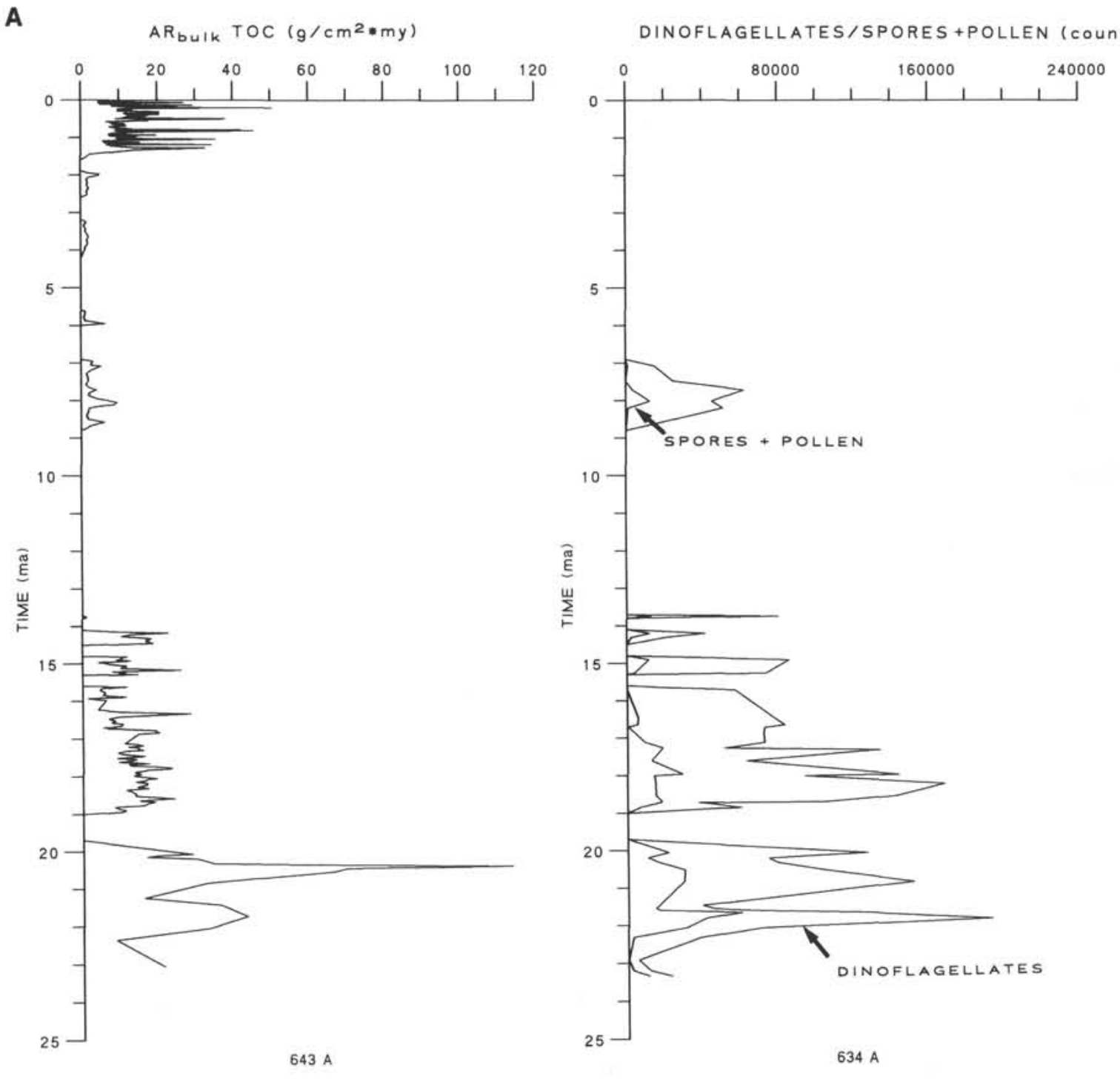
B

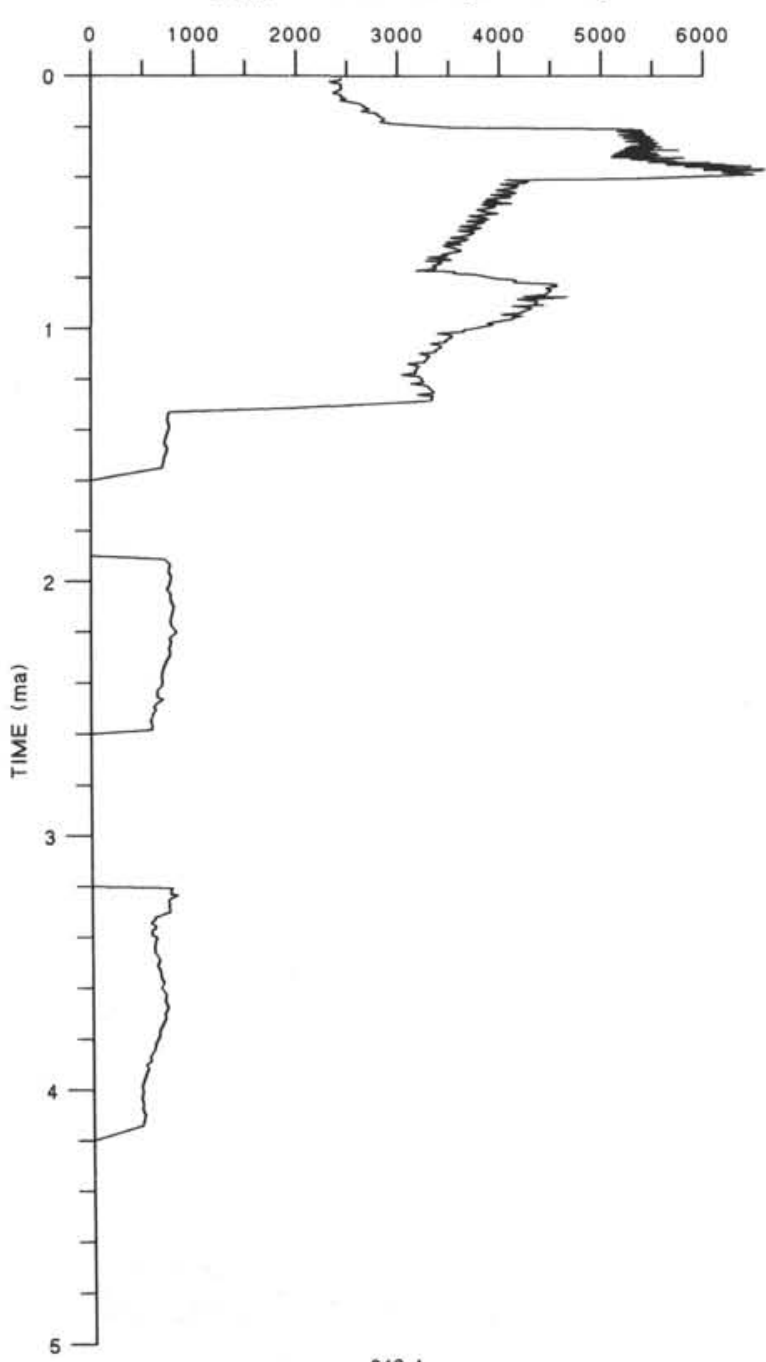

$A R, 63$ SEDIMENT $\left(g / \mathrm{cm}^{2} * \mathrm{my}\right)$

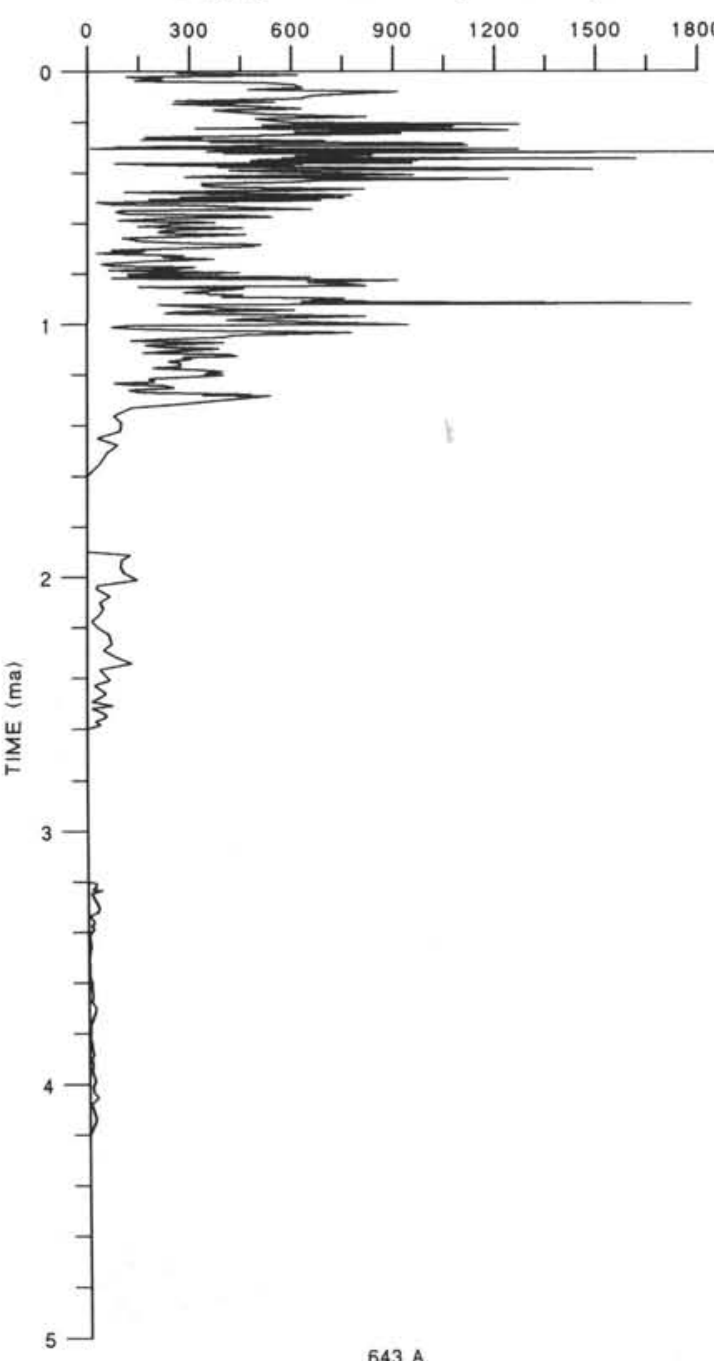

AR $125-500 \mu \mathrm{m}$ SEDIMENT $\left(\mathrm{g} / \mathrm{cm}^{2} \bullet \mathrm{my}\right)$

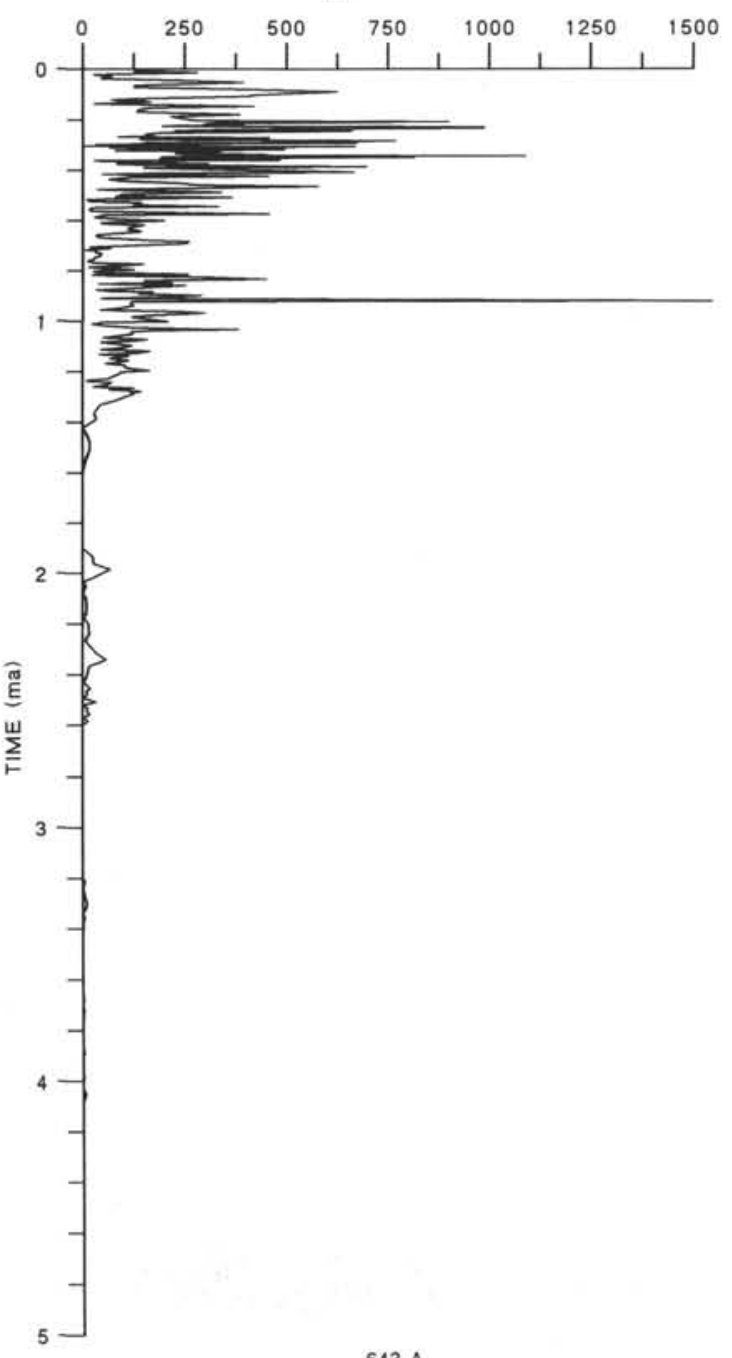

$643 \mathrm{~A}$

Figure 15 (continued). 
A

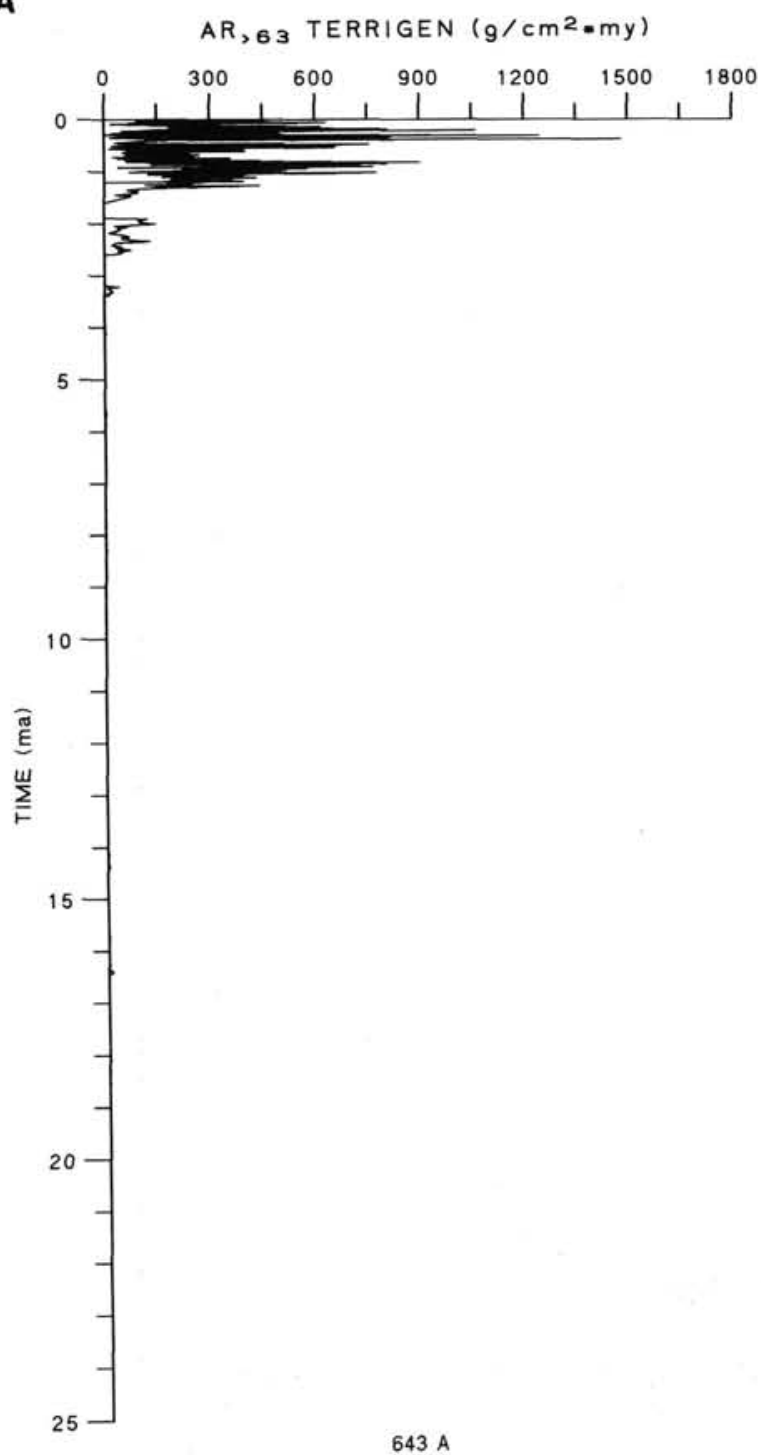

$A R, 63$ ROCK FRAGMENTS $\left(9 / \mathrm{cm}^{2} *\right.$ my $)$

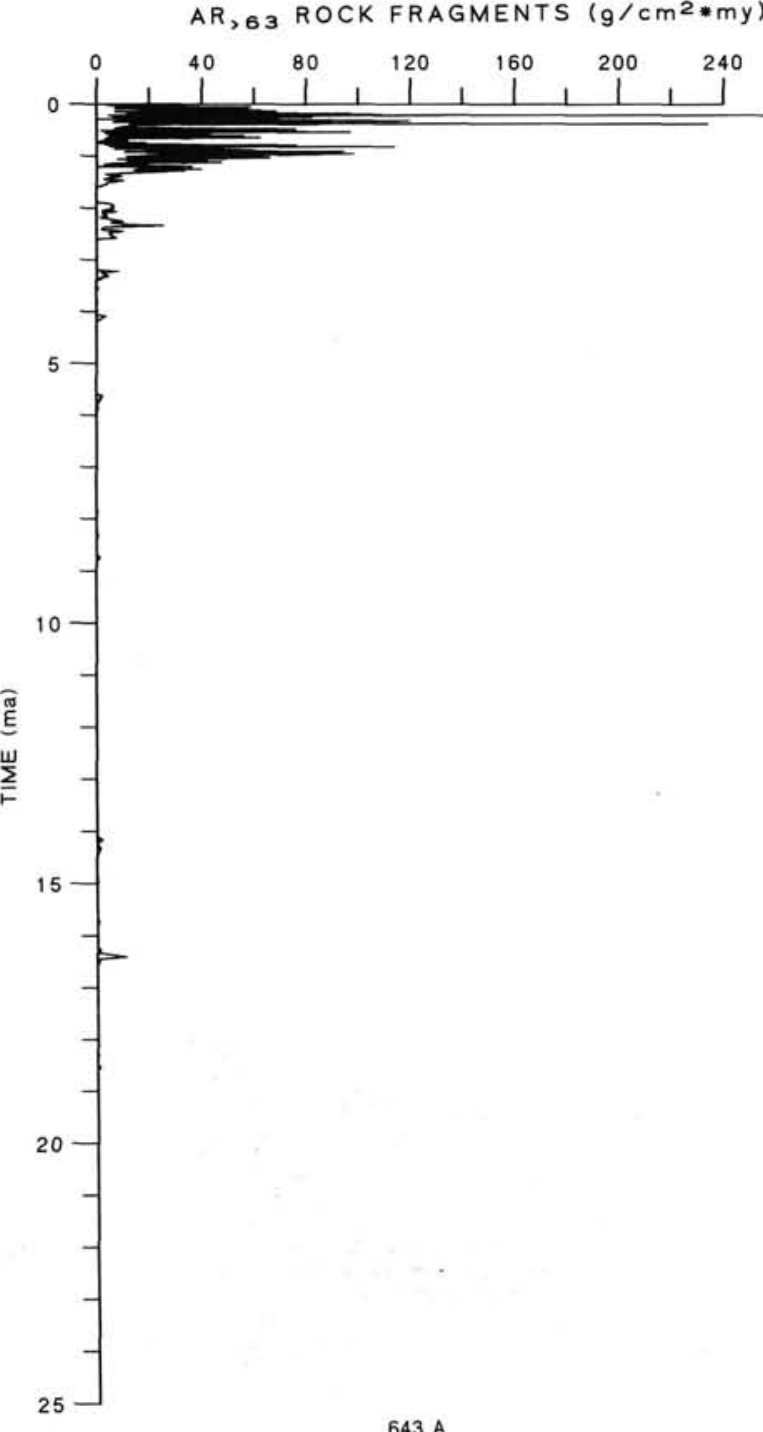

$A R, 83$ QUARTZ $\left(g / \mathrm{cm}^{2} \bullet m y\right)$

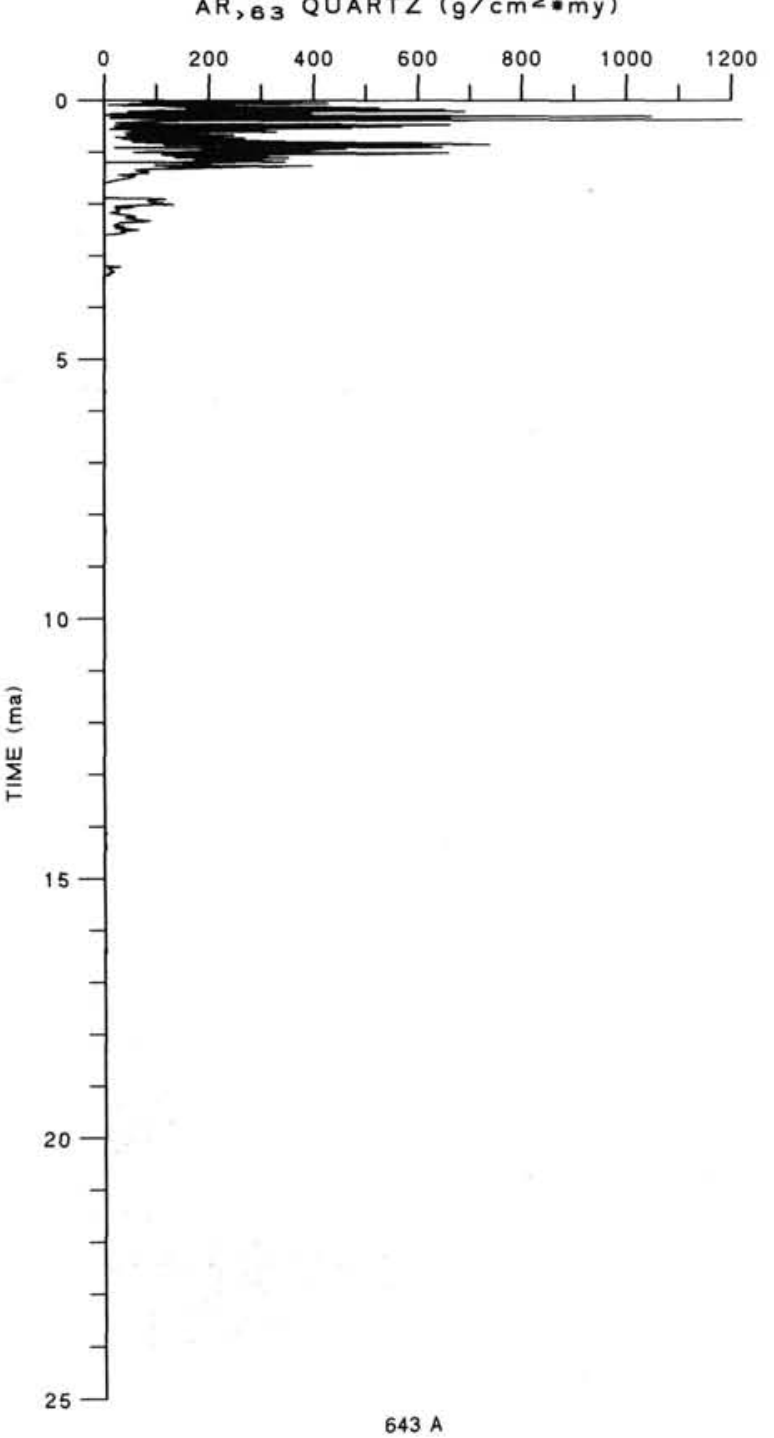


A

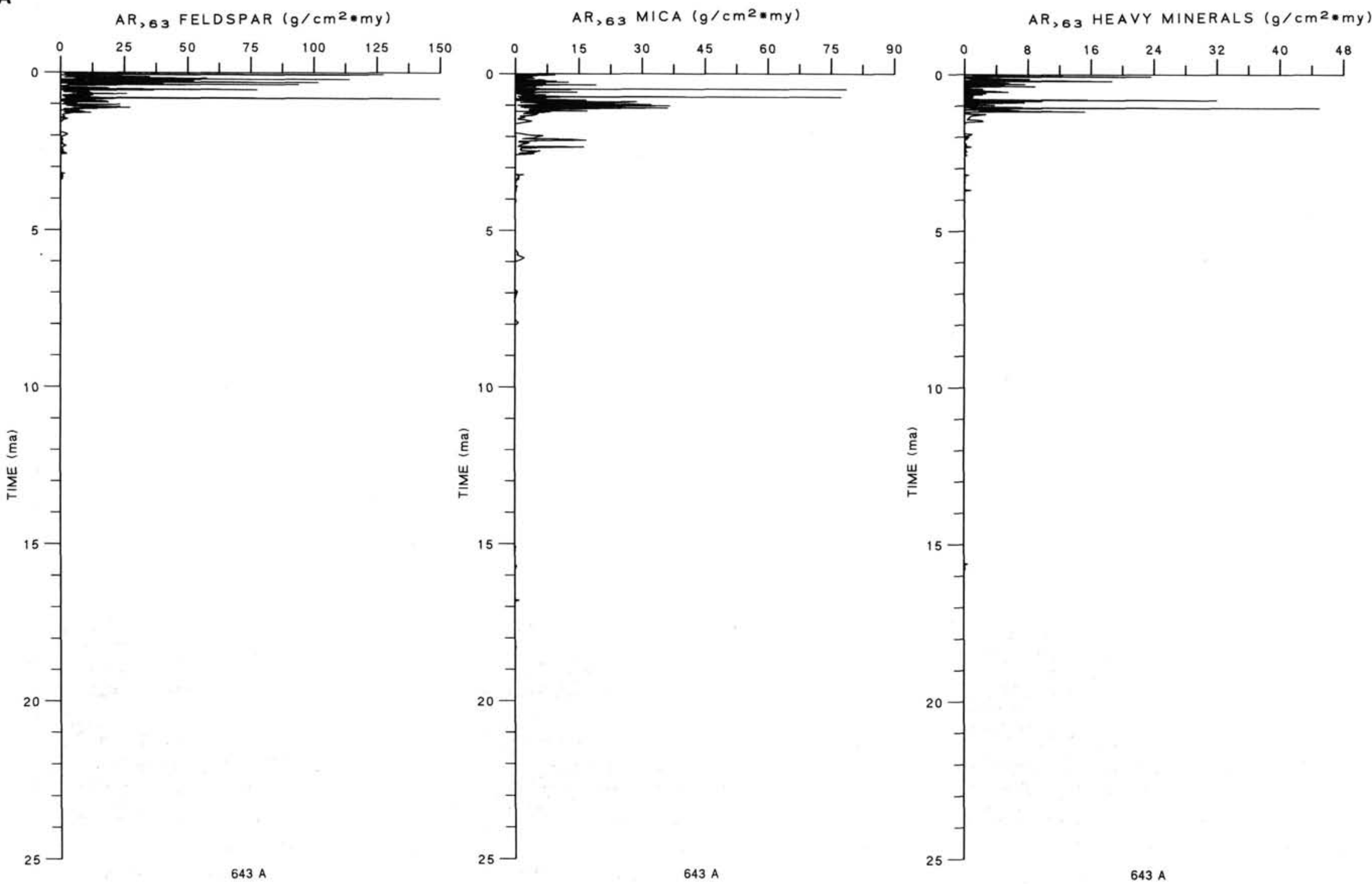

\section{$643 \mathrm{~A}$}

Figure 16. Hole 643A: (A) Accumulation rates of bulk terrigenous coarse fraction ( $>0.063 \mathrm{~mm}$ ), rock fragments, quartz grains, feldspar, mica, and heavy minerals (all the latter $0.125-0.5 \mathrm{~mm}$ ) since $25 \mathrm{Ma}$. (B) Accumulation rates of bulk terrigenous coarse fraction, rock fragments, quartz, feldspar, mica, and heavy minerals since 5 Ma. Hiatuses not indicated. Duration of hiatuses: 
B

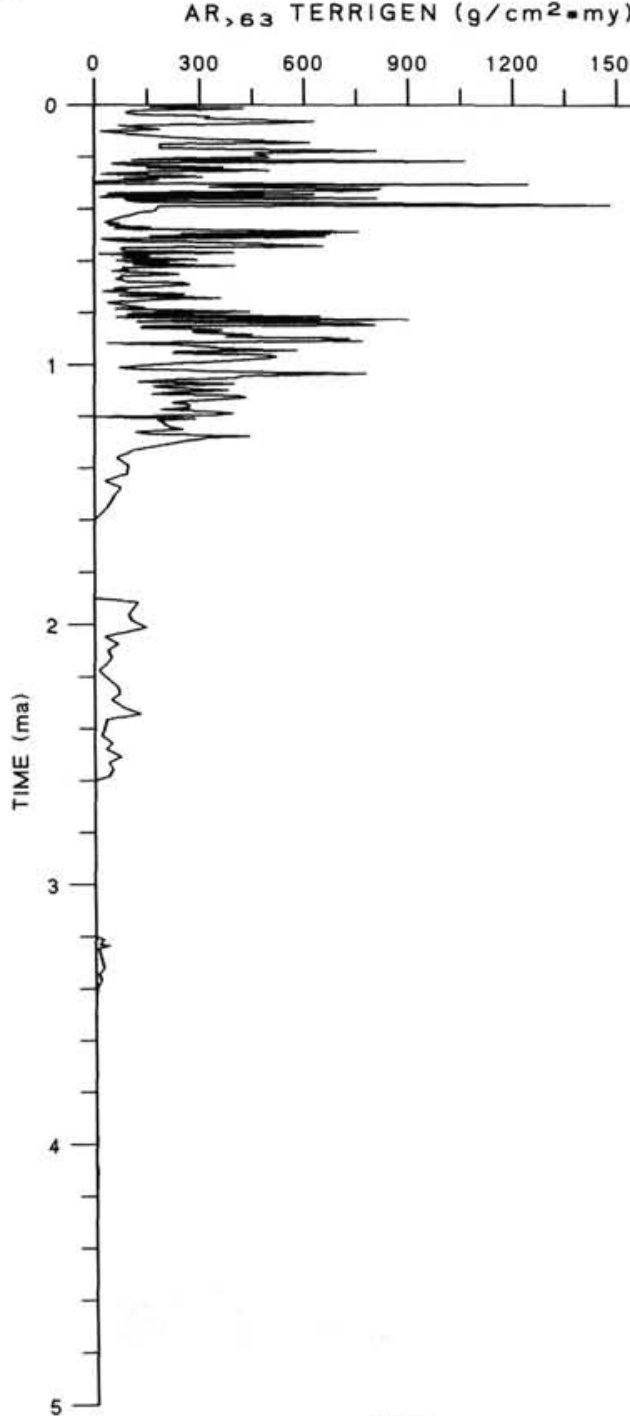

$A R, 63$ ROCK FRAGMENTS $\left(\mathrm{g} / \mathrm{cm}^{2} * m y\right)$

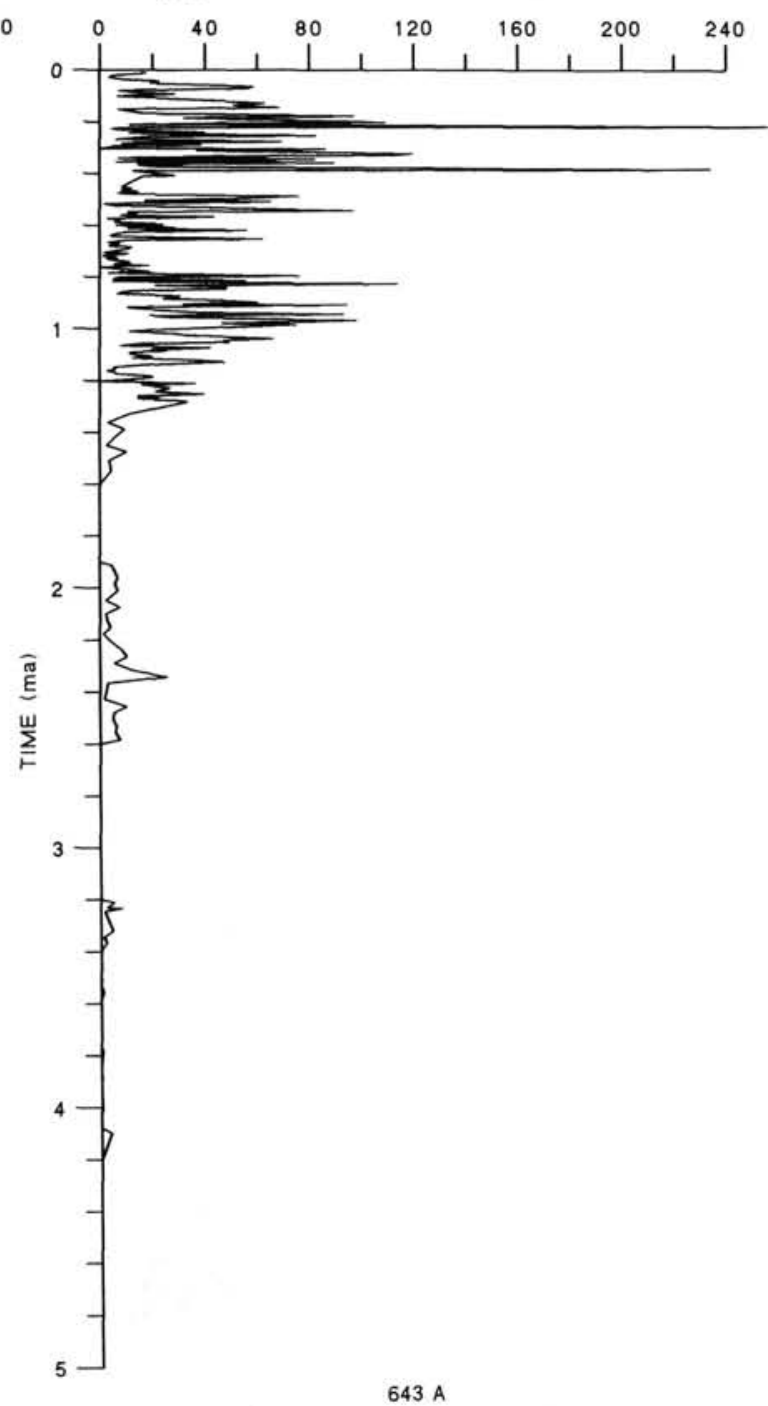

AR, 63 QUARTZ $\left(\mathrm{g} / \mathrm{cm}^{2} * m y\right)$

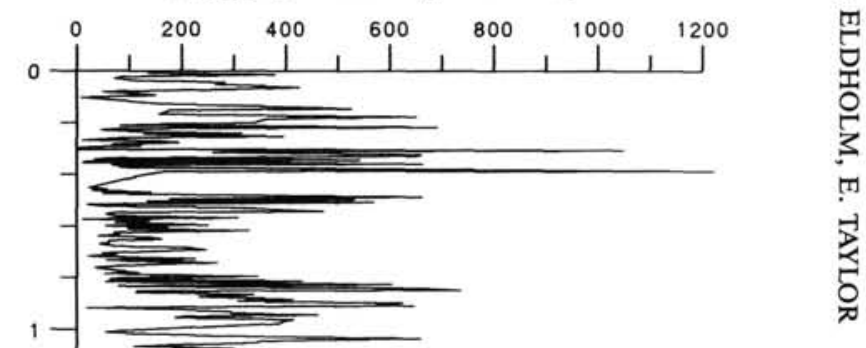


B

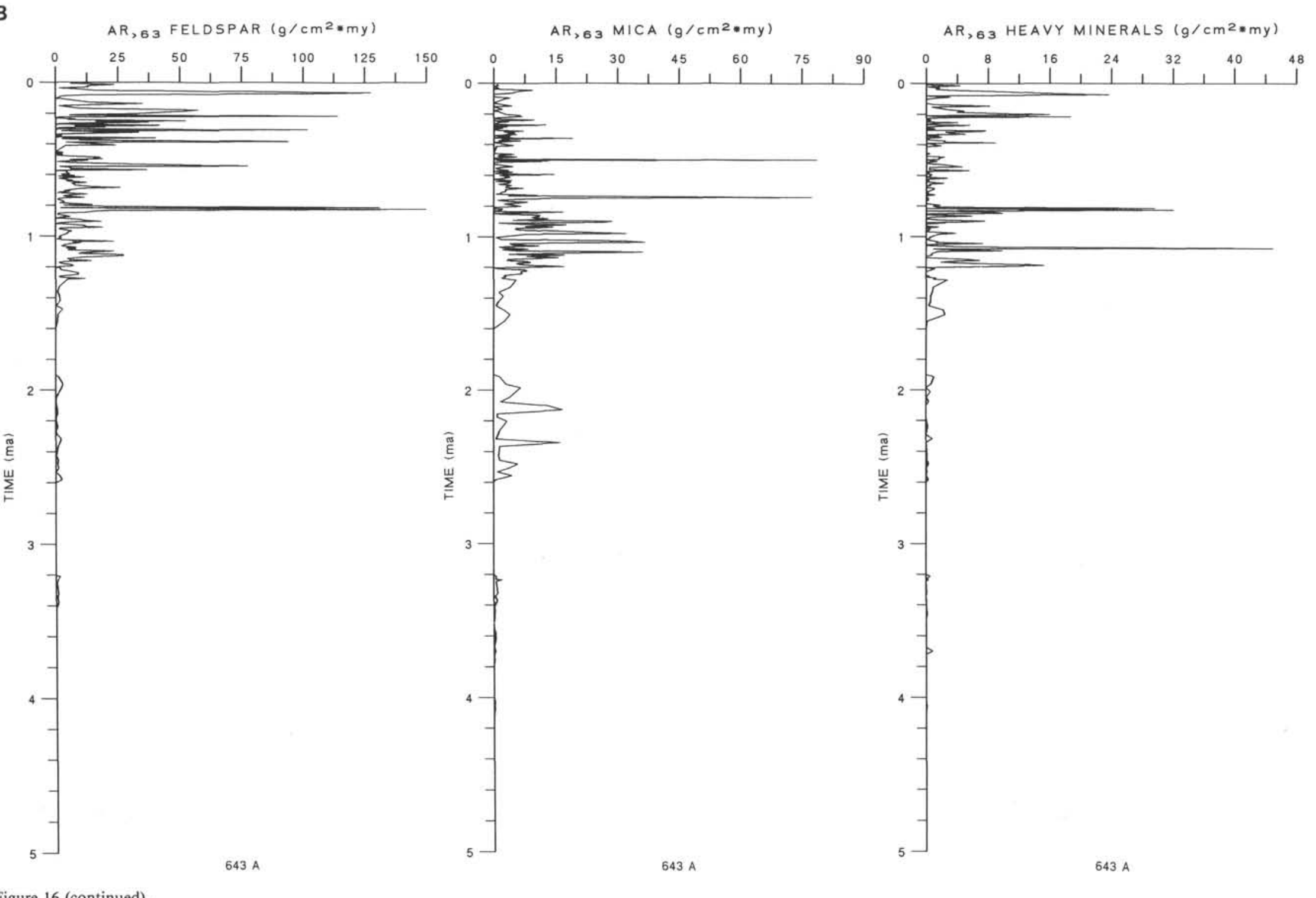

Figure 16 (continued)

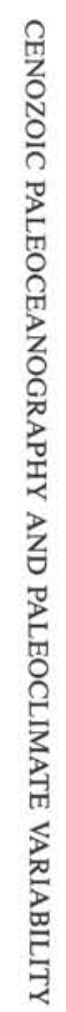




$$
F=
$$




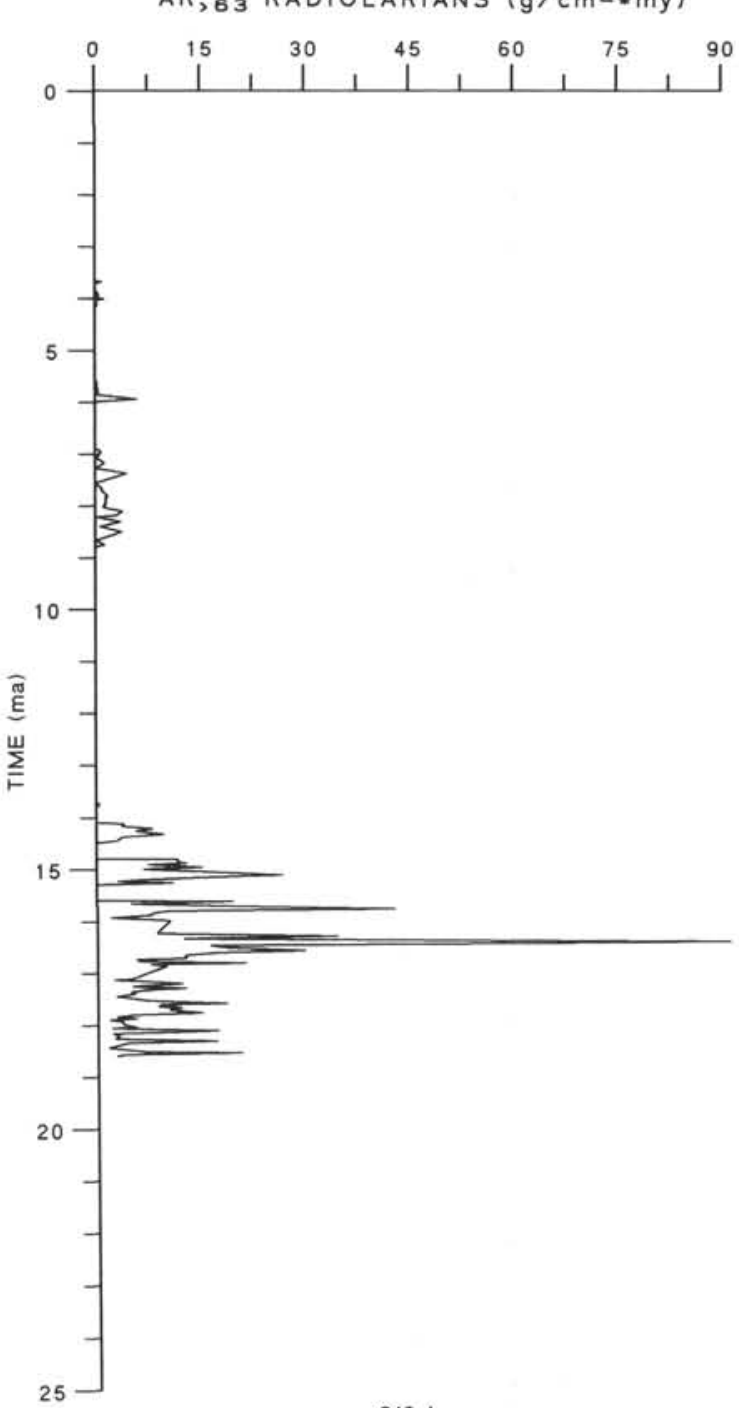

$A R, 63$ PLANKTON $\left(g / \mathrm{cm}^{2} \cdot \mathrm{my}\right)$

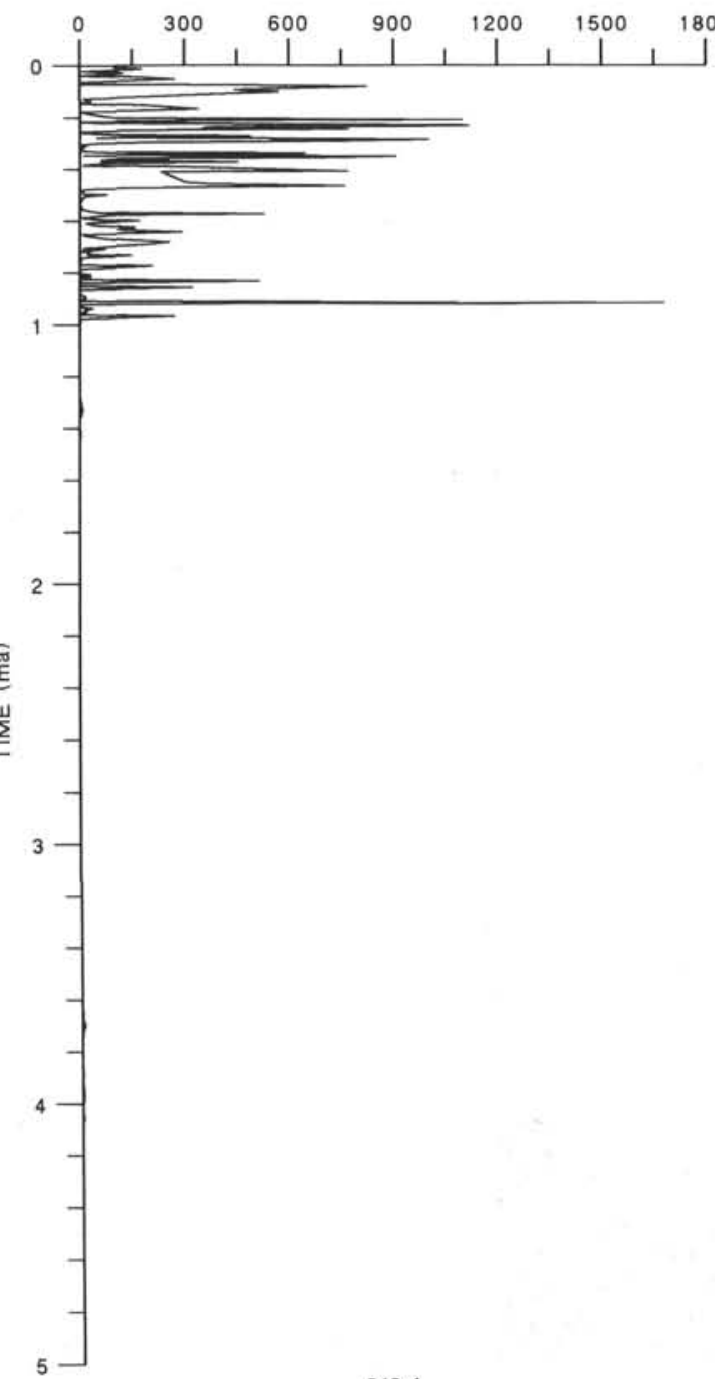

$643 \mathrm{~A}$
$A R, 63$ DIATOMS $\left(g / \mathrm{cm}^{2} \bullet \mathrm{my}\right)$

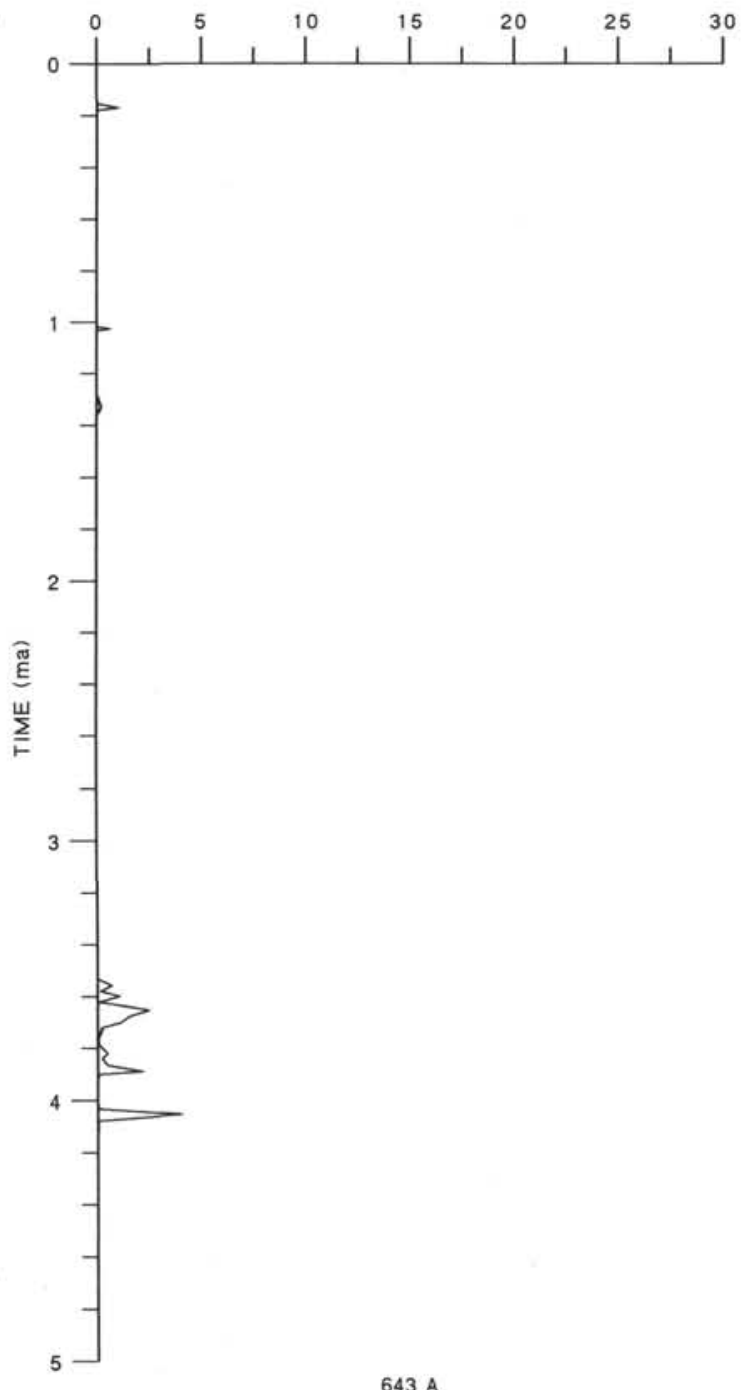

$643 \mathrm{~A}$

Figure 17. Hole 643A: (A) Accumulation rates of sediment components $>0.063 \mathrm{~mm}$ : Total plankton, diatoms, planktonic foraminifers, and radiolarians (all the latter in $0.125-0.5 \mathrm{~mm}$ ) since $25 \mathrm{Ma}$ (B) Accumulation rates of sediment components $>0.063 \mathrm{~mm}$ : Total plankton, diatoms, radiolarians, and planktonic foraminifers since $5 \mathrm{Ma}$. Hiatuses not indicated. Duration of hiatuses: com- 
B

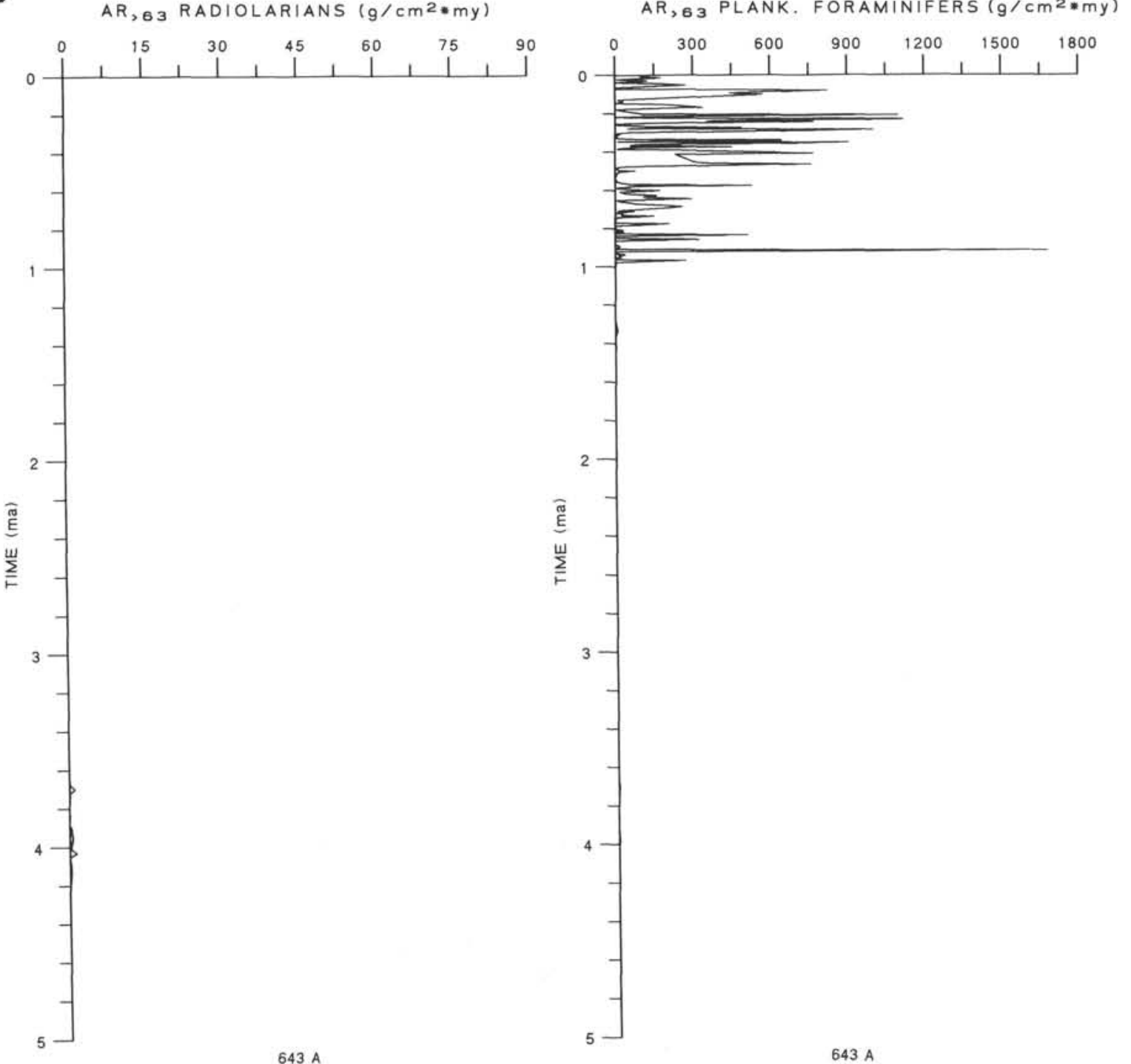

Figure 17 (continued). 
A

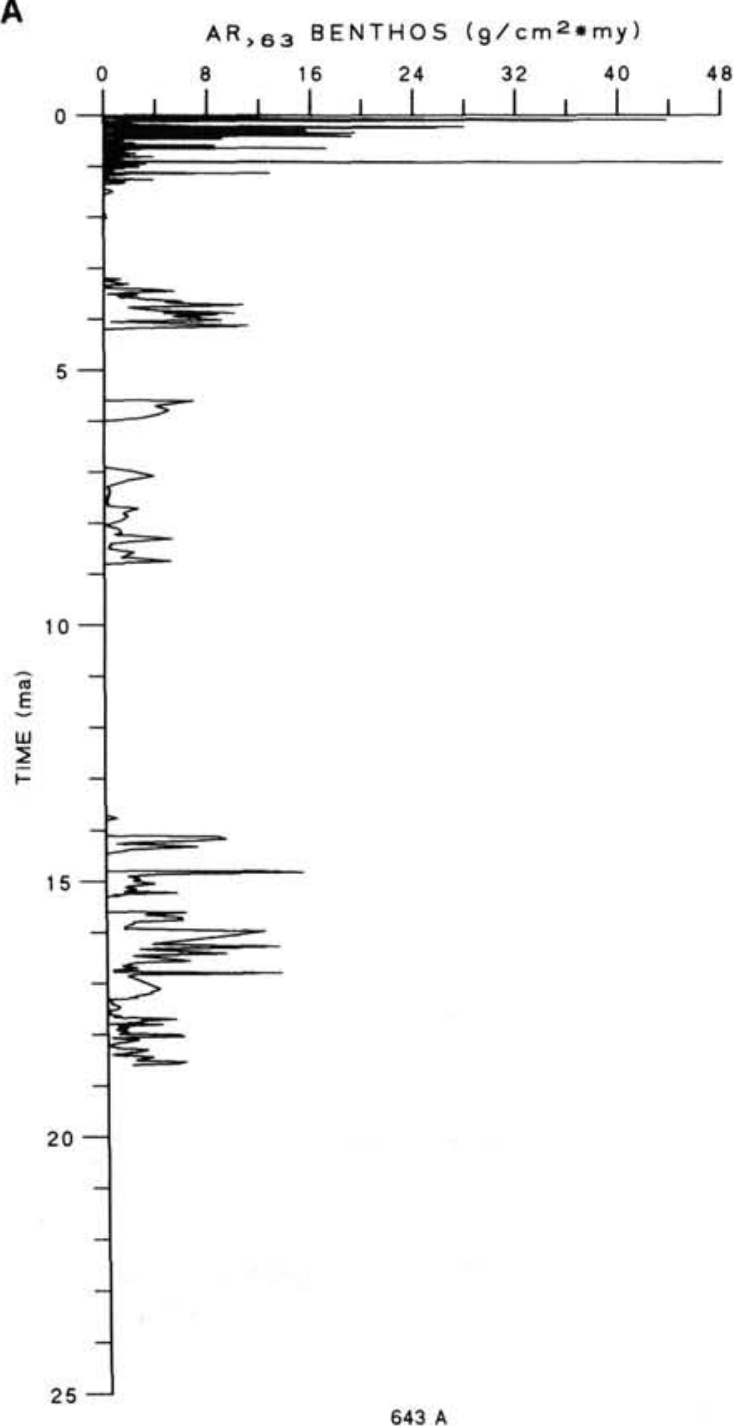

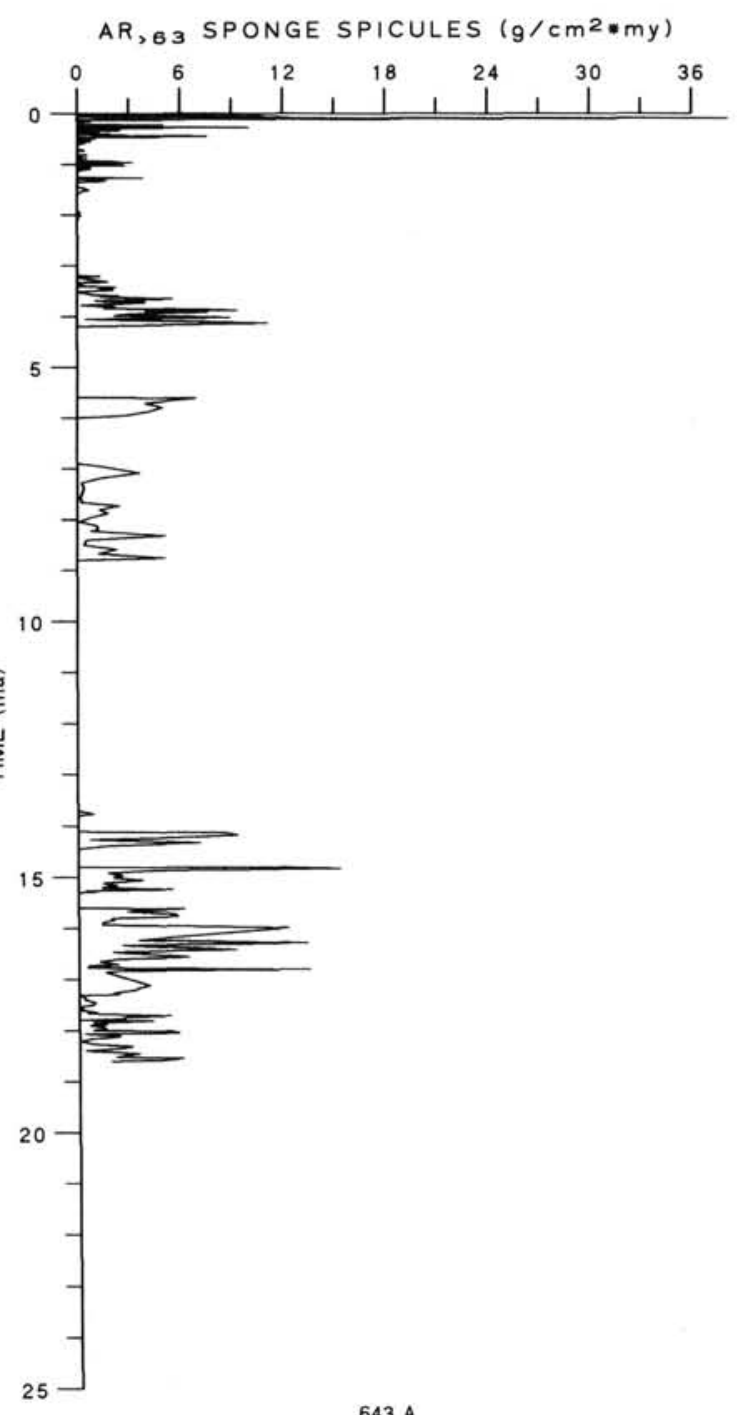

AR,63 BENTHIC FORAMINIFERS $\left(g / \mathrm{cm}^{2} * m y\right)$

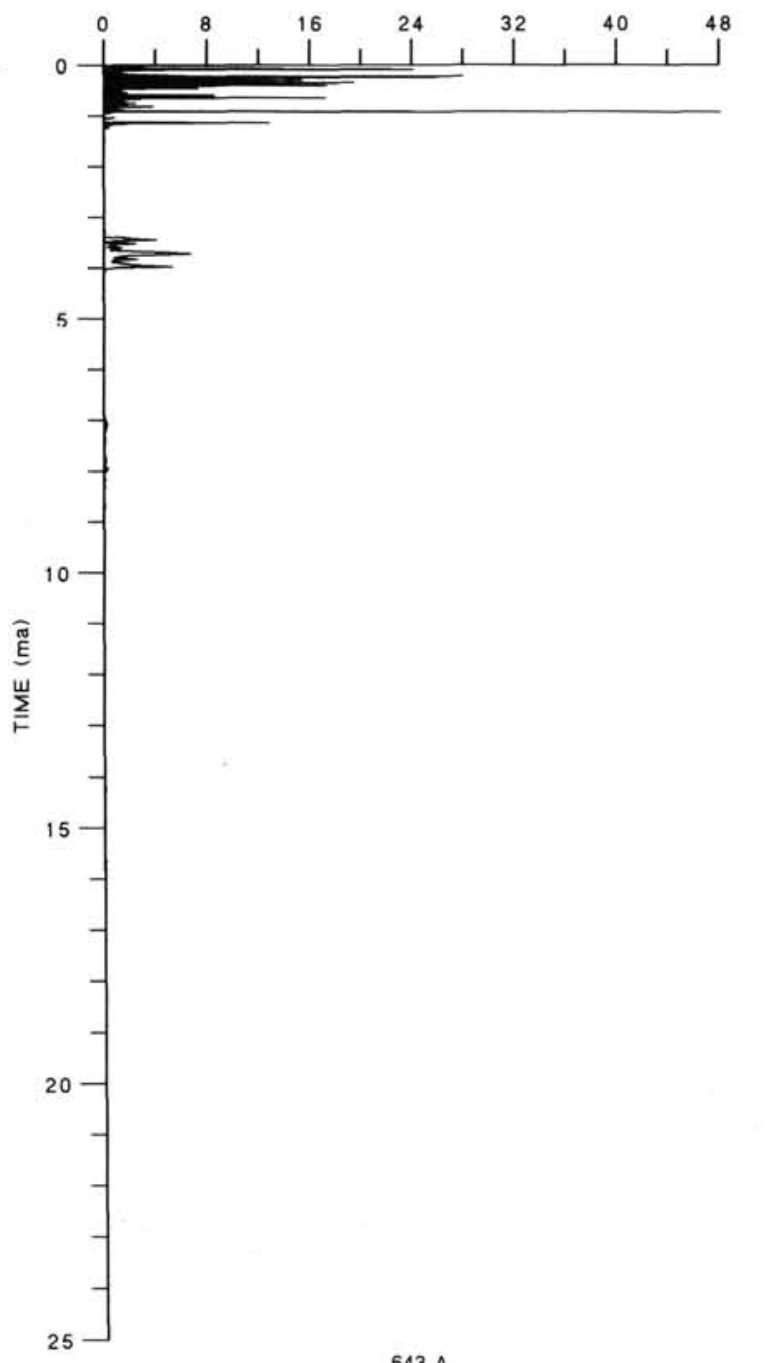

$643 \mathrm{~A}$

Figure 18. Hole 643A: (A) Accumulation rates of bulk benthos, sponge spicules, and benthic foraminifers (all $>0.063 \mathrm{~mm}$ ) since $25 \mathrm{Ma}$. (B) Accumulation rates of bulk benthos, sponge spicules, and benthic foraminifers since $5 \mathrm{Ma}$ (details of a). Hiatuses not indicated. Duration of hiatuses: compare Figure 15. 
$\overline{8}$

B

$$
\text { AR ,63 BENTHOS }\left(g / \mathrm{cm}^{2} * m y\right) \quad \text { AR, } 33 \text { SPONGE SPICULES }\left(\mathrm{g} / \mathrm{cm}^{2} * \mathrm{my}\right)
$$

AR, 63 BENTHIC FORAMINIFERS $\left(g / \mathrm{cm}^{2}=\mathrm{my}\right)$
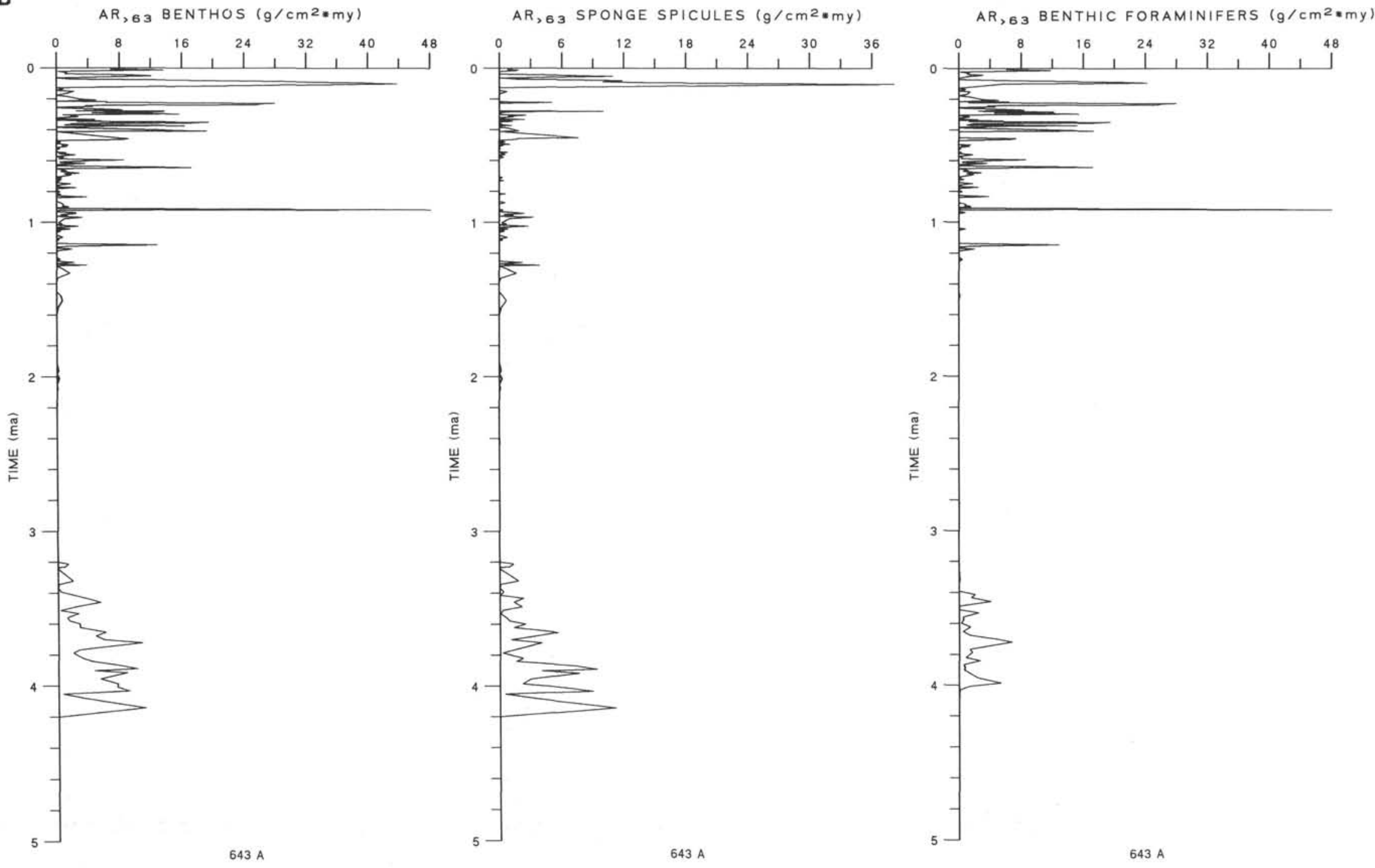

굴

Figure 18 (continued). 

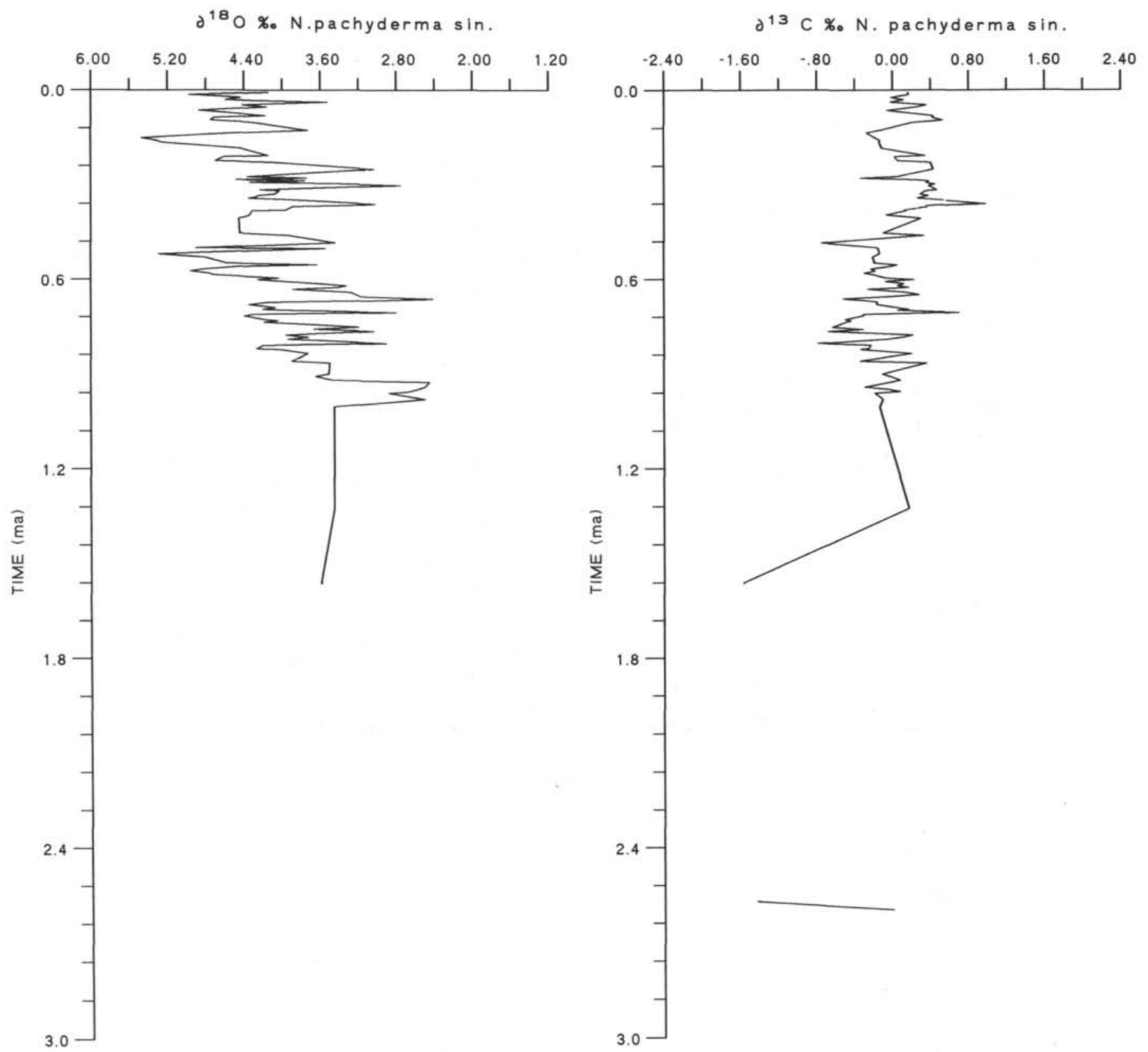

Figure 19. Site 643 stable oxygen and carbon isotope ratios since $3 \mathrm{Ma}$. Data from measurements of Neogloboquadrina pachyderma (see Jansen et al., this volume). 
A

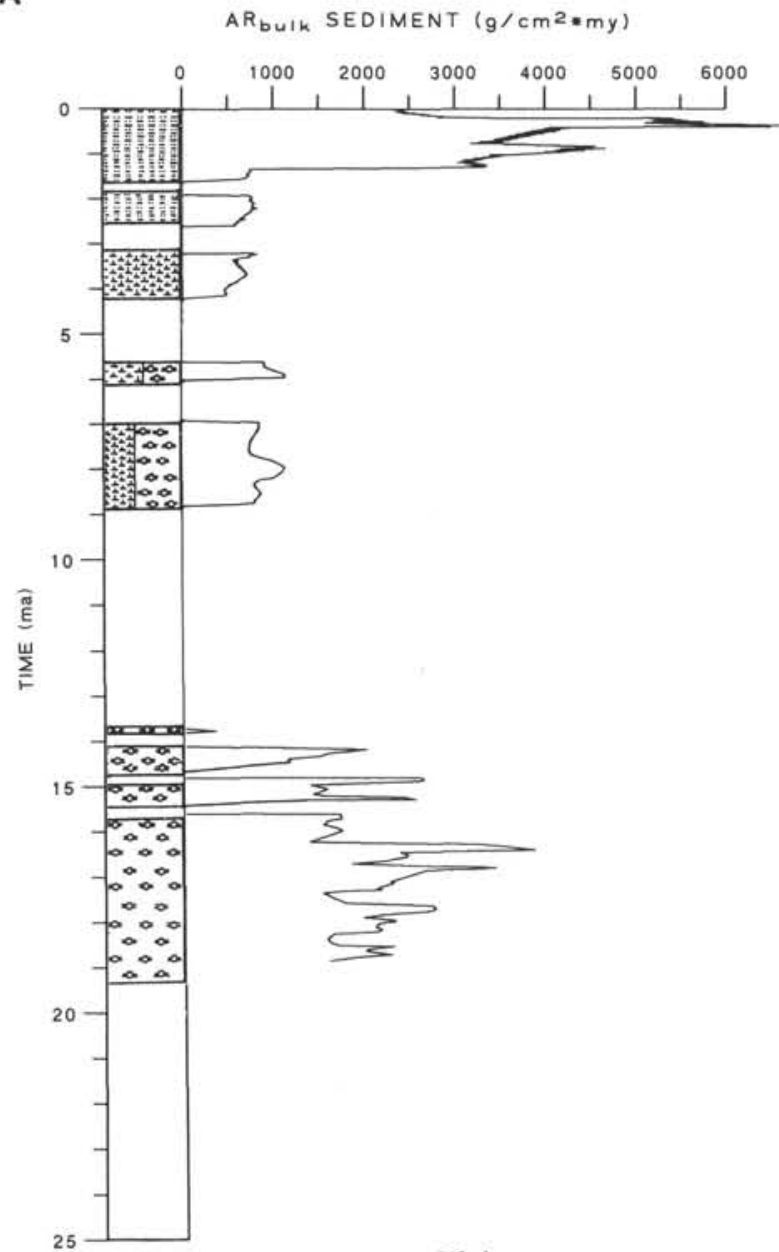

AR buIK SEDIMENT $\left(g / \mathrm{cm}^{2} \cdot \mathrm{my}\right)$

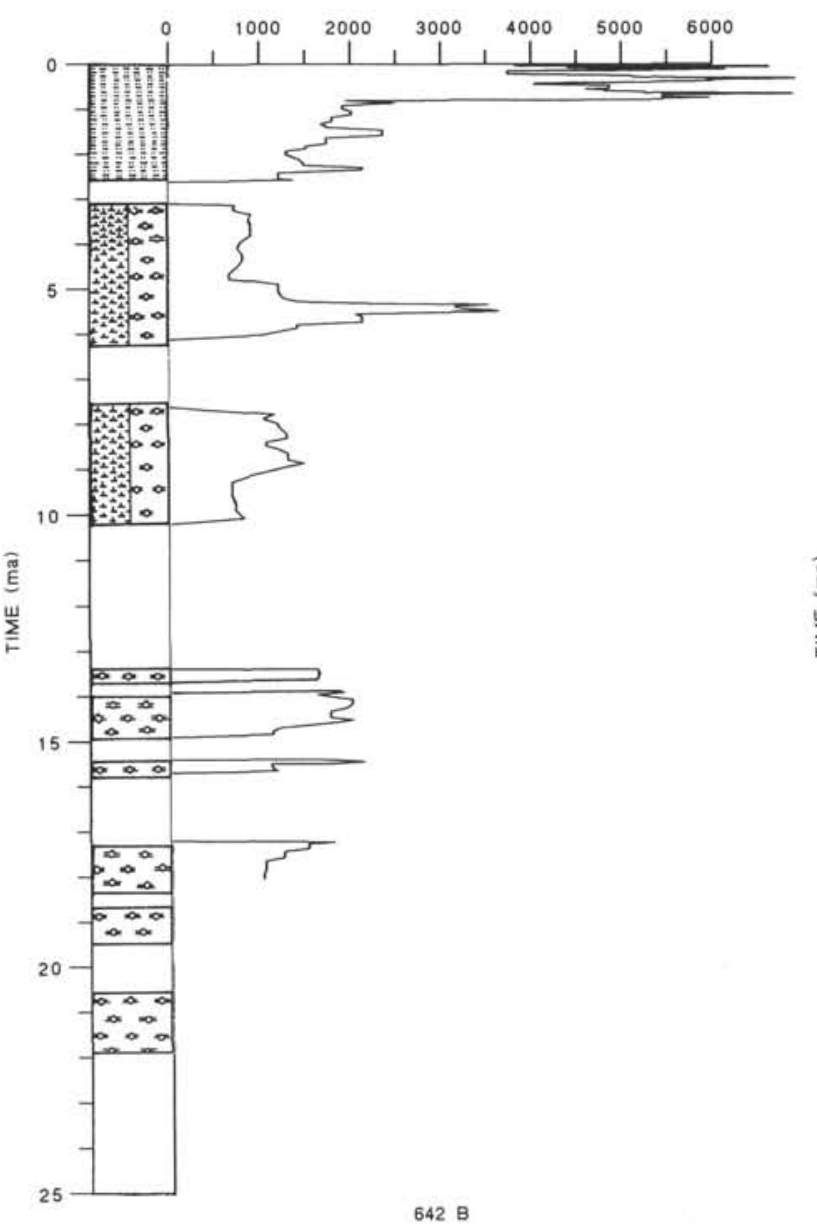

642 B
AR SEDIMENT $\left(g / \mathrm{cm}^{2} \bullet \mathrm{my}\right)$

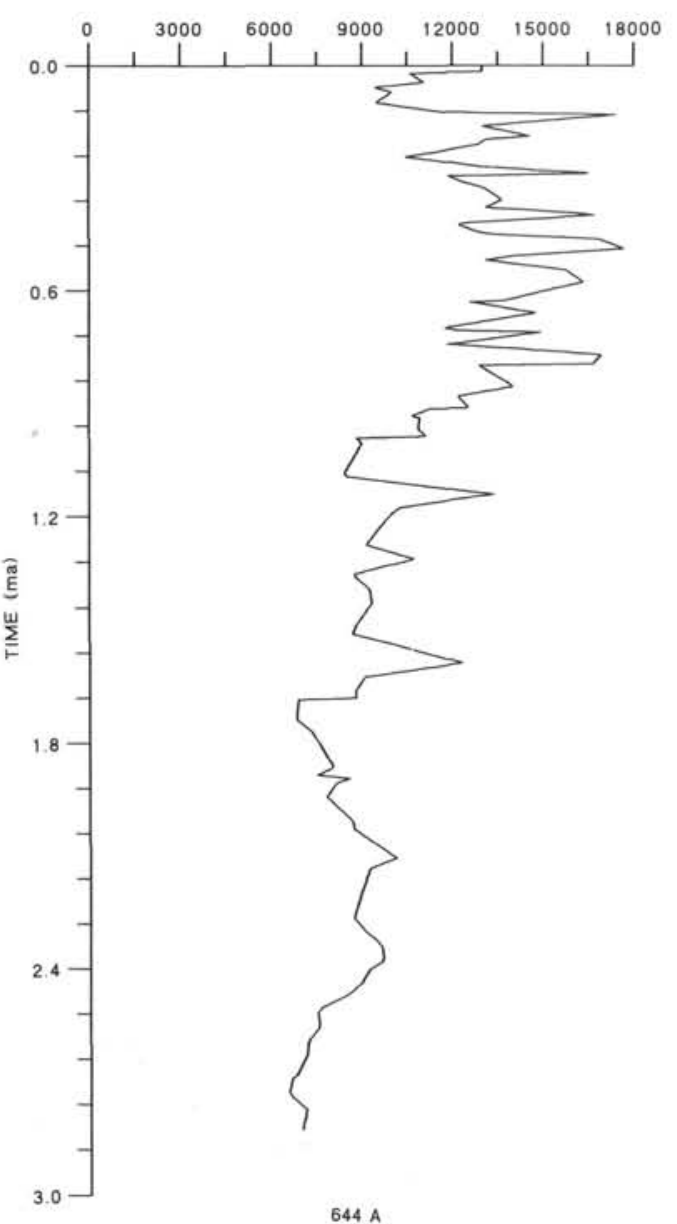

543 
B

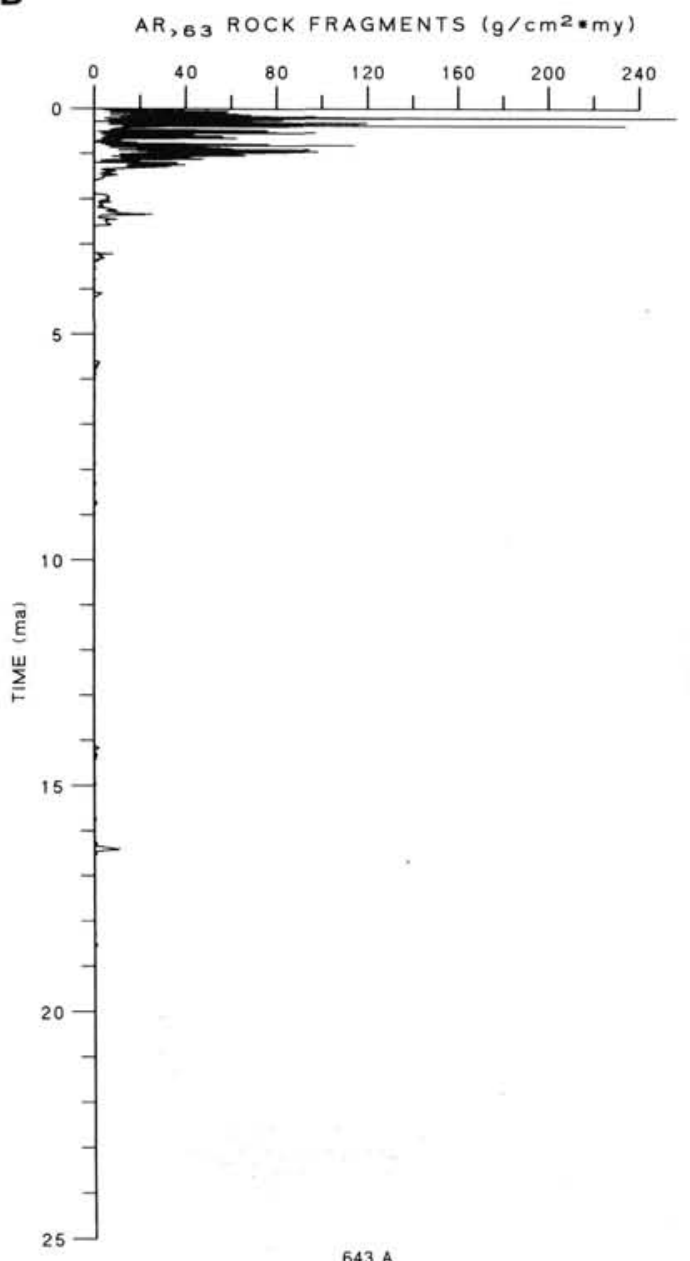

$A R, 63$ ROCK FRAGMENTS $\left(g / \mathrm{cm}^{2} \cdot m y\right)$

AR,, ROCK FRAGMENTS $\left(g / \mathrm{cm}^{2} \bullet \mathrm{my}\right)$
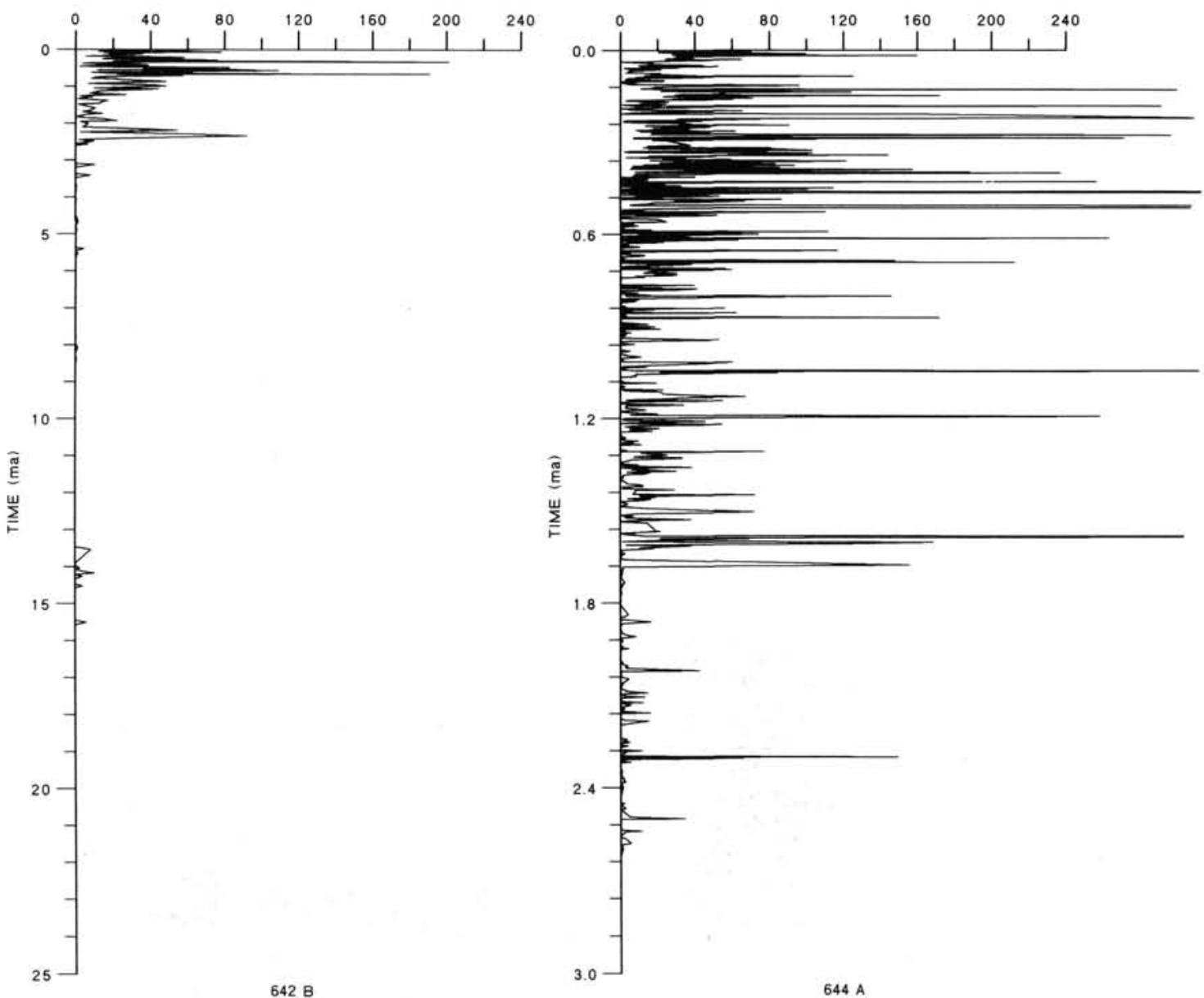

$644 \mathrm{~A}$

Figure 20. Correlation of major coarse-fraction sediment component accumulation rates along the Vøring Plateau paleoenvironmental transect since 25 Ma in Holes 643A, 642B, and 644A. (A) Bulk sediment accumulation rates, (B) rock fragments $>0.063 \mathrm{~mm}$, (C) quartz grains $>0.063 \mathrm{~mm}$, (D) biogenic opal, (E) total carbonate, (F) total organic carbon. Sections without signature in the sediment column indicate hiatuses. 
$\Xi$
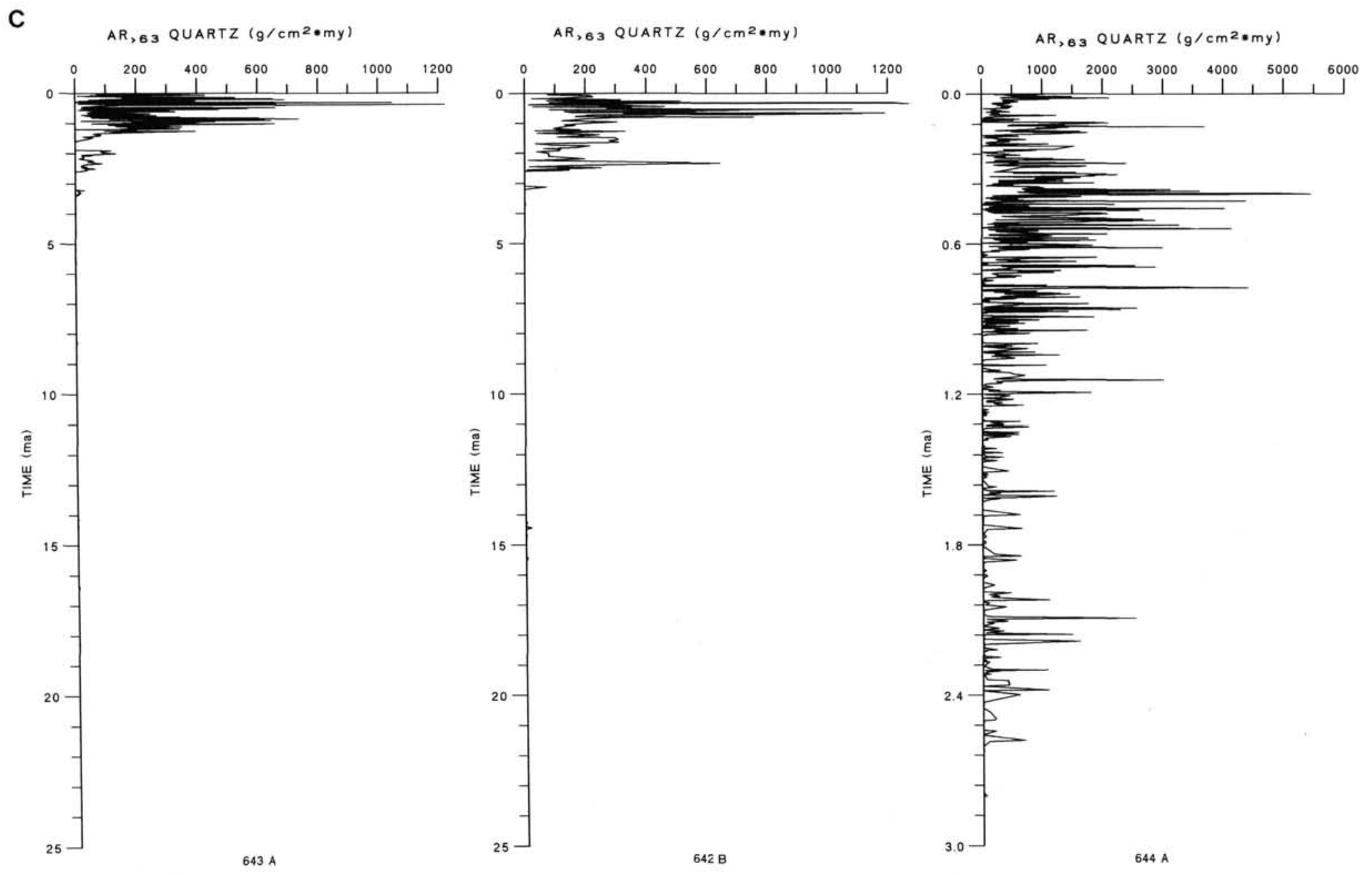

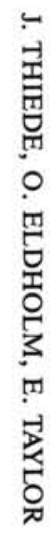


D AR, G3 BIOGENIC OPAL $\left(g / \mathrm{cm}^{2} \cdot \mathrm{my}\right)$

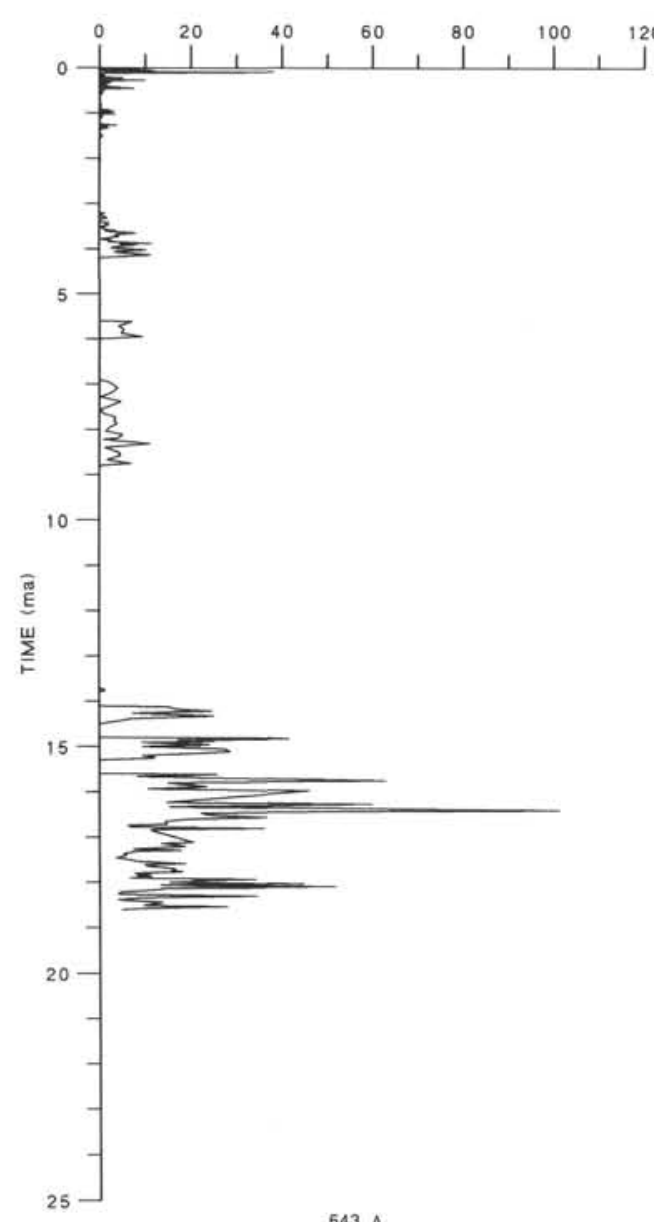

$A R>B, 3$ BIOGENIC OPAL $\left(g / \mathrm{cm}^{2} \cdot \mathrm{my}\right)$

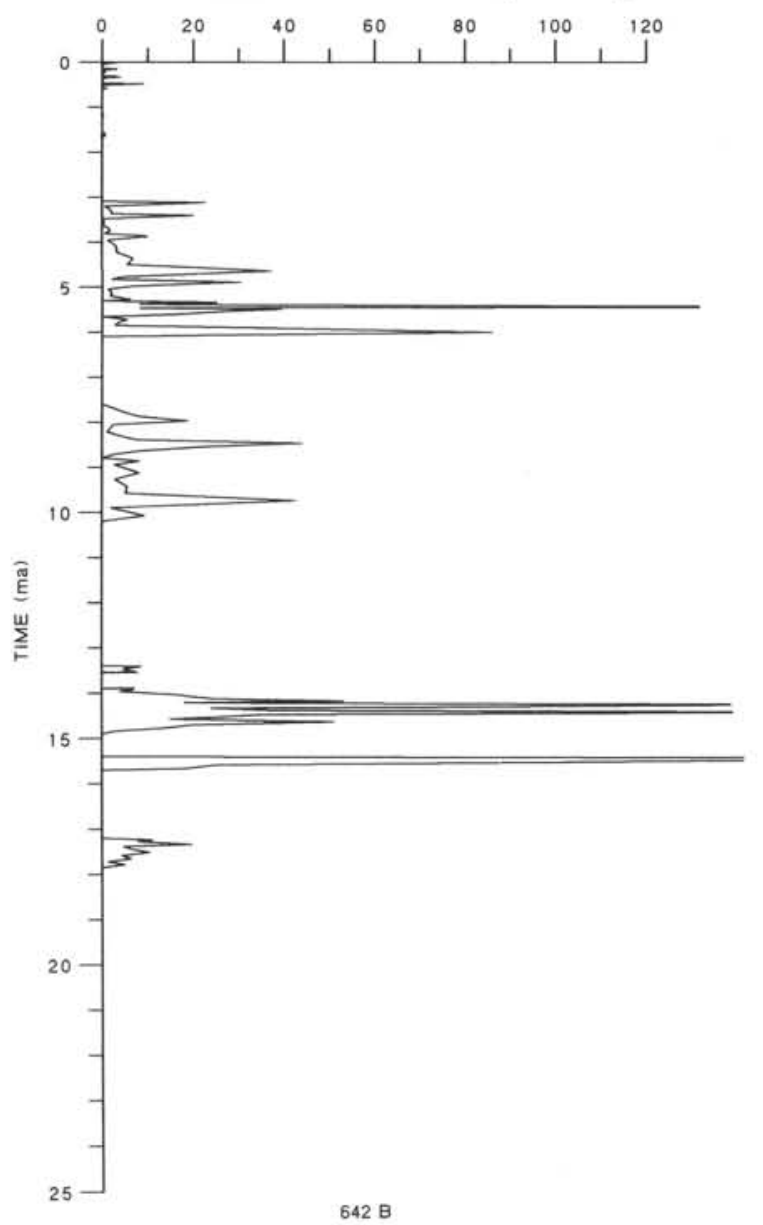

AR, 63 BIOGENIC OPAL $\left(\mathrm{g} / \mathrm{cm}^{2} \bullet \mathrm{my}\right)$

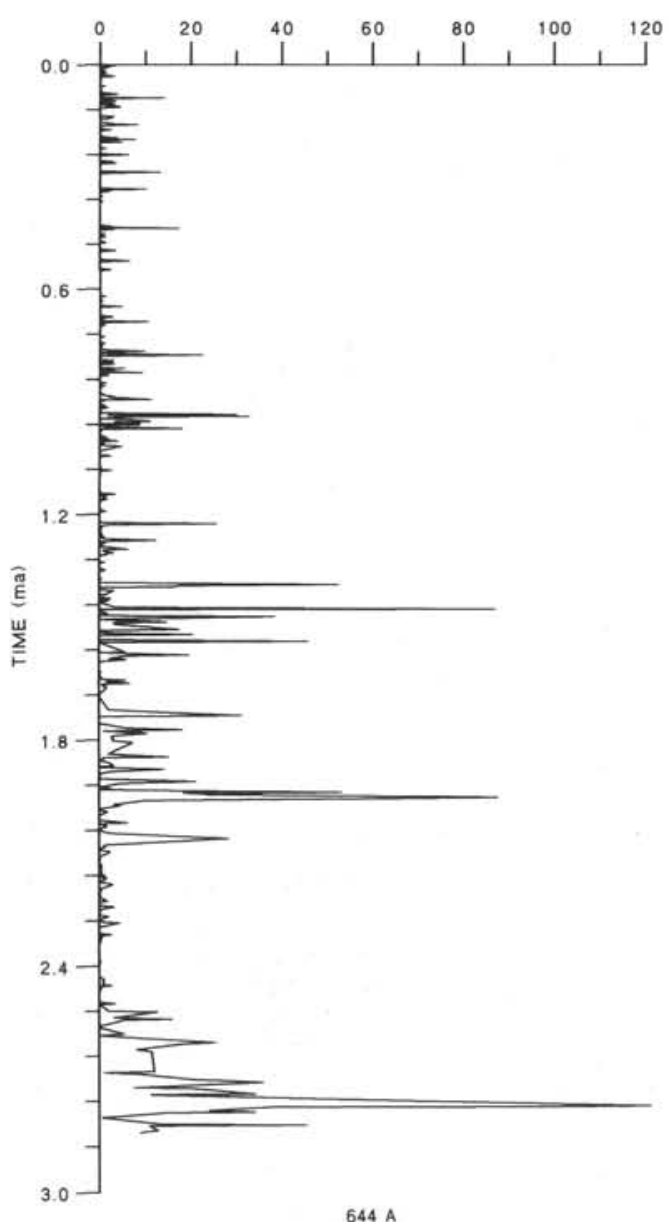

Figure 20 (continued). 
$\bar{\alpha}$
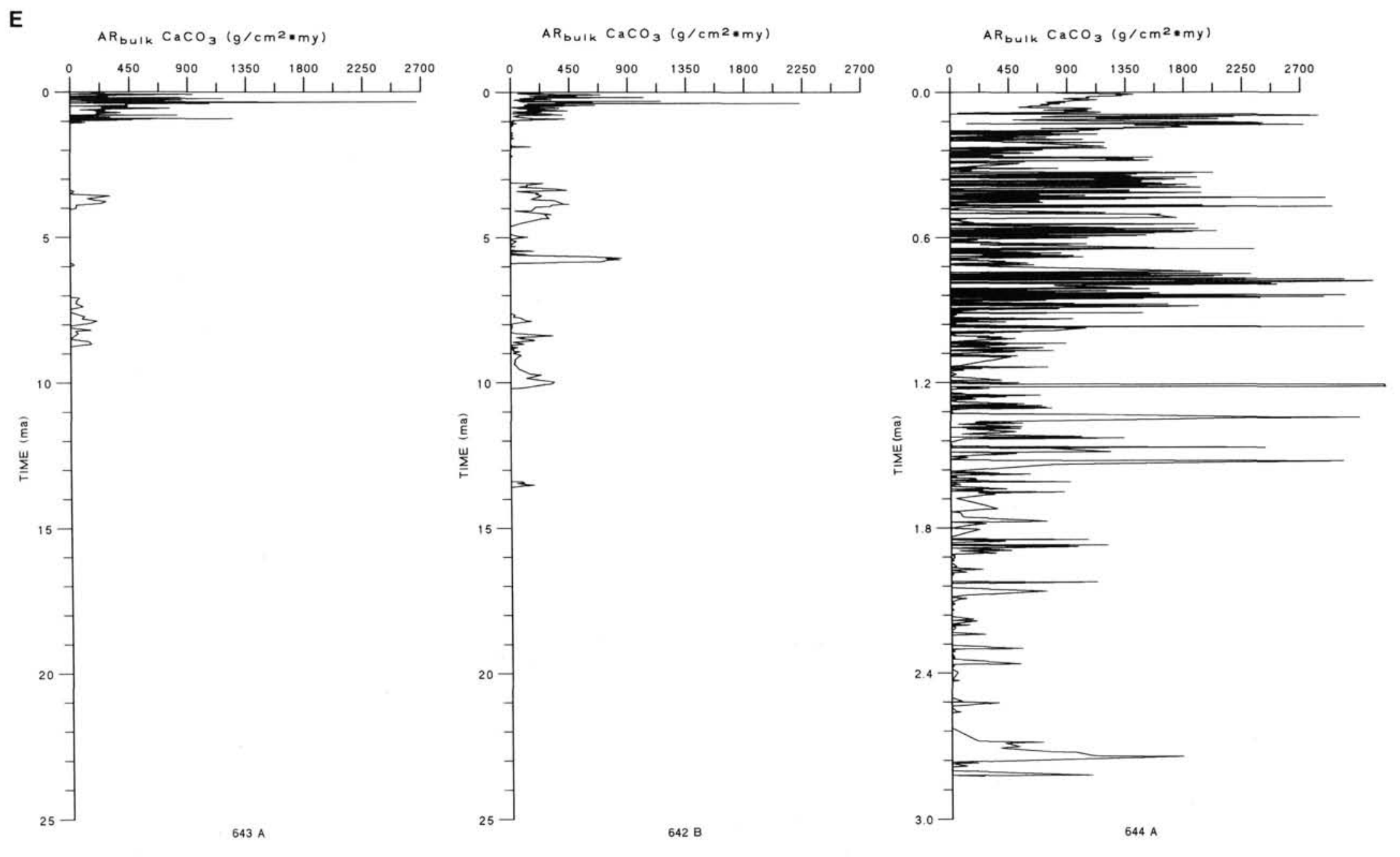
F

$A R_{\text {bulk }} \operatorname{TOC}\left(\mathrm{g} / \mathrm{cm}^{2} \cdot \mathrm{my}\right)$

AR bulk TOC $\left(9 / \mathrm{cm}^{2} * \mathrm{my}\right)$

$A R_{\text {bulk }}$ TOC $\left(g / \mathrm{cm}^{2}\right.$ *my $)$
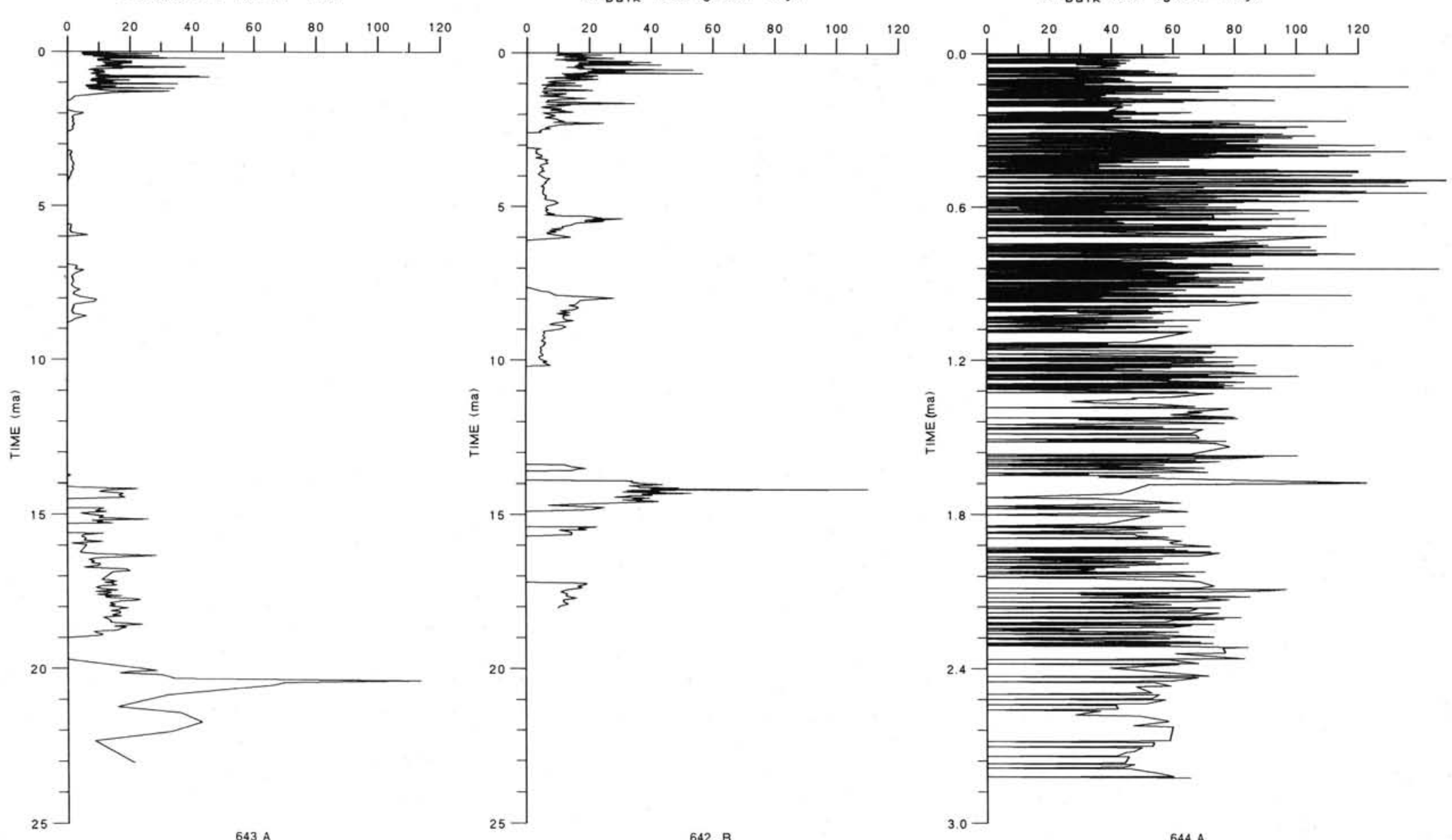

Figure 20 (continued) 
The stratigraphic problems that have plagued the interpretation of the Paleogene sections of the ODP Leg 104 cores are not found in the Neogene and Pleistocene sediments. Instead, these latter sediments can be easily dated and correlated between sites in great detail, as shown by Ramm (1989) as well as Henrich et al. (1989) for the uppermost Quaternary. Properties of the eastern Norwegian Sea surface waters, in particular of the Norwegian Current, can therefore be discussed in terms of an oceanographic transect for Neogene and Quaternary ages. The Leg 104 sites document considerable lateral variation in sedimentation and accumulation rates, composition of pelagic microfossil assemblages, sediments, and in particular the coarse ice-rafted terrigenous clasts in the glacial part of the section. These lateral differences confirm that the site transect idea was successful (Fig. 20).

The gross lithostratigraphic subdivision (Fig. 8) of the Neogene and Quaternary section reflects major long-term changes of the surface-water hydrography of the eastern Norwegian Sea. This record began with the sedimentation of a thick sequence of siliceous, mostly diatomaceous oozes extending stratigraphically from the lower Miocene to the upper Miocene-Pliocene. These sediments were succeeded by intercalated horizons of calcareous biogenic oozes and later by the terrigenous, glacially derived sediments. The extent of these siliceous oozes on a regional scale can be traced using their strange geophysical properties (Hempel, 1989; Hempel et al., this volume). They have also been observed in other North Atlantic drill sites (Bohrmann, 1988). Because of their widespread occurrence it is quite improbable that upwelling regimes have generated the long-lasting, high opal fluxes. Instead they seem to have been linked to the subtropical and temperate climate that controlled surface properties that resulted in high nutrient availability from riverine supply (Henrich et al., this volume). The dominance of the biogenic siliceous sediment components in the Miocene sections of these drill sites suggests relatively high marine productivity as confirmed by accumulation rates of opaline sediment components (Figs. 15, 17, and 20). Rock-Eval analyses (McDonald et al., this volume) have also suggested the presence of a mixture of organic matter of marine and terrestrial origin in the Miocene sediments of Site 642 .

The most detailed information documenting the evolution of the Neogene and Quaternary temperature regime of the surface waters over the Vøring Plateau was produced from studies of silicoflagellates. Locker and Martini (this volume) estimated seasurface temperature conditions based on a formula developed by Kanaya and Koizumi (1966); their results are largely confirmed by Ciesielski et al. (this volume). The T-index used by Locker and Martini (this volume) appears to be more sensitive at the cold end of the spectrum. Their results suggest that the eastern Norwegian Sea was warm (subtropical) prior to 18.7 $\mathrm{Ma}$, but that a phase of poorly resolved cooling events perturbed the system from $18.7 \mathrm{Ma}$ to $16.6 \mathrm{Ma}$. This phase was followed by a warm phase that began to deteriorate at approximately $14.0 \mathrm{Ma}$. This cooling progressed rapidly and most temperate and warm silicoflagellates had disappeared from the eastern Norwegian Sea by approximately 7.4 Ma. Only during, or just before, the Miocene/Pliocene boundary did warmer forms reappear briefly in modest quantities (approx. 5.5-5.4 Ma). Cool to cold waters are indicated for virtually the entire early Pliocene. Large quantities of coarse ice-rafted terrigenous debris (Fig. 16) were shed into the eastern Norwegian Sea, suggesting the firm establishment of glacial environments at $2.6 \mathrm{Ma}$. Most of the siliceous microfossil groups disappeared, or were preserved in small numbers and only sporadically, after establishment of the glacial regime.

The latter part of this paleoenvironmental interpretation has also been confirmed by the dinocyst investigations of Mudie (this volume). During the late Miocene, Pliocene, and into the Pleistocene a progressive decline of species diversity occurs. The lower to middle Miocene cyst assemblages suggest warm, subtropical saline surface water with no input from the Arctic. The subtropical cysts, however, dissappeared prior to $6.5 \mathrm{Ma}$. Close to the Miocene/Pliocene boundary, subarctic Pacific species were able to invade the Norwegian Sea via the Arctic Ocean, possibly marking the onset of the East Greenland Current.

While the pre-glacial environments can only be described by means of pelagic microfossil assemblages, the appearance of preserved calcareous fossils in the Pliocene and Pleistocene sediments allows for detailed isotope studies (Jansen et al., this volume) (Figs. 15 and 17). Oxygen- and carbon-isotope measurements (see also Fig. 19) of benthic foraminifers have now been extended into the uppermost Miocene. Together with the appearance of the first modest quantities of coarse, ice-rafted terrigenous grains (Fig. 16), the isotope data suggest that the arrival of ice in the eastern Norwegian Sea occurred as early as 5.5 $\mathrm{Ma}$ (Jansen et al., in press). The small volume of ice-rafted material and its intermittent occurrence are evidence for periods of an early cold climate that brought ice into the region over the Vøring Plateau where it melted. Early phases of enhanced deposition of ice-rafted coarse material occurred at 5.2-5.0 Ma, 4.74.3 Ma, 4.0-3.7 Ma, and 3.3-3.1 Ma. Benthic foraminifer oxygen isotope ratios became slowly, but consistently heavier during this time span (Table 1).

The most detailed records of the late Pliocene and Quaternary glacial history of the Norwegian Sea have been obtained from measurements of stable light isotope ratios and studies of the coarse sediment fractions. The record of ice-rafted cores and terrigenous debris has produced many interesting patterns of the variability of the glacial history of the Norwegian Sea. From $3 \mathrm{Ma}$ onward to the latest Quaternary the oxygen isotope ratios (Slettemark, 1988; Jansen et al., this volume; Jansen et al., in press) show the general tendency of increasing ranges and variability with decreasing age, but also a trend toward slightly heavier isotope values. While oxygen isotope ratios were close to modern values during the Gauss and the early part of the Matuyama (1.2-1.4 Ma), ratios changed from an early Quaternary minimum (in the late Olduvai) toward a maximum value in the late Matuyama (1-1.2 Ma).

Slettemark (1988) and Jansen et al. (this volume) determined oxygen isotope ratios from shell material of the planktonic foraminifers Neogloboquadrina pachyderma and the benthic foraminifers Cassidulina teretis and Melonis barleeanum. They found evidence of a period between 2.5 and $2.6 \mathrm{Ma}$ to $1.2 \mathrm{Ma}$, when continuous glacial conditions existed without interglacials, such as those we have experienced during the recent geological past. They assume that a different climatic regime resulted in surfacewater circulation distinct from modern day, with little or no deep-water formation, low biological productivity, and very low oxygen isotope ratios in the planktonic foraminifers. This type of surface-water regime, and the lack of deep water formation, led to intensive calcium carbonate dissolution from most of the Matuyama (2.47-0.73 Ma) (Henrich, this volume). Based on similar lines of argument, Jansen et al. (this volume) describe a short influx of intermediate North Atlantic water during 1.65$1.55 \mathrm{Ma}$, but it is only between 1.2 and $0.6 \mathrm{Ma}$ that a transition to the evolution of interglacials occurred, with the first interglacial at approximately 1.0 Ma. From that time forward, calcium carbonate was better preserved except for periods of intensive deglaciations (Henrich, this volume) when large quantities of meltwater contributed significant terrigenous organic material (McDonald et al., this volume). Typical cyclic repetitions of clearly developed glacial and interglacials with a 100-k.y. cyclicity have been described from numerous gravity cores from the Norwegian-Greenland Sea (Henrich et al., 1989; Henrich, this 
volume). This cyclicity is only discernible in the most recent 600 k.y. of the Leg 104 sediments.

As soon as a glacial climate developed over the Norwegian Sea and cold waters were present in the eastern Norwegian Sea, coarse terrigenous ice-rafted material appeared in the sediments, first in small quantities and at irregular intervals (as early as 5.7 Ma). A radical change in the frequencies and abundances of the coarse terrigenous components occurred between 2.4 and 2.8 Ma. From 2.8 to $1.2 \mathrm{Ma}$ coarse terrigenous sedimentation was continuous though small, with only minor fluctuations. After 1.2 Ma the abundance of ice-rafted material increased considerably, as did the range of fluctuations between minimum and maximum input. Ice-rafted detrital input reached maximum at $0.4 \mathrm{Ma}$, decreased to a minimum approximately $0.2 \mathrm{Ma}$, and decreased to a second minimum approximately $0.1 \mathrm{Ma}$. These two minimums enclose a major influx of coarse material. Results suggest that the influx of coarse terrigenous material to the eastern Norwegian Sea was much weaker during the youngest glacial phases than during the latest Matuyama and the earliest Brunhes (approximately 1.0-0.3 Ma) (Fig. 20). These differences suggest that the glacial ice covers during this latter time span were much larger than before or after.

A number of Leg 104 studies have considered the composition of the ice-rafted material (Krissek, this volume; Donnally, this volume; Spiegler, this volume; and Spiegler and Jansen, this volume). This material consists of quartz and rock fragments of questionable origin, of lithic sedimentary and magmatic components, and of reworked Cretaceous and Tertiary microfossils displaced by ice-rafting into Pliocene and Quaternary sediments. Ice-rafted index fossils offer a particularly interesting record of differences between Sites 643, 642, and 644. Site 643 Pliocene and Quaternary sediments contain a mixed assemblage of Tertiary and Cretaceous index fossils. Site 642 also contains mixed Cretaceous and Tertiary index fossils in intervals mostly confined to the Matuyama and most frequently close to the Pliocene/Pleistocene boundary. No ice-rafted fossiliferous material was deposited between 0.5 and $0.3 \mathrm{Ma}$ and since $0.24 \mathrm{Ma}$. The index fossils are particularly enriched in the typical dark sediment layers of glacial origin, deposited during particularly intensive deglaciation processes (Henrich, this volume). The fact that the high-resolution Pliocene and Quaternary stratigraphic record of Site 644 contains only Inoceramus prisms (reworked index fossils of Cretaceous age) indicates that this site was reached by ice of a different regional origin. The ice may have come from nearby shelf regions, but Donnally (this volume) suggests the North Sea was the major source area for the Cretaceous reworked materials. Krissek's (this volume) study of the lithic clasts of the coarse ice-rafted material established a detailed temporal account of its distribution pattern. He points out that correlative horizontal changes suggest different modes of ice drift because Site 644 was reached by ice from a southwesterly direction, whereas Sites 642 and 643 were reached by ice from a northeasterly direction. Thus these studies indicate completely different patterns of ice drift in the eastern Norwegian-Greenland Sea, as would be suggested by the circulation regime of the surface-water masses there.

\section{HISTORY OF NORWEGIAN SEA BOTTOM WATERS}

The history of bottom-water properties and bottom-water circulation is particularly difficult to discuss because the sites have undergone considerable and different amounts of subsidence after the onset of sedimentation. Site 642 was subaerial or very close to the sea surface at $55-58 \mathrm{Ma}$ and then subsided regularly, although somewhat slower than normal oceanic basement, to its present depth. Site 643 basement originated below sea level in approximately $500-800 \mathrm{~m}$ of water depth and then sank following the subsidence curves of normal oceanic crust to its present depth.

Independent of the tectonic reconstructions, Kaminski (1988) provided an estimate of Site 643 subsidence where paleodepth estimates were established by means of arenaceous benthic foraminifer faunas. He concluded that the sediment surface was located close to $550 \mathrm{~m}$ at $55 \mathrm{Ma}$, close to $1140 \mathrm{~m}$ at $52 \mathrm{Ma}$, close to $1960 \mathrm{~m}$ at $37 \mathrm{Ma}$, close to $2270 \mathrm{~m}$ at $28 \mathrm{Ma}$, and close to $2400 \mathrm{~m}$ at $23.5 \mathrm{Ma}$. These rates of subsidence corroborate those established by Skogseid and Eldholm (this volume).

Evidence for reconstructing the history (Figs. 21-23) of Vøring Plateau bottom waters comes from a number of microfossil groups and sedimentological properties, the latter including mechanical sedimentary structures, traces of bioturbation in the cores, and dissolution patterns of calcareous and siliceous material in the sediments. Sedimentary structures, both mechanical and biogenic, have not really been studied in great detail and only occasionally provide quantitative data. Dissolution patterns of the major biogenic sediment components, however, have been studied in considerable detail (Henrich, this volume; Bohrmann, 1988), and important conclusions can be drawn from these data. In addition, oxygen and carbon stable isotope ratios (Fig. 22) have been determined where enough shell material of benthic foraminifers was available (Jansen et al., this volume). Accumulation rates of benthic organisms have also been used to reconstruct bottom-water history (Figs.18 and 20).

\section{Paleogene}

Bottom-water properties recorded in the Paleogene deposits are poor, consisting almost entirely of a few observations from sedimentary structures and sparse but very carefully analyzed data of the benthic arenaceous foraminifer faunas (Kaminski, 1988; Gradstein and Kaminski, in press; Ostermann and Qvale, this volume); in addition, the ecology of these benthic foraminifers is poorly understood. Gradstein and Kaminski (in press) and Ostermann and Qvale (this volume) relate the very problematic ecology of the Paleogene arenaceous benthic foraminifer faunas to a specific deep-water environment referred to as the "old bottom-water model" (Gradstein and Kaminski, in press). They argue-based on various lines of circumstantial evidencethat these faunas are the result of intensive dissolution processes that removed the calcareous faunal components in most of the samples.

The Eocene and Oligocene faunas are in general characterized by a scarcity of specimens and a relatively low diversity. However, enough material has been found to establish a stratigraphy that could be correlated with the Labrador Sea, the western North Atlantic, and especially the North Sea. These correlations suggest that the Vøring Plateau bottom-water environment was not a local event, but was typical for the entire arctic realm including the Labrador Sea and parts of the adjacent shallowwater areas such as the North Sea (Kaminski, 1988). Many of these agglutinated foraminifer assemblages have been called (though probably incorrectly) "flysch" assemblages. Similarities between the North Sea and the Voring Plateau Eocene faunas suggest that a deep-water (probably bathyal, according to Kaminski, 1988) connection between these two regions existed at this time. Examination of the faunas from Leg 38 (Verdenius and van Hinte, 1983) suggested that a harsh, low-nutrient bottom environment existed at that time in the area of the Vøring Plateau. However, this conclusion was contradicted by Berggren and Schnitker (1983) based on the evidence for biological blooms in the surface-water masses, which also suggested an important flux of nutrients to the seafloor.

It is clear that erosive processes interrupted the completeness of the sedimentary sequences of the Vøring Plateau in particular, but also of the entire Norwegian-Greenland Sea (Goll, this 


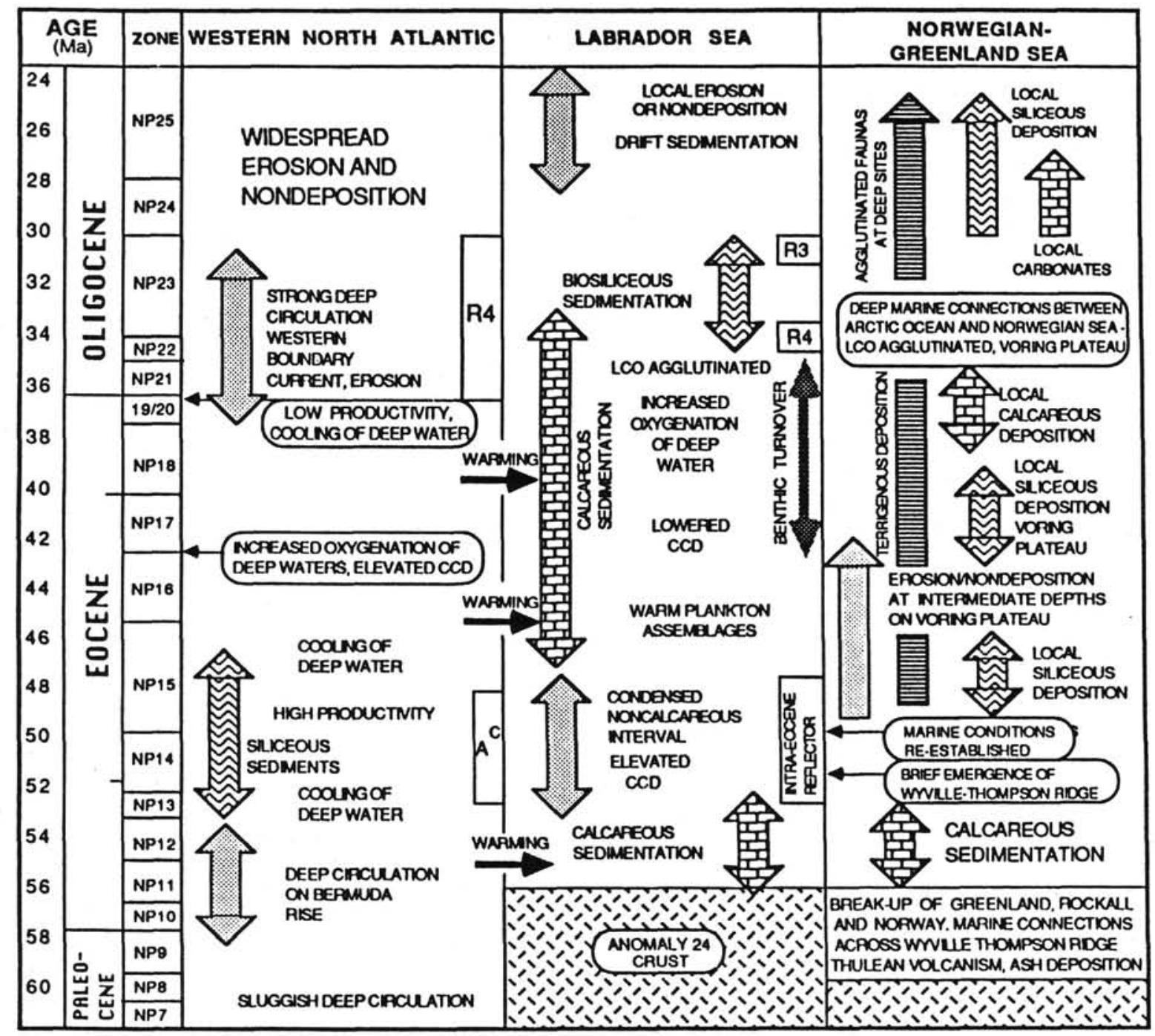

Figure 21. Synthesis of Paleogene depositional environments, paleoceanography, and important faunal events in the high-latitude North Atlantic, from Kaminski (1988).

volume). The numerous hiatuses imply repeated pulses of intensive bottom-water renewal leading to the erosion of the soft and organic-rich sediment cover. The source of these bottom waters and how the resulting hiatuses correlate in detail with the global hiatus record (Keller et al., 1987) is still unclear. Other questions concern whether the assumption of the oxygen deficiency based on sedimentary structures and composition is reasonable, and what kind of process might have driven the bottom-water circulation at that time. A relatively high Greenland-Scotland Ridge probably inhibited an intensive deep-water exchange between the main North Atlantic Basin and the Norwegian-Greenland Sea. Some of these hiatuses seem to extend to adjacent shelf area (Goll, this volume) where Cenozoic sections have been drilled on Haltenbanken (Dalland et al., 1988).

The most convincing paleoenvironmental interpretation of the Paleogene arenaceous benthic foraminifers comes from Site 643 (Kaminski, 1988). It largely concurs with the conclusions of Ostermann and Qvale (this volume). He compared the faunas from the Norwegian-Greenland Sea with those from the Labrador Sea and the western North Atlantic and found a considerable amount of similarity between these faunas (Fig. 21). As in Osterman and Qvale (this volume), he indicated that the evolution of Paleogene Norwegian-Greenland Sea bottom waters can be subdivided into a number of steps that influenced the composition of these benthic faunas. These steps are markedly related to the subsidence of the Greenland-Scotland Ridge (Thiede and Eldholm, 1983) and the continued subsidence and change of the Vøring Plateau bottom-water depositional environments.

\section{Neogene Pre-Glacial Bottom-water Paleoenvironments}

The Miocene and lower Pliocene sedimentary sequences of Sites 643 and 642 are characterized by a complete change in sediment composition from almost non-fossiliferous mud (stone) to biogenic siliceous and calcareous oozes. The amount of siliceous material in the Site 642 sediments is much smaller than at Site 643. This difference reflects a more pelagic environment at the latter (Fig. 11). As outlined in other studies (Henrich et al., this volume), this change in the sediment composition coincides with a major revolution of the benthic fossil assemblages.

Poorly preserved, benthic ostracode assemblages from the Leg 104 sites indicate purely marine depositional environments (Malz, this volume). The faunas studied consist of species with relatively broad paleobathymetric ranges, and in which the Miocene faunas are the poorest in comparison to the Pliocene and the Pleistocene assemblages. Only 13 specimens belonging to five different species have been found in the Miocene and lower- 

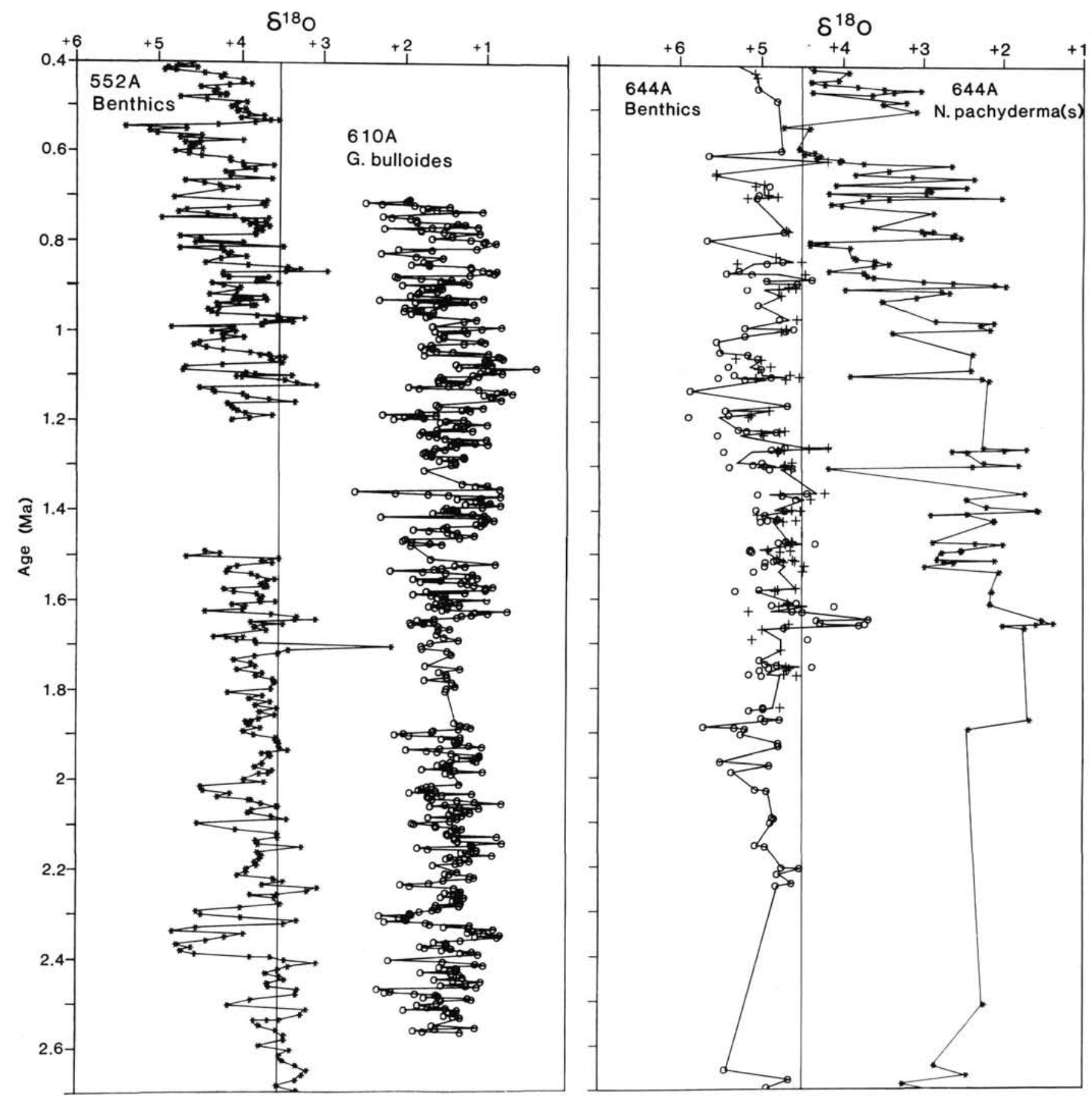

Figure 22. Benthic oxygen isotope record and coarse-fraction proportion of sediments from Hole 644A (from Jansen and others, this volume).

most Pliocene deposits. These specimens generally consist of juvenile specimens that have their optimal ecologic range in somewhat shallower water. The specimens found do not have any signs of downslope transport, but they do not represent deepsea genera either. Ostracodes, however, are not easily interpreted in terms of paleoenvironmental conditions. Poor preservation of the ostracode faunas has been attributed to a lack of deep-water exchange, inhibited by the barrier of the Greenland-Scotland Ridge, as well as the oxygen-deficient waters. These conditions developed during the Miocene in the Norwegian-Greenland Sea and led to the deposition of the organic carbon-rich diatomaceous sediments over a long time span. The conclusion from the ostracode faunas is that the Norwegian-Greenland Sea was simply a non-ostracodal habitat Malz (this volume).

Benthic foraminifers (Fig. 18) provide evidence of the changing bottom-water depositional environments. Calcareous faunas appeared first in Miocene sediments as a minor component in combination with the arenaceous faunas. The data suggest that an extreme dissolution event occurred during the early and middle Miocene, destroying most of the calcareous benthic foraminifers. Due to the meager benthic foraminifer faunas in the earlier part of the Miocene, it is uncertain when the Norwegian Sea became a source region for the bottom-water renewal. However, modern benthic foraminifers (Zone B of Ostermann and 


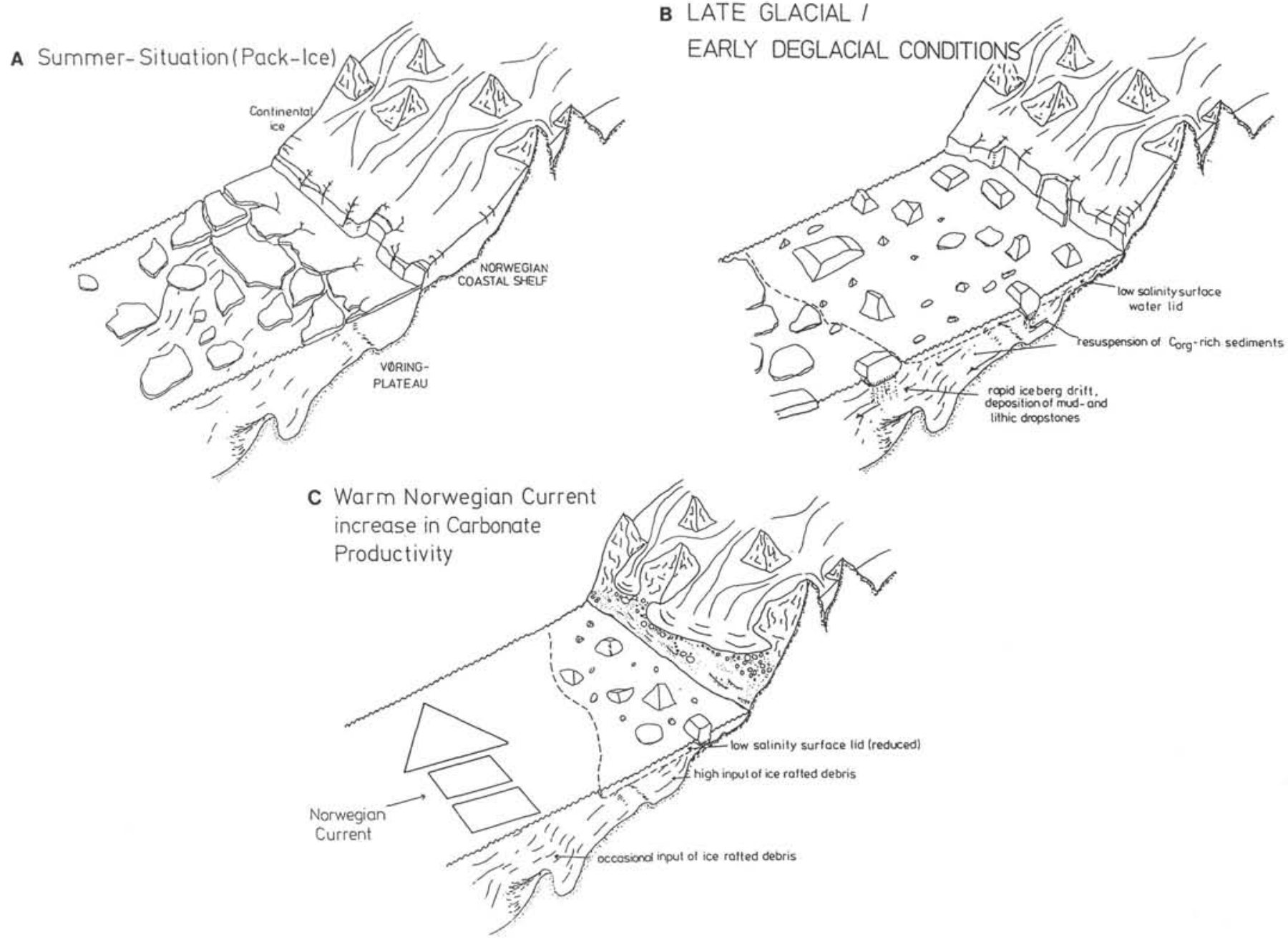

Figure 23. Paleoenvironmental model. (a) Strong glaciation reflecting advance of continental ice on the Norwegian coastal shelf associated with offshore pack ice drift. (b) Late glacial/early deglacial strong iceberg drift induced by surges of the marine-based parts of continental ice. (c) Intrusion of the Norwegian Current with retreat of iceberg drift progressively closer to the coastal regions and offshore increase in carbonate productivity (reproduced from Henrich et al., in press).

Qvale, this volume) became established during the middle Miocene, indicating that an oceanic circulation regime comparable to the modern Norwegian-Greenland Sea oceanography had evolved prior to that time.

Although the homogeneous nature of the Miocene and lowermost Pliocene sedimentary sequences appears to reflect a generally very quiet and unchanged depositional environment, the frequent variations of benthic organisms, such as sponge spicules (Henrich et al., this volume), suggest otherwise. The assemblage, together with the occurrence of scarce ostracodes and benthic foraminifers (Fig. 14), support the idea that the bottom waters were oxygenated. However, based on the amount of organic carbon present in later sediments, Miocene-Pliocene bottom waters were probably only slightly oxic. The intensive degree of carbonate dissolution in the sediments suggests that remineralization processes were of high intensity during these Miocene and earliest Pliocene intervals. The temperature and salinity histories of the Neogene bottom waters are unknown.

The continuity of the Neogene sedimentary sequences of both Site 642 on the central Vøring Plateau and Site 643 on the foot of the Vøring Plateau has been interrupted by numerous, in part regionally clearly correlatable, hiatuses. Goll (this volume) defined seven clearly identifiable hiatuses, five of which can be found both in Sites 642 and 643 . Two others are believed to be of regional scope and diachronous nature. Despite the diachroneity of many small and large unconformities at these sites, the degree of Neogene erosional truncation is remarkably similar. The Neogene sedimentary record at Site 643 prior to $13.7 \mathrm{Ma}$ is interpreted to be more than $80 \%$ complete as compared to $46 \%$ at Site 642 for the Neogene sediments older than 13.4 Ma. An opposite relationship holds for the sediment above the middle Miocene unconformity where the sedimentary record is more than $80 \%$ complete since $10.2 \mathrm{Ma}$ at Site 642 and only $64 \%$ complete since $8.8 \mathrm{Ma}$ at Site 643 . Goll (this volume) has also attempted to correlate these hiatuses with the cycle stratigraphy and sea-level curve of Haq et al. (1987), although the correlations are not always completely convincing.

The Neogene sedimentary record of Sites 642 and 643 can be described as a series of unconformably bounded sequences. There seems to be a good match between the Neogene hiatuses of the Norwegian-Greenland Sea (Goll, this volume) and Neogene hiatuses of the Pacific Ocean as defined by Keller and Barron (1987); some of them might even extend into the Indian and Atlantic oceans. It is an open question how the deep-water erosion of the Pacific Ocean and of the relatively isolated Norwegian-Greenland Sea can have such a large degree of similarity. 
This problem will only be solved after a major synthesis of all available ODP and DSDP data from the concerned regions.

There is a considerable amount of contradictory evidence based on information obtained from microfossil assemblages and hiatuses as evidence for erosional activity on the Vøring Plateau seafloor. Ostracode data, benthic foraminifer data, and the sedimentary structures of the Miocene and lowermost Pliocene sections suggest a rather quiet depositional environment. The occurrences of the hiatuses, however, in the NorwegianGreenland Sea as well as in the North Atlantic Ocean (Ehrmann and Thiede, 1985) are evidence for major evolution of the bottom-water circulation. How these contradictions can be reconciled remains to be solved.

\section{Late Neogene and Quaternary-Glacial Seafloor Paleoenvironments}

There is a multitude of data available to address the late $\mathrm{Ne}$ ogene and Quaternary deep- and bottom-water paleoenvironment. As for the older intervals there is direct microfossil evidence from ostracodes, benthic calcareous foraminifers (Fig. 14), and sponge spicules (Fig. 18). There are numerous observations derived from the character and distribution of mechanical and biogenic sedimentary structures and from sedimentation rates. Because a major portion of this part of the sedimentary sequence contains calcareous microfossils, detailed records of the stable oxygen and carbon isotopes in benthic organisms (Fig. 22) and dissolution patterns of calcareous, mainly planktonic, foraminifers (compare Henrich, this volume) have been made.

The uppermost Pliocene-Pleistocene sediments contain increasingly more ostracodes (Malz, this volume). Whereas the Pliocene samples only contain a total of 15 specimens belonging to four, maybe five species, the set of Pleistocene sediments contains 91 specimens belonging to 22 species that show close relationships to the boreal and arctic faunas. Most of these species-as known from the Holocene-usually live in water depths of less than $200 \mathrm{~m}$, which may explain the occurrence of mostly juvenile forms. As for the older time spans, however, the ostracodes are not very conclusive for the bottom-water paleoenvironment under a glacial ice cover.

The benthic foraminifer faunas of the Pliocene-Pleistocene intervals are characterized by an increasing diversity of calcareous faunas. They occur in many sediment samples although the upper Pliocene and Pleistocene sections also include many virtually barren intervals where only ice-rafted shallow-water specimens such as Elphidium excavatum are found together with a large amount of ice-rafted material. It is only during the interglacial time spans that rormal oceanic deep-water faunas have evolved in the Norwegian-Greenland Sea. A wide sample spacing has inhibited a very detailed description of the benthic foraminifer faunas in response to the glacial/interglacial fluctuations. There are also considerable differences in the composition of the benthic foraminifer faunas of Sites 643 and 642 relative to those from 644 . The latter site is located only $440 \mathrm{~km}$ from the Norwegian coast, and its glacial sequences contain numerous shallow-water foraminifers documenting the close proximity of the coastal area and of the continental shelf.

Some of the most important evidence for the late Neogene and Quaternary bottom-water paleoenvironments comes from the measurements of stable oxygen and carbon isotopes (Jansen et al., this volume). Sediments containing isolated carbonaterich horizons first occur in the uppermost Miocene, are increasingly present in the Pliocene, and are found continuously throughout the uppermost part of the Quaternary. Isotope ratios from benthic foraminifer shell material found in these horizons clearly document individual, isolated, glacial events close to $5 \mathrm{Ma}$ (Jansen et al., in press). Isotope values indicate intergla- cial values in the time span between 4.7 and 4.2 Ma. It was only later, near $2.7 \mathrm{Ma}$, that the benthic oxygen isotope ratios (Jansen et al., this volume) reached truly glacial values (Fig. 22). With a few interruptions of warmer intervals, a high-frequency variability can be observed in these data for the past $2.7 \mathrm{Ma}$. Increasingly heavier oxygen isotope ratios occurred almost throughout the entire time span until a maximum was reached between 0.4 and $0.1 \mathrm{Ma}$. The high-frequency variability and the trend toward increasingly colder environments was interrupted by few levels indicating lighter isotope values, for example between 1.6 and $1.7 \mathrm{Ma}, 0.8$ and $1 \mathrm{Ma}$, and isolated individual samples in between. Since $100-150 \mathrm{Ka}$ the isotope values decreased again, but the data from Site 643 do suggest that the regular sequence of glacial/interglacial isotope stages from stage 1 back to stage 21 at approximately $0.8 \mathrm{Ma}$ can be defined.

Henrich (this volume) found an inverse correlation between calcium carbonate and organic carbon for these sediments. He also described an overall trend of decreasing organic material from 1 to $0.1 \mathrm{Ma}$ (Fig. 20). Calcareous shell material is increasingly preserved over this same interval, as exemplified by the dissolution index of Neogloboquadrina pachyderma. N. pachyderma is almost completely destroyed and dissolved in the sediments older than $1 \mathrm{Ma}$, but shows a general trend of better preservation with decreasing age. There seems to be a very clear inverse relationship between the input of organic material, that is known (McDonald et al., this volume) to consist of dominantly terrigenous ice-rafted detritus, and the preservation of the calcareous shell material (Fig. 23). The organic-rich intervals coincide with very easily identifiable dark, almost black, sediment horizons with virtually no bioturbation, which seems to suggest a very sluggish or non-existent bottom-water renewal for very short time intervals. These intervals probably occurred either close to the transition from glacial to interglacial stage or within a glacial interval characterized by strong ice advance, possibly close to the shelf edge (Fig. 23) (Henrich et al., 1989).

Sedimentation hiatuses seem to have occurred less frequently during the late Neogene and Quaternary, and with decreasing frequency in shallower water depths. Goll (this volume) described at least three hiatuses in sediments younger than $5 \mathrm{Ma}$ at Site 643 . At Site 642 only one clearly identifiable hiatus has been noted. Site 644 seems to be stratigraphically complete back to approximately $3 \mathrm{Ma}$. If Goll's interpretation is correct, it would mean that bottom-water activity (maybe as well as slumping) was more intense along the foot than on top of the Vøring Plateau. This observation correlates well with the mode of deep-water renewal over this entire time span. Some sediments within the upper Neogene to Quaternary are also enriched with displaced fossil material (Spiegler, this volume), but we assume that most of this material is ice-rafted, rather than mechanically displaced by bottom-water currents as outlined by the author.

\section{HISTORY OF NORTHERN HEMISPHERE PALEOCLIMATES}

Direct evidence of paleoclimatic significance has been obtained from the studies of palynomorphs, in particular pollen and spores, by Boulter and Manum, Manum et al., and Mudie (all this volume). The compositional and temporal patterns of ice-rafted coarse terrigenous debris that reached the Vøring Plateau during the past 5.7 m.y. (Jansen et al., in press; Krissek, Henrich et al., Henrich, all this volume) carry information on presence and dynamics of the ice shields that developed in the course of Cenozoic Northern Hemisphere cooling over Scandinavia and other land and shelf areas adjacent to the Norwegian-Greenland Sea. Clay mineralogical studies of ODP Leg 104 sediments also provide for ample evidence of Cenozoic paleoclimate over the source regions of the detrital material car- 
ried into the ocean (Froget et al., this volume). Indirect paleoclimatic evidence can be drawn from the numerous pelagic fossil groups that have been found mainly in the Neogene and Quaternary sediments of ODP Leg 104 Sites and DSDP Leg 38 drill sites. Although the climatic implications of these fossil occurrences are easily recognized and quantified for the Quaternary and latest Neogene (CLIMAP, 1976), this information turns out to be ambiguous and in part contradictory in the earlier sediments.

Many of the attempts to reconstruct Northern Hemisphere Cenozoic paleoclimate rely on correlations of dated marine and continental sedimentary sequences. Stratigraphic problems have haunted these attempts because of the scarcity of suitable dating techniques that can be applied both to pelagic and continental sequences. Even the correlation of marine events and glaciations on the northeast Atlantic margin during the Quaternary (Bowen and Sykes, 1988) is still a subject of intense debate. Particularly important discrepancies to ODP Leg 104 findings have been pointed out in the circum-arctic realm (Thiede et al., 1988). Paleogene evidence from Svalbard (Dalland, 1977), Neogene data from northeastern Greenland (Funder et al., 1985), northern Alaska (Carter et al., 1986) and upper Neogene-Quaternary evidence from the base of the Greenland ice shield (Harwood, 1986) do not fit the interpretations of the corresponding pelagic record. Many of these discrepancies are probably due to stratigraphic problems that will be solved in time, but the virtual lack of a detailed set of data from the central Arctic Ocean represents probably the most important obstacle to further progress in understanding the processes that led to the Cenozoic cooling events in the Northern Hemisphere. Because of the quality of the ODP Leg 104 data, from sites located in what is probably the most climatically sensitive region of the world ocean, we are presently favoring these results as opposed to the evidence from the incoherent and stratigraphically short shelf and land sections.

The earliest climatic evidence from the Vøring Plateau has been obtained from palynomorph studies of intrabasaltic sediment layers of the lower volcanic series at Site 642. A vegetation consisting of conifer forests (Boulter and Manum, this volume) with some ferns and deciduous arborescent angiosperms has been established based on pollen and spores. Biogeographically they belong to the upper Paleocene/lower Eocene floras of the Brito-Arctic Igneous Province. According to Krutzsch (1966) this flora developed during a short cool climatic period possibly correlative with a cooling event described by Shackleton (1986), close to the Paleocene/Eocene boundary. These floras probably originated from the central Arctic (Boulter and Manum, this volume), and were bound to volcanic soils in conjunction with the extensive volcanism of that time. The environment consisted of a mixed woodland-type landscape whose lower slopes were covered by swamps containing cypress-like trees with ferns. Fungal spores were associated with rotting vegetation. The climatic inferences of this interpretation agree reasonably well with the clay mineral data that imply weathering conditions under a hot and moist climate leading to the formation of lateritic soils (Nilsen and Kerr, 1978).

The Eocene to modern Northern Hemisphere paleoclimates can only be described in relatively general terms. The most important paleoclimatic information for the later part of the $\mathrm{Pa}$ leogene, for the Neogene, and in part for the Quaternary are derived from the detailed mineralogic analysis of the ODP Leg 104 sediment sequences. Froget et al. (this volume) studied the bulk mineralogy and geochemistry of the clay fraction to determine the source of detrital components of sediments, the type of climates prevailing in the source region and, where possible, the oceanic current regimes.
Based on the presence of chlorite and quartz, Froget et al. (this volume) suggest that continued warm but somewhat less moist conditions than during the earlier part of the Paleogene existed from Eocene to Oligocene. At the beginning of the early Miocene, climatic conditions were still warm and damp. The abundance of silica and the virtual absence of fine detrital material in the sediments were probably caused by a vegetation cover in the sediment source area that was sufficiently thick to trap even fine-grained particles. During the middle/early Miocene a mineral assemblage similar to the previous one continued to be transported to the depositional site. However, quartz and feldspar have been observed in the coarse fraction and chlorite and kaolinite in the clay fraction; this suggests the continuation of a warm to temperate climate, but with fewer effects of hydrolysis. From the latest early Miocene and through the middle to late Miocene, clay assemblages indicate a progressive cooling from relatively warm to temperate conditions, with no intense continental erosion. From the latest Miocene through the Pliocene and Pleistocene, the variable mineralogy of the deposits reflects the alternating glacial/interglacial climatic episodes. The mineralogy comprises various clay minerals, quartz, feldspars, and amphiboles, and was influenced by the presence of ice-rafted material, possibly in part produced by the erosion of coastal moraines. Site 644 sediments indicate that a much colder and drier climate existed during or prior to the early Brunhes, or earlier, than in younger sediments.

Pollen and spore concentrations show cyclical variations that appear to correspond to the climatic variations in the Pliocene and Quaternary (Mudie, this volume). In the older sediments these variations are interpreted to be the result of climatic changes influencing plankton productivity. According to Mudie (this volume), the disappearance of a number of middle Miocene dinocyst species at $6.5 \mathrm{Ma}$ suggests early stages of high-latitude climatic cooling. It is only in the Pliocene, however, that 12 cyst taxa disappeared, which is interpreted to reflect the onset of major continental glaciation.

The Norwegian-Greenland Sea has a profound influence on the climate of the Arctic. The paleoclimatic evidence collected from the ODP Leg 104 drill sites in the eastern Norwegian Sea has contributed a new and very important set of data covering the Cenozoic climatic change. These data are important for evaluation of the present climate of the Arctic Ocean itself and its possible past and future states as discussed in detail by Barry (in press). The eastern Norwegian-Greenland Sea and the advection of heat to the subpolar-polar region through the Norwegian Current are some of the most sensitive elements of this system which, according to model calculation, has been cold for a long time. Donn and Shaw (1972) suggested that the arctic regions were cold even during times when the Arctic Ocean was ice-free, with centers of depressed temperatures over the Canadian Arctic Islands, northern North America, and the region of the northernmost part of Siberia and northeastern Europe. The Arctic Ocean temperatures, however, vary from near $0^{\circ} \mathrm{C}$ during winter to a few degrees above $0^{\circ} \mathrm{C}$ during summer. The recent variability of this region is very high, as shown by Lamb (1972) (see also Fig. 2 in Eldholm, Thiede, and Taylor, this volume) and it is likely that it would not take much of a climatic change to switch the present interglacial mode of the Northern Hemisphere climate to glacial. Such a change would alter the entire polar energy budget, the patterns of atmospheric circulation over the Northern Hemisphere, and the sea-ice regime in the Arctic Ocean and the northern Greenland Sea. Even though the ODP Leg 104 drill sites are located in a region that is poorly suited to determine the early onset of glaciations, these sites can be used with confidence to monitor the short-term variability of the glacial/interglacial system and of the cold intervals during 
the transition between the pre-glacial and the glacial Northern Hemisphere climate.

\section{QUESTIONS FOR FUTURE DEEP-SEA DRILLING}

The exciting results of ODP Leg 104 concerning the paleoenvironment of the Norwegian-Greenland Sea and the Cenozoic paleoclimate of the Northern Hemisphere open important perspectives for future deep-sea drilling activities in the area north of the Greenland-Scotland Ridge. It is hoped that the main structural features of the central Arctic Ocean such as the Alpha-Mendeleyev Ridge, the Makarov Basin, and the Lomonosov Ridge will be drilled before the turn of the century to obtain long and undisturbed sequences of the sedimentary cover and samples of the basement. Meanwhile, drilling operations can be continued by means of the available techniques. Exciting problems of paleoceanographic history and plate tectonic evolution of the Norwegian-Greenland Sea/Arctic Ocean complex can be solved by coring at a number of localities. Below we list a number of scientifically valuable potential coring localities, described from north to south without assigned priorities.

1. Yermak Plateau: The Yermak Plateau, to the north of Svalbard, is seasonally ice-free in the area where it abuts the continental margin. It is covered by thick undisturbed Quaternary and (?) Neogene sedimentary sequences that would offer information on the paleoceanography of the middle and late Cenozoic Arctic Ocean.

2. Central Fram Strait: Plateau between the Molloy Deep and the Hovgaard Fracture Zone in the central Fram Strait. The undisturbed sedimentary sequences of this plateau will offer information on the transition from pre-glacial to glacial conditions and on the water exchange between the deep Arctic Ocean and the Greenland Basin.

3. Western central Greenland Basin: An undisturbed sedimentary sequence is resting on top of relatively old Paleogene oceanic crust, but modern intraplate volcanism (Vesterisbanken) has disturbed the regular evolution of the oceanic crust. It will be possible in this region to sample a relatively old stratigraphic sequence and to try to evaluate the impact of the important downwelling processes and the intensive bottom-water renewal.

4. The extension of the paleoenvironmental transect from the Vøring Plateau along the Jan Mayen fracture zone to the East Greenland continental margin: This transect will probe sedimentary sequences documenting the history of the central Norwegian-Greenland Sea water mass that is under dominant polar influence, and its western extension, in particular the history of the East Greenland Current. The East Greenland Current should have a much longer glacial history than the region of the Vøring Plateau.

5. The continental margin of East Greenland just outside Scoresby Sund is characterized by very important sediment accumulation, linked in its origin to the history of this fjord system and to the Greenland ice shield in the continental hinterland.

6. The Aegir Ridge and the easternmost Iceland Plateau is located in a region of important Paleogene perturbations of the plate tectonic framework of the opening of the NorwegianGreenland Sea. In addition to studies of the nature and age of the oceanic crust, it would be very important to sample the older part of the stratigraphic sections.

7. The history and origin of the Greenland-Scotland Ridge is not well understood even though this volcanic ridge is one of the most important aseismic rises of the entire earth. Its construction and subsidence had far-reaching consequences for the paleoceanography of the Norwegian-Greenland Sea, the North Atlantic Ocean, and the paleoclimate of the entire Northern Hemisphere.
The investigations of ODP Leg 104 samples and data and their evaluation will go on for many years to come, because they provide a unique set of information on the early history of the young Norwegian Sea and of the Neogene and Quaternary paleoenvironment. However, for a complete understanding of the problems addressed during Leg 104, the other locations listed here must be sampled. It will be an important effort to complete this history of the Norwegian-Greenland Sea Arctic Ocean paleoenvironment, which holds the key to one of the most exciting processes of Earth history.

\section{CONCLUSIONS}

1. The ODP Leg 104 drill sites penetrated Quaternary, Neogene, and Paleogene pelagic and hemipelagic deposits. At Sites 642 and 643 the sediments overlie volcanic basement. The latter consists of oceanic crust at Site 643 (foot region of the Vøring Plateau) and of a theoleiitic volcanic sequence of "dipping reflectors" on top of older volcanic rocks of dacitic composition with continental affinities at Site 642. Numerous interlayered fossiliferous sediment horizons in the "dipping reflectors" document a dominantly subaerial, episodic volcanic activity with lateritic soils forming on top the flows. The oceanic crust of the outermost Vøring Plateau formed in intermediate water depths. The central part of the Vøring Plateau rose originally above sea level; the highest volcanic peaks subsided below sea level in the Neogene. The differential subsidence of this segment of the volcanic margin of central Norway resulted in considerable difficulties in interpreting bottom-water properties because of the continuously changing depth levels.

2. Evidence of the Paleogene surface-water properties obtained from the intravolcanic sediment horizons of Site 642 and the Paleogene part of the sedimentary sequence of Site 643 is difficult to interpret because the Vøring Plateau subsided rapidly during that time and its central part was obviously located close to a former shoreline whereas the water masses just outside were clearly influenced by pelagic depositional environments. The scarcity of dinocysts, diatoms, radiolarians, ebridians, and silicoflagellates documents the early transgression of the sea into the narrow and young basins of the NorwegianGreenland Sea.

3. Evidence for the Paleogene bottom-water properties of the eastern Norwegian Sea is poor, a result of the few observations of sedimentary structures and scarce benthic arenaceous foraminifers. The poorly preserved and scarce faunas may be the result of intensive dissolution processes that removed the calcareous faunal components. Eocene and Oligocene faunas are in general characterized by a scarcity of specimens and relatively low diversity. During the Miocene the sediment composition changed completely; biogenic siliceous oozes dominate the lithologies of Sites 642 and 643, reflecting a relatively high surface-water productivity and deep-water mas that are poorly ventilated and that caused intensive dissolutic 1 of calcium carbonate. However, the benthic foraminifers provide rich evidence of changing bottom-water depositional environments, although the information is too meager at present to determine when the Norwegian Sea became a source region for the bottom-water renewal of the main North Atlantic Basin. Benthic foraminifers seem to suggest that water exchange between the main North Atlantic basin and the Norwegian-Greenland Sea, resembling the modern circulation regime, became established in the middle Miocene. In general, the Miocene and lowermost Pliocene sedimentary sequences give the appearance of a quiet and slowly changing depositional environment, but frequent variations of most benthic organisms suggest highly variable living conditions on the seafloor of the Vøring Plateau.

4. The drill sites form a paleoenvironmental transect across the Plateau from the Vøring Basin to the foot region of the Vøring Plateau. The transect crosses the central part of the mod- 
ern Norwegian Current, which is one of the most sensitive elements of the modern climatic regime, and whose temperate to cool water masses were replaced by cold, mostly ice-covered waters during glacials (Fig. 23). While information on Paleogene depositional environments was only obtained from Sites 642 and 643, Neogene and Quaternary deposits were collected at all three sites. Differences in sediment composition and flux rates have been used to establish gradients between different segments of the Norwegian Current and the various bottom waters that abutted the continental margin.

5. The paleoenvironmental theme dominating many ODP Leg 104 studies is the transition from a temperate early Neogene to the glacial Pliocene, in particular Quaternary surface waters, which drastically affected and changed the properties of the eastern Norwegian Sea (Table 1). Although the ODP Leg 104 drill sites are located in a region poorly suited to determine the initial onset of glaciations, these sites can be reliably used to document the short-term variability of the glacial/interglacial system and to study the cold intervals that existed during the transition between the pre-glacial and the glacial Northern Hemisphere climate.

6. Surface water cooled during the late Miocene, reaching cool to cold temperatures in the earliest Pliocene. The first icerafted material appeared after a short time of relatively warm surface waters close to the Miocene/Pliocene boundary. Prior to 2.5-2.6 Ma, ice-rafted material began to arrive at the Vøring Plateau in very small quantities, at irregular intervals, and usually for relatively short time spans. At $2.5-2.6 \mathrm{Ma}$ a major depositional phase of modest but consistent quantities of ice-rafted material began, lasting to approximately $1.2 \mathrm{Ma}$, at which time a rapid increase in the abundance of coarse ice-rafted detrital deposition occurred. The maximum concentrations of the icerafted material are found in sediments at about $0.4 \mathrm{Ma}$, and these concentrations decrease in the younger sediments.

7. Planktonic foraminifer distributions and oxygen-isotope data suggest that the increase in intensity of ice-rafted material deposition at 2.6 Ma was preceded by a long cold span with only discontinuous faunas and relatively little carbonate preserved. The highest diversities are found close to the transition from the uppermost Miocene to the Pliocene. The ensuing glacial development (during the Brunhes Chron) differed from the earlier one by showing indications of severe glaciations that were interrupted by few and short intervals of a warm-water influx into the Norwegian Sea. The warm-water influx reflects the young and episodic occurrence of the Norwegian Current.

8. Oxygen isotope ratios of the planktonic and benthic foraminifer shell material and sedimentological data (ice-rafted detritus, carbonate flux) suggest completely different climatic and oceanic regimes existed for the early part of the glacial history

Table 1. History of North Atlantic ice-rafting.

\begin{tabular}{|c|c|}
\hline Time (Ma) & Event \\
\hline 10.2 & $\begin{array}{l}\text { First occurrence of ice-rafted materials S of } \\
\text { Iceland (DSDP Site 408) }\end{array}$ \\
\hline $5.7-3.1$ & 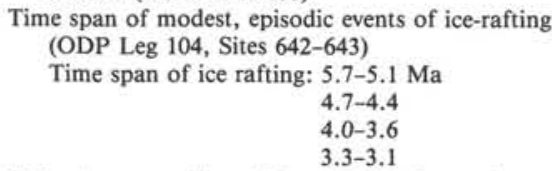 \\
\hline 2.6 & $\begin{array}{l}\text { Major increase of ice rafting, modest fluctuations, } \\
\text { virtually no "interglacials" }\end{array}$ \\
\hline $1.0-1.2$ & $\begin{array}{l}\text { Major increase of ice rafting, beginning of glacial- } \\
\text { interglacial mode }\end{array}$ \\
\hline 0.4 & $\begin{array}{l}\text { Late Quaternary peak events, much more impor- } \\
\text { tant than last glacial maximum }\end{array}$ \\
\hline$\sim 0.17$ & \\
\hline
\end{tabular}

of the eastern Norwegian Sea. Compared to the later part, the early history (2.6-1.2 Ma) was characterized by glacial environments, apparently with no clearly developed interglacials. During the time span between 1.2 and $0.6 \mathrm{Ma}$, oxygen isotope ratios grow considerably heavier than before. Subsequently, typical and regular fluctuations between glacials and interglacials reflecting $100-k . y$. cycles are observed in these cores.

9. The Neogene sedimentary sequences of Sites 642 and 643 have been interrupted by numerous, correlatable hiatuses. These suggest the repeated evolution of pulses of intensive bottom-water renewal leading to the erosion of the soft and organically rich sedimentary cover. In part they may correlate with the global hiatus record of Keller and Barron (1987).

10. Clay mineral distributions, pollen, and spores provide evidence for the Northern Hemisphere Paleogene and Neogene Quaternary climatic evolution. Close to the Paleocene/Eocene boundary, the climate was tropical to subtropical and moist, resulting in the formation of lateritic soils on the volcanic terrains. During the Paleogene and in particular the Neogene, the climate cooled first to temperate conditions and finally, toward the end of the Miocene and during the Pliocene, it achieved its glacial mode of variable intensity that has existed since.

\section{ACKNOWLEDGMENTS}

This synthesis of paleoenvironmental studies of ODP Leg 104 would not have been possible without the successful completion of the drill sites along the transect across the Vøring Plateau and the many specialized studies that have been carried out on the Paleogene, Neogene, and Quaternary sediments. R. Goll (Trondheim) provided a very detailed analysis of the partially highly divergent biostratigraphic zonations documented by the various specialists. Without a convincing solution of the stratigraphies of the sites, no attempt at a detailed description of the history of the Cenozoic Vøring Plateau environment could have been achieved.

This study was supported by the ODP support program of the German Research Foundation (Grant Th 200/3-1-4). We gratefully acknowledge the collaboration within the Kiel group, in particular, intensive help by Thomas Wolf, Helga Köhrer, Ortrud Runze, and Andrea VossHenneke. Reviews by R. Henrich, D. Spiegler (Kiel), and J. Baldauf (College Station) were most helpful.

\section{REFERENCES}

Aagaard, K., Swift, J. H., and Carmack, E. C., 1985. Thermohaline circulation in the Arctic Mediterranean Seas. J. Geophys. Res., 90: 4883-4846.

Barry, R. G., in press. The present climate of the Arctic Ocean and possible past and future states. In Herman, Y. (Ed.), The Arctic Seas.

Berggren, W., and Schnitker, D., 1983. Cenozoic marine environments in the North Atlantic and Norwegian-Greenland Sea. In Bott, M.H.P., Saxov, S., Talwani, M., and Thiede, J. (Eds.), Structure and Development of the Greenland-Scotland Ridge-New Methods and Concepts: New York (Plenum), 495-548.

Berggren, W. A., Kent, D. V., Flynn, J. J., and Van Couvering, J. A., 1985. Cenozoic geochronology. Geol. Soc. Am. Bull., 96:1407-1418.

Bolin, B., 1950. On the influence of the earth's orography on the general character of the westerlies. Tellus, 2:1894-1895.

Bohrmann, G., 1988. Zur Sedimentationsgeschichte von biogenem Opal im nördlichen Nordatlantik und dem Europäischen Nordmeer (DSDP/ODP-bohrungen 408, 642, 643, 644, 646 \& 647) [Ph.D. dissert.]. Math.-nat. Fak., KieI Univ., and Ber. Sonderforsch.-Ber. 313, 9:1-221.

Bott, M. H. P., Saxov, S., Talwani, M., and Thiede, J., 1983. Structure and Development of the Greenland-Scotland Ridge-New Methods and Concepts. New York (Plenum Press).

Bowen, D. O., and Sykes, G. A., 1988. Correlation of marine events and glaciations on the northeast Atlantic margin. Phil. Trans. R. Soc. London, B 318:619-635.

Brown, S., and Downie, C., 1984. Dinoflagellate cyst biostratigraphy of late Paleocene and early Eocene sediments from Holes 552, 553A, and 555, DSDP Leg 81 (Rockall Plateau). Init. Repts. DSDP, 81: Washington (U.S. Govt. Printing Office), 565-579. 
Carter, L. D.,. Brigham-Grette, J., Marincovich, L., Pease, V. L., and Hillhouse, J. W., 1986. The Cenozoic Arctic Ocean sea ice and terrestrial paleoclimate. Geology, 14:675-678.

CLIMAP Project Members, 1976. The surface of the ice-age Earth. Science, 191:1132-1137.

CLIMAP Project Members, 1981. Maps of northern and southern hemisphere continental ice, sea ice and sea surface temperatures in August for the modern and last glacial maximum. Geol. Soc. Am. Map Chart Ser., MC-36: Maps 7A and B.

Dalland, A., 1977. Erratic clasts in the lower Tertiary deposits of Svalbard-evidence of transport by winter ice. Norsk Polarinst. Aarbok, 1976: 151-165.

Dalland, A., Worseley, D., and Ofstad, K. (Eds.), 1988. A lithostratigraphic scheme for the Mesozoic and Cenozoic successions offshore mid- and northern Norway. Norw. Petrol. Direct. Bull. 14.

Donn, W. L., and Shaw, D. M., 1972. Discussion. In: Beneficial Modifications of the Marine Environment. Proceedings. Washington (National Academy of Sciences):49-61.

Ehrmann, W. U., and Thiede, J., 1985. History of Mesozoic and Cenozoic sediment fluxes to the North Atlantic Ocean. Contr. Sedimentol., 15.

Eldholm, O., Skogseid, J., Sundovor, E., and Myhre, A. M., 1989. The Norwegian-Greenland Sea. In Grantz, A., Johnson, G. L., and Sweeney, J. (Eds.), The Arctic Ocean Region, Vol. L. The Geology of North America: Boulder, CO (Geol. Soc. Am.).

Eldholm, O., Sundvor, E., Myhre, A. M., and Faleide, J. I., 1984. Cenozoic evolution of the continental margin off Norway and western Svalbard. Proc. Norw. Petrol. Soc. (North Europ. Margin Symp.): London (Graham and Totman), 3-18.

Eldholm, O., Thiede, J., Taylor, E., 1987. Evolution of the Norwegian continental margin: Background and objectives. In Eldholm, O., Thiede, J., Taylor, E., et al., Proc. ODP, Init. Repts., 104: College Station (Ocean Drilling Program), 5-25.

Eldholm, O., Thiede, J., Taylor, E., et al., 1987. Proc. ODP, Init. Repts., 104: College Station, TX (Ocean Drilling Program).

Funder, S., Abrahamsen, N., Bennike, O., and Feyling-Hanssen, R. W., 1985. Forested Arctic: Evidence from North Greenland. Geology, 13:542-546.

Gradstein, F. M., and Kaminski, M. A., in press. Taxonomy and biostratigraphy of new and emended species of Cenozoic deep-water agglutinated foraminifera from the Labrador and North seas. Micropaleontology.

Haq, B. U., Hardenbol, J., and Vail, P. R., 1987. Chronology of fluctuating sea levels since the Triassic. Science, 235:1156-1167.

Harwood, D. M., 1986. Do diatoms beneath the Greenland ice sheet indicate interglacials warmer than present? Arctic, 39:304-308.

Hempel, P., 1989. Der Einfluss von biogenem Opal auf die Bildung seismischer Reflektoren und die Verbreitung opalreicher Sedimente auf dem Vøring-Plateau [Ph.D. dissert.]. Math.-Naturw. Fak., Kiel Univ., FRG.

Henrich, R., Kassens, H., Vogelsang, E., and Thiede, J., 1989. The sedimentary facies of glacial/interglacial cycles of the Norwegian Sea during the last $350 \mathrm{ka}$. Mar. Geol., 86:283-319.

Jansen, E., Sjöholm, J., Bleil, U., and Erichsen, J. A., in press. Neogene and Pleistocene glaciations in the northern hemisphere and Miocene-Pliocene global ice-volume fluctuations: Evidence from the Norwegian Sea. In Bleil, U., and Thiede, J. (Eds.), Geologic history of Polar Oceans: Arctic vs. Antarctic. (Kluwer Acad. Publ.)

Kaminski, M. A., 1988. Cenozoic Deep-Water Agglutinated Foraminifera in the North Atlantic [Ph.D. dissert.]. Woods Hole/ Mass. Inst. Technol., MA.

Kanaya, K., and Koizumi, I., 1966. Interpretation of diatom thanatocoenosis from the North Pacific applied to a study of core V20-130 (Studies of the deep sea core V20-130, part IV). Tohoku Univ. Sci. Rep., Ser. 2, 37:89-130.

Keller, G., and Barron, J. A., 1987. Paleodepth distribution of Neogene deep-sea hiatuses. Paleoceanography, 2:697-713.

Keller, G., Herbert, T., Dorsey, R., D'Hondt, S., Johnsson, M., and Chi, W. R., 1987. Global distribution of late Paleogene hiatuses. Geology, 15:199-203.

Kellogg, T. B., 1975. Late Quaternary climatic changes in the Norwegian and Greenland Seas. In Weller, G., and Bowling, J. A. (Eds.), Climate of the Arctic. Proc. Alaska Sci. Conf., 24th: (Geophys. Inst., Univ. Alaska), 3-36.
1976. Late Quaternary climatic changes: Evidence from deepsea cores of Norwegian and Greenland Seas. Geol. Soc. Am. Mem., 145:77-110.

Koltermann, K. P., 1987. Die Tiefenzirkulation der Grönland-See als Folge des thermohalinen Systems des Europäischen Nordmeeres [Ph.D. dissert.]. Fachb. Geowiss., Hamburg Univ., FRG.

Krutzsch, W., 1966. Die sporenstratigraphische Gliederung des älteren Tertiärs im nördlichen Mitteleuropa (Paläozän- Mitteloligozän). $A b h$. zentr. geol. Inst., 8:112-149.

Lamb, H. H., 1972. Climate: Present, Past and Future. Vol. I. Fundamentals and Climate Now: London (Methuen).

Mackensen, A., Sejrup, H. P., and Jansen, E., 1985. The distribution of living benthic foraminifera on the continental slope and rise off southwest Norway. Mar. Micropaleontol., 9:275-306.

Manum, S. B., 1976. Dinocysts in Tertiary Norwegian-Greenland Sea sediments (Deep Sea Drilling Project Leg 38), with observations on palynomorphs and palynodebris in relation to environment. In Talwani, M., Udintsev, G., et al., Init. Repts. DSDP, 38: Washington (U.S. Govt. Printing Office), 897-919.

Meincke, J., 1983. The modern current regime across the GreenlandScotland Ridge. In Bott, M. H. P., Saxov, S., Talwani, M., and Thiede, J., Structure and Development of the Greenland-Scotland Ridge: New Methods and Concepts: London, New York (Plenum Press), 637-650.

Mosby, H., 1959. Deep water in the Norwegian Sea. Geofys. Publ., 21.

Mutter, J. C., Talwani, M., and Stoffa, P. L., 1984. Evidence for a thick oceanic crust adjacent to the Norwegian margin. J. Geophys. Res., $89: 483-502$.

Nilsen, T. H., and Kerr, D. R., 1978. Turbidites, red beds, sedimentary structures and trace fossils observed in DSDP Leg 38 cores and the sedimentary history of the Norwegian-Greenland Sea. In Talwani, M., Udintsev, G., et al., Init. Repts. DSDP, Suppl. 38-41: Washington (U.S. Govt. Printing Office), 259-288.

Ramm, M., in press. A stratigraphic study of the late Quaternary sediments on the Vøring Plateau, eastern Norwegian Sea. Mar. Geol.

Robin, G. de Q. (Ed.), 1983. The Climatic Record in Polar Ice Sheets: Cambridge, U.K. (Cambridge Univ. Press).

Ruddiman, W. F., and Raymo, M. E., 1988. Northern Hemisphere climate regimes during the past $3 \mathrm{Ma}$ : possible tectonic connections. Phil. Trans. R. Soc. London, B 318:411-430.

Schrader, H.-J., Bjørklund, R. R., Manum, S., Martini, E., and van Hinte, J., 1976. Cenozoic biostratigraphy, physical stratigraphy and paleoceanography in the Norwegian-Greenland Sea, DSDP Leg 38, paleontological synthesis. In Talwani, M., Udintsev, G., et al., Init. Repts. DSDP, 38: Washington (U.S. Govt. Printing Office), 11971211.

Sclater, J. G., Andersen, R. N., and Bell, M. L., 1971. The elevation of ridges and evolution of the central eastern Pacific. J. Geophys. Res., 76:7888-7915.

Shackleton, N. J., 1986. Paleogene stable isotope events. Palaeogeogr., Palaeoclimat., Palaeoecol., 57:91-102.

Slettemark, B., 1988. Paleoseanografiog paleoklima i Norskehavet de siste 2.8 mill. aar. Oksygen og karbonisotopanalyse av Leg 104 paa Vøringplataaet. Hovedfagsoppgave i maringeologi (Cand. Sci.) ved Universitetet i Bergen.

Streeter, S. S., Belanger, P. E., Kellogg, T. B., and Duplessy, J. C., 1982. Late Pleistocene paleooceanography of the Norwegian-Greenland Sea: Benthic foraminiferal evidence. Quatern. Res., 18:72-90.

Talwani, M., and Eldholm, O., 1977. Evolution of the NorwegianGreenland Sea: Recent results and outstanding problems. Geol. Soc. Am. Bull., 88:969-999.

Talwani, M., Udintsev, G., et al., 1976. Init. Repts. DSDP, 38: Washington (U.S. Government Printing Office).

Thiede, J., 1979. Paleophysiography of the North Atlantic and its surrounding epicontinental seas: Implications for North Atlantic and Arctic paleoceanography. Norw. Sea Symp. Oslo (Norw. Petrol. Soc.), NSS 4:1-24.

1988. Short term paleoclimatic variability: The cryosphere. Conf. Geosphere Fluctuations: Short Term Instabilities in the Earth System, Dec. 13-15, 1988, Hamburg. (Abstract)

Thiede, J., and Eldholm, O., 1983. Speculations about the paleodepth of the Greenland-Scotland Ridge during late Mesozoic and Cenozoic times. In Bott, M. H. P., Saxov, S., Talwani, M., and Thiede, J. (Eds.), Structure and Development of the Greenland-Scotland 
Ridge-New Methods and Concepts. New York (Plenum Press), 445-456.

Thiede, J., and Ehrmann, W. U., 1986. Late Mesozoic and Cenozoic sediment flux to the Central North Atlantic Ocean. Spec. Publ., Geol. Soc. London, 21:3-15.

Thiede, J., Spielhagen, R. F., and Weinelt, M. H., 1988. Cenozoic northern hemisphere paleoclimate: An enigma of correlation of oceanic and continental stratigraphic sequences. Meyniana, 40:47-53.

Thiede, J., Clark, D. L., and Herman, Y., in press. Late Mesozoic and Cenozoic Paleoceanography of the Northern Polar Oceans. The Ge- ology of North America, Vol. L, Boulder, CO (Geological Society of America).

Verdenius, J. G., and van Hinte, J. E., 1983. Central Norwegian-Greenland Sea: Tertiary arenaceous foraminifera, biostratigraphy and environment. In Proc., Workshop on Arenaceous Foraminifera 1st, 79 Sept., 1981. Continental Shelf Institute Publications, 108:173224.

Date of initial receipt: 19 January 1989

Date of acceptance: 11 May 1989

Ms 104B-190 